UNIVERSIDADE DE SÃO PAULO

PÓS-GRADUAÇÃO EM ESTÉTICA E HISTÓRIA DA ARTE

O PROJETO PERFORUM NO CONTEXTO DAS

COMEMORAÇÕES DOS 500 ANOS DO BRASIL

Thaís Thomaz Bovo

Orientação: Prof. Dr. Artur Matuck

São Paulo

2013 
THAíS THOMAZ BOVO

\title{
O PROJETO PERFORUM NO CONTEXTO DAS COMEMORAÇÕES DOS 500 ANOS DO BRASIL
}

\author{
Dissertação apresentada ao Programa \\ Interunidades em Estética e História da Arte da \\ Universidade de São Paulo, como exigência \\ parcial para a obtenção do título de Mestre em \\ Estética e História da Arte. \\ Linha de Pesquisa: Produção e Circulação de Arte \\ Orientador: Prof. Dr. Artur Matuck
}

São Paulo

2013 
AUTORIZO A REPRODUÇÃO E DIVULGAÇÃO TOTAL E PARCIAL DESTE TRABALHO, POR QUALQUER MEIO CONVENCIONAL OU ELETRÔNICO, PARA FINS DE ESTUDO E PESQUISA, DESDE QUE CITADA A FONTE.

\author{
Catalogação da Publicação \\ Biblioteca Lourival Gomes Machado \\ Museu de Arte Contemporânea da Universidade de São Paulo
}

BOVO, Thaís Thomaz.

O Projeto Perforum no contexto das comemorações dos 500 anos do Brasil / Thaís Thomaz Bovo; orientador: Artur Matuck. - São Paulo, 2013. 175 f.: il.

Dissertação (Mestrado - Programa de Pós-Graduação Interunidades em Estética e História da Arte) - Universidade de São Paulo, 2013.

1. Arte Digital - Século 20 - Brasil. 2. Telemática - Século 20 - Brasil. 3. Arte tecnológica - Século 20 - Brasil. 4. Estética da Comunicação. 5. Redes de Computadores. I. Matuck, Artur. II. Título.

CDD 700.105 
Nome: BOVO, Thaís Thomaz

Título: O Projeto Perforum no contexto das comemorações dos 500 anos do Brasil.

Dissertação apresentada ao Programa Interunidades em Estética e História da Arte da Universidade de São Paulo, como exigência parcial para a obtenção do título de Mestre em Estética e História da Arte.

Aprovada em:

Banca Examinadora

Prof. Dr. Instituição:

Julgamento: Assinatura:

Prof. Dr. Instituição:

Julgamento: Assinatura:

Prof. Dr. Instituição:

Julgamento: Assinatura: 


\section{AGRADECIMENTOS}

Este trabalho não seria possível sem a colaboração e estímulo de diversas pessoas. Gostaria de expressar toda a minha gratidão e apreço a todos aqueles que, direta ou indiretamente, contribuíram para que esta tarefa se tornasse uma realidade.

Ao professor Dr. Artur Matuck, por sua dedicação nos produtivos encontros de orientação, pelas inúmeras recomendações e pela cordialidade com que sempre me recebeu. A oportunidade que me ofereceu foi única e extraordinária. Obrigada!

Aos professores Dr. Milton Sogabe e Dra. Rejane Cantoni, por me receberem logo no início da pesquisa e pelas palavras esclarecedores.

Às professoras Dra. Carmen Aranha e Dra. Eliane Dias de Castro, por participarem da minha qualificação e pelas sugestões que mudaram o rumo da minha pesquisa.

À querida Renata Wrobleski, pela gravação da entrevista, pelas conversas e incentivos.

Ao Departamento de Relações Públicas, Propaganda e Turismo da ECA- USP, por permitir que a gravação da entrevista com Artur Matuck e Edson Oliveira fosse realizada.

Deixo meus agradecimentos também a todos que demonstraram carinho e que se alegraram comigo nesta etapa de minha vida. Amigos queridos, que nunca estiveram ausentes, agradeço-lhes pela amizade, incentivo, reflexões críticas e diálogos inspiradores. Muito obrigada a todos vocês: Vanessa Pereira, Priscilla Higashi, Natalicia do Nascimento, Irene Thomaz, Márcia Thomaz, Nilton Serra, Vinícius Rangel, Ines Alcaniz, Deborah Neves, Margareth Bevilacqua, Rosimeire Nery, Valeria Mota, Márcia Rodrigues, Fatima Ferianzzi, Roberta Toledo, Eliane Chicon, Maria Bragança e Edson Oliveira.

Aproveito para agradecer a cinco seres especiais, que me acompanham sempre e que tiveram grande relevância nesta pesquisa: meus cinco gatos, que me alegram e mostram que a vida deve ser experimentada curiosa e delicadamente.

Ao meu irmão Thiago, pela colaboração e carinho.

Aos meus pais, Maria e Luiz, pela sólida formação que me ofereceram, pela força, paciência e compreensão, mesmo nos momentos mais difíceis. 
Finalmente ao João Paulo, agradeço-lhe infinitamente por tudo! Pelo apoio, carinho, extrema paciência e pela presença incansável em todos os instantes. Enfim, por estar sempre ao meu lado.

Diante de tudo, posso dizer que foi uma experiência grandiosa, perturbadora e angustiante, mas também extremamente gratificante. 


\section{RESUMO}

A pesquisa consiste numa análise comparativa entre três eventos no contexto das comemorações dos 500 anos da chegada dos portugueses ao Brasil: uma mostra cultural em São Paulo, intitulada Bienal + 500; um ato oficial em Porto Seguro, onde foi assinado um Tratado de Cooperação e Amizade entre Brasil e Portugal e um projeto alternativo de arte e tecnologia denominado Projeto Perforum - este último concebido por Artur Matuck em colaboração com um grupo de artistas inovadores, que contestavam a representação eurocêntrica e triunfalista dos eventos oficialmente propostos. O Projeto Perforum pretendia envolver grupos étnicos e culturas que participaram do processo de formação da nação brasileira, buscando o diálogo entre elas. Por outro lado, em termos de linguagem artística, experimentavase com a Arte Telemática - compreendendo-se esta como a arte desenvolvida no eixo das telecomunicações, ou seja, aquela que ocorre da transmissão eletrônica de informações, pelo uso de telefones, equipamentos de fax, redes de computadores, televisão, satélites ou videoconferências.

Palavras-chave: arte telemática; 500 anos do Brasil; Projeto Perforum; diálogo de civilizações; telepresença. 


\begin{abstract}
This research aims to provide a comparative analysis of three events in the context of the celebrations of the 500th anniversary of the discovery of Brazil: A cultural exhibition in Sao Paulo, titled Bienal + 500, an official diplomatic act in Porto Seguro, where it was signed a Treaty of Friendship and Cooperation between Brazil and Portugal, and an alternative project of art and technology called Project Perforum the latter designed by Artur Matuck in collaboration with a group of innovative artists who challenged the triumphalist eurocentric officially proposed celebrations by the time. The Project Perforum intended to involve ethnic groups and cultures who participated in the process of formation of the Brazilian nation, intending a dialogical paradigm between these cultures. Moreover it proposed a series of experiments with the emerging telematic art - this being understood as the art developed in the sphere of telecommunication, that is, one that occurs while transmitting electronic information through the use of mobile equipment, fax, computer networks, television, satellites, or videoconferencing.
\end{abstract}

Keywords: Brazil 500 years; Perforum Project; dialogue of civilizations, video conferencing, telepresence. 


\section{LISTA DE FIGURAS}

Figura1: Mapa conceitual elaborado para a realização do projeto...................20

Figura 2: Eduardo Kac (2007) ............................................................33 Fonte:<http://www.ekac.org/osthoff.interview.art.es.html> Acesso em 25 de Setembro de 2013.

Figura 3: Roy Ascott, em 1992 .33

Fonte:<http://v2.nl/archive/people/roy-ascott> Acesso em 20 de Setembro de 2013.

Figura 4: Roy Ascott - Telenoia (folheto). 36

Fonte: $<$ http://v2.n1/events/telenoia> Acesso em 20 de Setembro de 2013.

Figura 5: Projeto City Portraits. 44

Fonte:<http://www.gilberttoprado.net/projetos/fax_arte/index.html> Acesso em 19 de Setembro de 2013.

Figura 6: Participantes do Projeto Reflux (1991-1992).

Fonte:<http://www.colabor.art.br/arturmatuck/portfolio/telecom_arts/reflux photos02.php $>$ Acesso em 19 de Setembro de 2013.

Figuras 7 e 8: Perforum Descobrimentos. 64 Fonte: Acervo pessoal Artur Matuck.

Figuras 9 e 10: Perforum Descobrimentos. 64 Fonte: Acervo pessoal Artur Matuck.

Figuras 11 e 12: Perforum Descobrimentos. 64

Fonte: Acervo pessoal Artur Matuck.

Figuras 13 e 14: Perforum Descobrimentos. 65 Fonte: Acervo pessoal Artur Matuck.

Figura 15: Desenho feito por uma menina da Espanha e enviado por fax a São Paulo... 65

Fonte: Acervo pessoal Artur Matuck.

Figura 16: Texto elaborado por uma menina de São Paulo e enviado por fax para Barcelona 66

Fonte: Acervo pessoal Artur Matuck.

Figura 17: Texto elaborado por um menino de São Paulo e enviado por fax a Barcelona. .66

Fonte: Acervo pessoal Artur Matuck.

Figura 18: Festa popular catalã. .67

Fonte: Acervo pessoal Artur Matuck. 
Figura 19: Participantes da Espanha .68 Fonte: Acervo pessoal Artur Matuck.

Figura 20: Grafite feito pelos participantes da São Paulo. 68 Fonte: Acervo pessoal Artur Matuck.

Figura 21: Um dos relógios fixados pela Rede Globo em diversas capitais do Brasil. 71 Fonte:<http://www.hansdonner.com/portuguese/watches/> Acesso em 19 de Setembro de 2013.

Figura 22: Logomarca oficial dos 500 anos do Brasil. Fonte:<http://www.brandprofiles.com/500-anos-do-descobrimento-do-brasil-logo $>$ Acesso em 19 de Setembro de 2013.

Figura 23: Nau Capitânia (réplica). 75

Fonte:<http://www.naval.com.br/blog/2009/08/30/nau-capitania-encontra-destino-no-espacocultural-da-marinha/\#axzz2fMQ5G8Fl> Acesso em 19 de Setembro de 2013.

Figura 24: Estudantes, indígenas, anarquistas e sem-terra tentam entrar em Porto Seguro 76

Fonte: $<$ http://arymoura.wordpress.com/2012/09/01/estado-pagara-indenizacao-de-r-10milhoes-por-reprimir-manifestacao-pacifica/> Acesso em 19 de Setembro de 2013.

Figura 25: Indígena a frente dos policiais que participam da operação em Porto Seguro. 76

Fonte:<http://www.radar64.com/ler.php?doc=13911> Acesso em 19 de Setembro de 2013.

Figura 26: A Primeira Missa no Brasil - de Victor Meirelles (1861). 79 Fonte:<http://pt.wikipedia.org/wiki/Ficheiro:Meirelles-primeiramissa2.jpg > Acesso em 19 de Setembro de 2013.

Figura 27: Índios participam da missa em comemoração aos 500 anos - Coroa Vermelha. 79 Fonte:<http://acervo.oglobo.globo.com/fotogalerias/comemoracoes-pelos-500-anos-dodescobrimento-do-brasil-9573462> Acesso em 19 de Setembro de 2013.

Figura 28: Mapa da exposição Bienal +500 no prédio da Bienal. 83 Fonte: QUAGLIATO, 2007, p. 98.

Figura 29: Artes Indígenas - Mostra do Redescobrimento. .85 Fonte: Capa do Catálogo - Brasil + 500 anos.

Figura 30: Negro de Corpo e Alma, Catálogo da Mostra do Redescobrimento Brasil +500 anos. 86

Fonte: Capa do Catálogo - Brasil + 500 anos.

Figura 31: Maria Madalena - de Francisco Xavier de Brito - século XVIII 
Fonte:<http://pastexhibitions.guggenheim.org/brazil/overview.html > Acesso em 20 de Setembro de 2013.

Figura 32: Peças da exposição "Brazil Body \& Soul" no Museu Guggenheim de Nova York. 88

Fonte:<http://pastexhibitions.guggenheim.org/brazil/overview.html> Acesso em 20 de Setembro de 2013.

Figura 33: Capa do CD vendido pelo Museu Guggenheim .88

Fonte: $<$ http://www.monstermarketplace.com/museum-cds/guggenheim-brazil-body-andsoul> Acesso em 20 de Setembro de 2013.

Figura 34: Perforum - Página de Acesso

Fonte: $<$ http://www.colabor.art.br/arturmatuck/portfolio/telecom arts/perforum mediadesign. php> Acesso em 20 de Setembro de 2013.

Figura 35: Lapsus Calami. 98

Fonte: Acervo pessoal Artur Matuck.

Figura 36: Lapsus Calami. 98

Fonte: Acervo pessoal Artur Matuck.

Figura 37: Lapsus Calami.

Fonte: Acervo pessoal Artur Matuck.

Figura 38: Mecanismos de Risco de Artur Matuck. Dia 26 de Junho de 2000 103

Fonte: Acervo pessoal Artur Matuck.

Figura 39: Mecanismos de Risco de Artur Matuck. Dia 26 de Junho de 2000. .103

Fonte: Acervo pessoal Artur Matuck.

Figuras 40 e 41: Índio xavante Hipahidi Top'tiro 104 Fonte: Acervo pessoal Artur Matuck.

Figuras 42: O Beijo do Cristal Líquido de Otávio Donasci. .104 Fonte: Acervo pessoal Artur Matuck

Figura 43: Morte como Mar de Yara Guasque 105 Fonte: Acervo pessoal Artur Matuck.

Figura 44: Metáfora LIBIDOECONOMIA, do grupo Interações Telemáticas. 105

Fonte:<http://www.udesc.br/perforum> Acesso em 25 de Setembro de 2013. 


\section{LISTA DE ABREVIATURAS E SIGLAS}

ANHEMBI-MORUMBI - Universidade Anhembi-Morumbi (SP)

ECA/USP - Escola de Comunicação e Artes da Universidade de São Paulo

PUC-SP - Pontifícia Universidade Católica de São Paulo

SSTV - Slow Scan Television

TELESC - Telecomunicações de Santa Catarina

UDESC - Universidade do Estado de Santa Catarina

UFSC - Universidade Federal de Santa Catarina

UNIVALI - Universidade do Vale do Itajaí

USP - Universidade de São Paulo 


\section{SUMÁRIO}

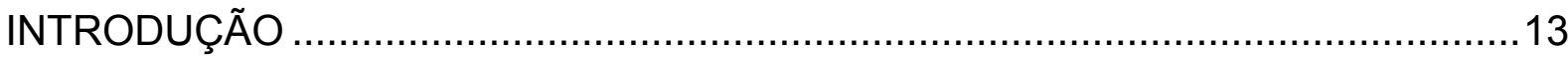

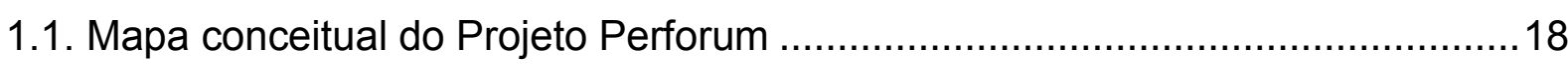

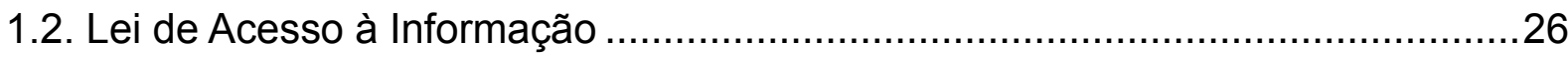

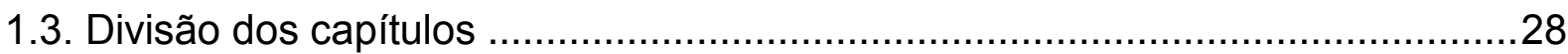

2. CONTEXTO HISTÓRICO CULTURAL: PROJETO PERFORUM NO CONTEXTO

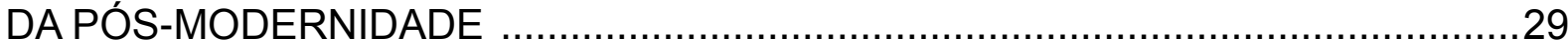

3. PROJETO PERFORUM CONTESTANDO OS 500 ANOS DO BRASIL .............45

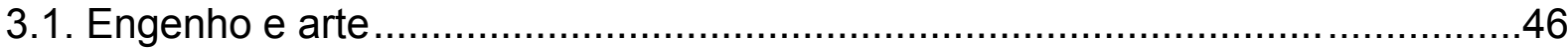

3.2. Diálogo de civilizações ................................................................ 48

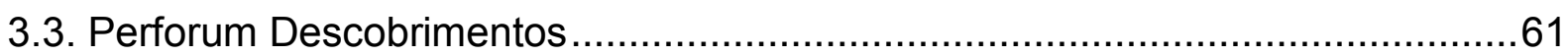

4. ANO 2000: AS COMEMORAÇÕES DOS 500 ANOS DO BRASIL .......................70

4.1. Comemorações dos 500 do Brasil em Porto Seguro - BA ..............................72

4.2. Resultado da Pesquisa à Lei de Acesso à Informação ..................................80

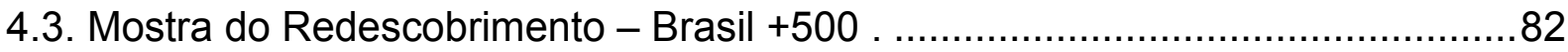

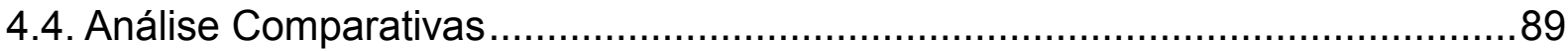

5. PROJETO PERFORUM - DESTERRO: ENSAIOS DE TELEPRESENÇA ...........91

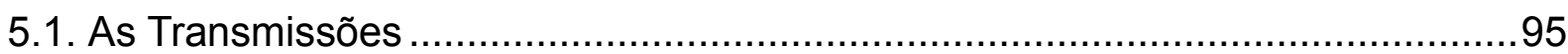

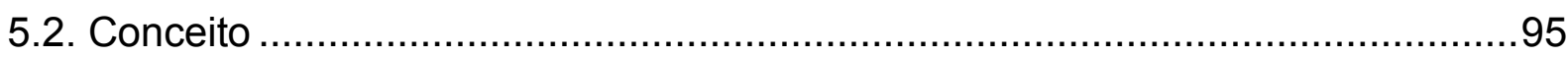

5.3. Descrições de algumas Teleleperformances ............................................... 96

5.4. Eventos de teletransmissão que ocorreram no Perforum Desterro ....................99

6. A QUESTÃO DA DOCUMENTAÇÃO E PRESERVAÇÃO DA ARTE TELEMÁTICA 106

6.1. A Documentação e a Preservação do Contexto Tecnológico ..........................108

6.2. Critérios de Preservação .................................................................... 109

6.3. Desafios e Propostas para a Preservação da Arte Telemática ......................... 110

6.4. Especificidades na Preservação da Arte Telemática .................................... 112

6.5. A Importância de Preservar e Documentar Eventos de Telearte ...................... 112

6.6. Como Preservar um Evento como o Projeto Perforum? ................................. 113

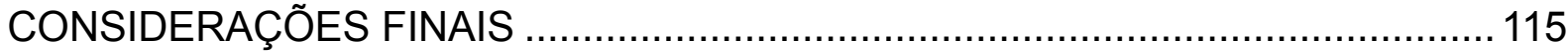

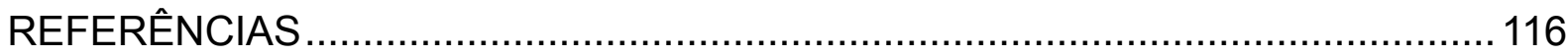

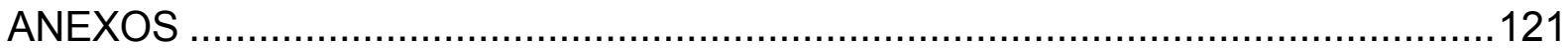

Projeto Perforum - Desenhando Fluxos de Informação e Conectando ...................122

Entrevista (transcrição) ....................................................................... 128

Tratado de Amizade, Cooperação e Consulta entre a República Federativa do Brasil e a República Portuguesa 
1.

INTRODUÇÃO

\author{
O artista criando e contextualizando \\ fenômenos e mensagens modelares sobe ao \\ espaço para de lá enviar sinais à Terra. \\ O artista como explorador do ser interior \\ continua o diálogo com o universo no espaço. \\ O artista como um poeta no limite \\ continua o diálogo com seu instrumental \\ sensório viaja ao espaço para ampliar a \\ perspectiva humana no 'novo mundo' - o céu \\ e o espaço. \\ $\mathrm{O}$ artista viaja entre mundos para colher \\ lendas e imagens conduzindo-as a muitos \\ lugares próximos e distantes ${ }^{1}$.
}

\footnotetext{
1 Manifesto de Arte Espacial - Otto Piene, Elizabeth Goldring e Lowry Burgess. Paris, 03 de
} Novembro de 1986. IN: Memorial, MATUCK, Artur, 2006, p. 54. 
O Projeto Perforum foi um evento de arte e tecnologia concebido e apresentado por Artur Matuck e sua equipe do Perforum em São Paulo, vinculados à Escola de Comunicações e Artes da Universidade de São Paulo; em colaboração com Yara Guasque e sua equipe do Perforum Desterro, vinculados ao Departamento de Artes Plásticas do Centro de Artes da Universidade de Santa Cararina, Florianópolis.

O Projeto Perforum tinha como subtítulo "Desenhando fluxos de informação e contactando culturas" ${ }^{2}$. É interessante notar como já se apresenta aqui dois focos temáticos em destaque: "os fluxos de informação" (tecnologia) e "conectando culturas" (diálogo de civilizações). São temas que estavam em grande evidência naquela época. O primeiro dizia respeito à introdução das ditas "novas tecnologias", ou seja, a disseminação da telemática. Quanto ao segundo, o momento do pós Guerra Fria, chamava atenção para novos temas internacionais como o póscolonialismo.

\begin{abstract}
Acho que a ideia era contestar os próprios 500 anos. Essa noção mítica de que Portugal descobriu o Brasil. De que o Brasil só existe por causa de Portugal. É como o beijo que o príncipe dá para a princesa, não é? Eu acho isso interessante essa estória de que nos contos de fadas a mulher só começa a existir quando o homem surge, de outro modo a mulher esta num sono eterno, ela não tem identidade, não tem existência, é o homem que faz o toque mágico e a mulher começa a existir. Então não sei, existe uma mitologia de que o Brasil existe por causa de Portugal. De que Portugal descobriu o Brasil ${ }^{3}$. (Matuck - entrevista).
\end{abstract}

Assim, no contexto das comemorações dos 500 anos do Brasil, o Projeto Perforum pretendia envolver grupos étnicos e culturas que participaram do processo de formação da nação brasileira, buscando estabelecer o diálogo entre essas diversas culturas, com o auxílio das "novas tecnologias" em evidência na época, retomando as discussões levantadas pelos modernistas nos anos 1920.

Então acho que tinha essa ideia, que era uma ideia utópica também,

\footnotetext{
${ }^{2}$ Projeto Perforum - está ao final, em anexo.

${ }^{3}$ Entrevista realizada em 04 de Abril de 2013 no Departamento de Relações Públicas, Propaganda e Turismo da ECA- USP. A autora da entrevista foi Thaís Thomaz Bovo e os entrevistados foram Artur Matuck e Edson de Oliveira. Houve a participação especial de Renata Wrobleski, que foi a responsável pala gravação. A transcrição integral da entrevista está ao final da dissertação, em anexo.
} 
de autonomia do Brasil, e recentemente eu li sobre essa questão, do Oswald de Andrade. Ele vai refundar o Brasil através da deglutição do Bispo Sardinha. Eu acho uma coisa interessantíssima o que ele faz, ele funda um movimento artístico cultural, intelectual, nacionalista, chamado Antropofagia, ele fala que o Brasil na verdade se inicia quando os índios Caetés deglutem um bispo português, e recentemente eu estava estudando isso e eu descobri que essa estória pode ser simplesmente uma farsa, que existem depoimentos que dizem que quem matou o bispo Sardinha foram os próprios portugueses, e eles além de matar o bispo português, eles resolveram culpar os índios brasileiros, que não tinham nada a ver com a estória, porque culpando os índios brasileiros, os chamados Caetés do Ceará, poderia haver uma razão para que os portugueses tomassem conta da terra dos índios Caetés. Porque eles seriam considerados como índios assassinos, antropófagos. Então, haveria uma razão para que eles fossem destituídos de sua propriedade. Isso daí, assim, não sei o que o Oswald de Andrade pensaria disso. (Matuck - entrevista).

No olhar de hoje, as discussões do passado adquirem uma nova conotação. O Projeto Perforum talvez não tivesse essa percepção na época, mas tal qual as ideias dos modernistas, a proposta inicial do Projeto poderia se desdobrar em pontos de vista inusitados.

Que a deglutição do Bispo Sardinha seria uma farsa. Mas acho que mantém esse sentido simbólico, aliás, não sei por que a gente não usou isso no Projeto Perforum, a gente podia fazer a última pergunta do novo Perforum acho que devia incluir isso, a não deglutição do Bispo Sardinha pelos índios Caetés. Agora, eu não sei, acho que a principal diferença seria essa de falar: "vamos ouvir o índio, vamos ouvir o negro e não só o branco". A nação brasileira tem essas três etnias que se cruzam e que constroem o Brasil que a gente conhece, e por que os 500 anos da descoberta do Brasil pelos portugueses? Por que não a descoberta do Brasil pelos índios, pelos negros? Então essa era a ideia, e essa era a principal diferença. (Matuck entrevista).

O fato é que a proposta do Projeto Perforum estava perfeitamente situada em sua época. As linguagens artísticas do período estão sobre o impacto do advento das novas tecnologias digitais e das intervenções performáticas. Assim, em termos de linguagem artística, experimentava-se com a Arte Telemática - compreendendose esta como a arte desenvolvida no eixo das telecomunicações, ou seja, aquela que ocorre da transmissão eletrônica de informações, pelo uso de telefones, equipamentos de fax, redes de computadores, televisão, satélites ou videoconferências. 
Sendo aprovado pela Pró-Reitoria de Cultura e Extensão Universitária para participar oficialmente das comemorações na USP dos 500 anos do Brasil, o Projeto Perforum estava perfeitamente contextualizado também localmente.

Quanto ao uso das novas tecnologias aplicadas às artes, "A fundamentação teórica do Projeto Perforum segue um conceito de autoria em criação mediática desenvolvida em obras contemporâneas de arte e tecnologia" ${ }^{4}$. O que Artur Matuck propõe é a criação de um "metatexto" com auxílio das tecnologias digitais então disponíveis, "os trabalhos a serem realizados seguirão diretrizes pré-determinadas de ordem processual, conceitual, tecnológica e computacional, que constituem o metatexto" 5 .

A partir daí, o processo desencadeado transforma o autor da obra de arte em um "meta-autor". Uma vez que o metatexto por ele construído "tem, portanto, a função de orientar atos performáticos de expressão estética, procedimentos de organização de informações, processos generativos de sequências significantes ou sistemas de produção co-autorada" 6 .

Ele explica os conceitos envolvidos: "Neste processo autoral, o criador atua inicialmente como 'meta-autor', concebendo o 'metatexto' em sua forma definitiva. Posteriormente, como artista procedimental, o mesmo autor ou os coautores produzem o trabalho, isto é, escrevem o texto, seguindo o projeto metatextual" 7 .

O Projeto Perforum preocupava-se, assim, com uma metodologia de uso das novas tecnologias. Fato pouco comum naquela época, que fascinada com a introdução e o impacto pelas novidades tecnológicas, esquecia-se de que "novas tecnologias" demandam novos métodos. Como colocado na apresentação do Projeto:

Este tem sido um processo inédito e mesmo imprevisível. O planejamento interativo de eventos de teletransmissão não tem ainda um cânone estabelecido de regras e procedimentos. Portanto, a experiência do Perforum neste campo abre perspectivas para o estabelecimento desta linguagem metatextual interativa, na qual os grupos distantes conduzem, previamente às telecomunicações, reuniões presenciais ou telepresenciais preparatórias, visando ao

\footnotetext{
${ }^{4}$ Texto elaborado por Artur Matuck, no qual anuncia as diretrizes do Perforum - intitulado Projeto Perforum-Desenhando Fluxos de Informação e Conectando Culturas (em anexo).

5 Idem.

${ }^{6}$ lbidem.

7 Ibidem.
} 
planejamento e roteirização das conexões ${ }^{8}$.

No outro viés temático, isto é, no contexto cultural, "o Projeto Perforum visa integrar telecomunicação, design, educação, artes plásticas e performance, na realização de um evento telemático intercultural de longa duração congregando indivíduos, artistas, escritores, teóricos e humanistas brasileiros, índios, europeus, africanos e americanos".

A comemoração dos 500 anos do Brasil serve, então, como pretexto para uma reflexão sobre o diálogo entre as culturas implícitas na formação da nação brasileira. "Seu conceito fundamental é o da interação dialógica entre criadores, indivíduos, intelectuais, representantes de países, regiões, etnias e culturas distantes que participaram do movimento das Navegações, da Constituição Étnica e Cultural das Américas e especialmente do Brasil" 9 .

E observamos que o Projeto Perforum pretende somar os dois pólos temáticos: "Perforum propõe que a reflexão constitutiva e estética acerca do entrechoque cultural da Conquista se manifeste, na atualidade, também no descobrimento do ciberespaço. A celebração do processo histórico das Navegações se dará no presente, através da interação cultural marcada pela telecomunicação, pela telepresença, pela arte interativa e pelos processos de autoria coletiva" ${ }^{10}$.

No mesmo sentido propunha-se a "processos digitais" com eventos "físicos e geográficos": "Perforum se estrutura a partir de ações virtuais, pedagógicas, telemáticas, combinadas entre si, visando integrar processos digitais com eventos localizados no contexto físico e geográfico" ${ }^{11}$.

Em síntese, entre os objetivos apontados pelo Projeto Perforum (anexo), destacam-se três:

a) Proporcionar intercâmbio de ideias, conceitos e posicionamentos, buscando a difusão cultural, o conhecimento mútuo, e a valorização do Outro.

b) Manifestar linguagens da arte que investigam a intenção dinâmica entre agentes humanos, processos computacionais e tecnologias de telecomunicações.

c) Desenvolver a metalinguagem dos processos cooperativos do ciberespaço, dos sistemas interativos, dos projetos de comunicação,

\footnotetext{
8 Ibidem.

9 Ibidem.

10 lbidem.

11 Ibidem.
} 
e da reengenharia social.

Com relação ao contexto dos 500 anos do Brasil, contraposto ao diálogo de civilizações, temos a proposição: "A chegada do europeu na América, marcada por conflitos étnicos, políticos e religiosos, resulta em coexistência e diversidade cultural, deflagrando um processo histórico atuante ainda sendo experienciado e interpretado" 12 .

Nem todos os propósitos foram realizados por uma série de razões que serão discutidas ao longo desse trabalho, no entanto, eram esses os conceitos sobre o qual o Projeto Perforum se fundamentava; bem diferente, aliás, de outras propostas de comemoração oficialmente apoiadas e que tiveram lugar na ocasião.

\subsection{MAPA CONCEITUAL DO PROJETO PERFORUM}

Para auxiliar na visualização das ideias de um evento tão complexo como o Projeto Perforum, foram usados Mapas Conceituais, que são "representações gráficas semelhantes a diagramas, que indicam relações entre conceitos ligados por palavras. Representam uma estrutura que vai desde os conceitos mais abrangentes até os menos inclusivos. São utilizados para auxiliar a ordenação e a sequenciação hierarquizada dos conteúdos" ${ }^{13}$.

O uso desse tipo de recurso faz sentido no âmbito de um projeto que tem como parâmetro as tecnologias digitais. Além disso, "esta abordagem dos mapas conceituais está embasada em uma teoria construtivista, entendendo que o indivíduo constrói seu conhecimento e significados a partir da sua predisposição para realizar esta construção" (Idem), relacionado também à proposta de expansão do conhecimento implícita no Projeto Perforum.

Concept mapping is a technique for representing knowledge in graphs. Knowledge graphs are networks of concepts. Networks consist of nodes (points/vertices) and links (arcs/edges). Nodes represent concepts and links represent the relations between concepts. Concepts and sometimes links are labeled. Links can be non-, uni- or bi-directional. Concepts and links may be categorized,

\footnotetext{
${ }^{12}$ Ibidem.

13 Mapas Conceituais, disponível em: http://penta2.ufrgs.br/edutools/mapasconceituais/ - Acesso em 07 de Junho de 2013.
} 
they can be simply associative, specified or divided in categories such as causal or temporal relations ${ }^{14}$.

Nesse trabalho foi utilizada a técnica de mapas conceituais desenvolvida na Cornell University pelo professor Joseph D. Novak, denominada Mind Mapping. Este pesquisador concluiu que "Meaningful learning involves the assimilation of new concepts and propositions into existing cognitive structures". ${ }^{15}$ Tony Buzan, por sua vez, desenvolveu o sistema "Mind Mapping" descrevendo o processo como: "a mind map consists of a central word or concept, around the central word you draw the 5 to 10 main ideas that relate to that word. You then take each of those child words and again draw the 5 to 10 main ideas that relate to each of those words" (Idem).

A imagem a seguir representa o mapa conceitual criado para ajudar na formulação inicial desta pesquisa:

14 http://users.edte.utwente.nl/lanzing/cm_home.htm. Acesso em 07 de Junho de 2013.

15 Idem. 


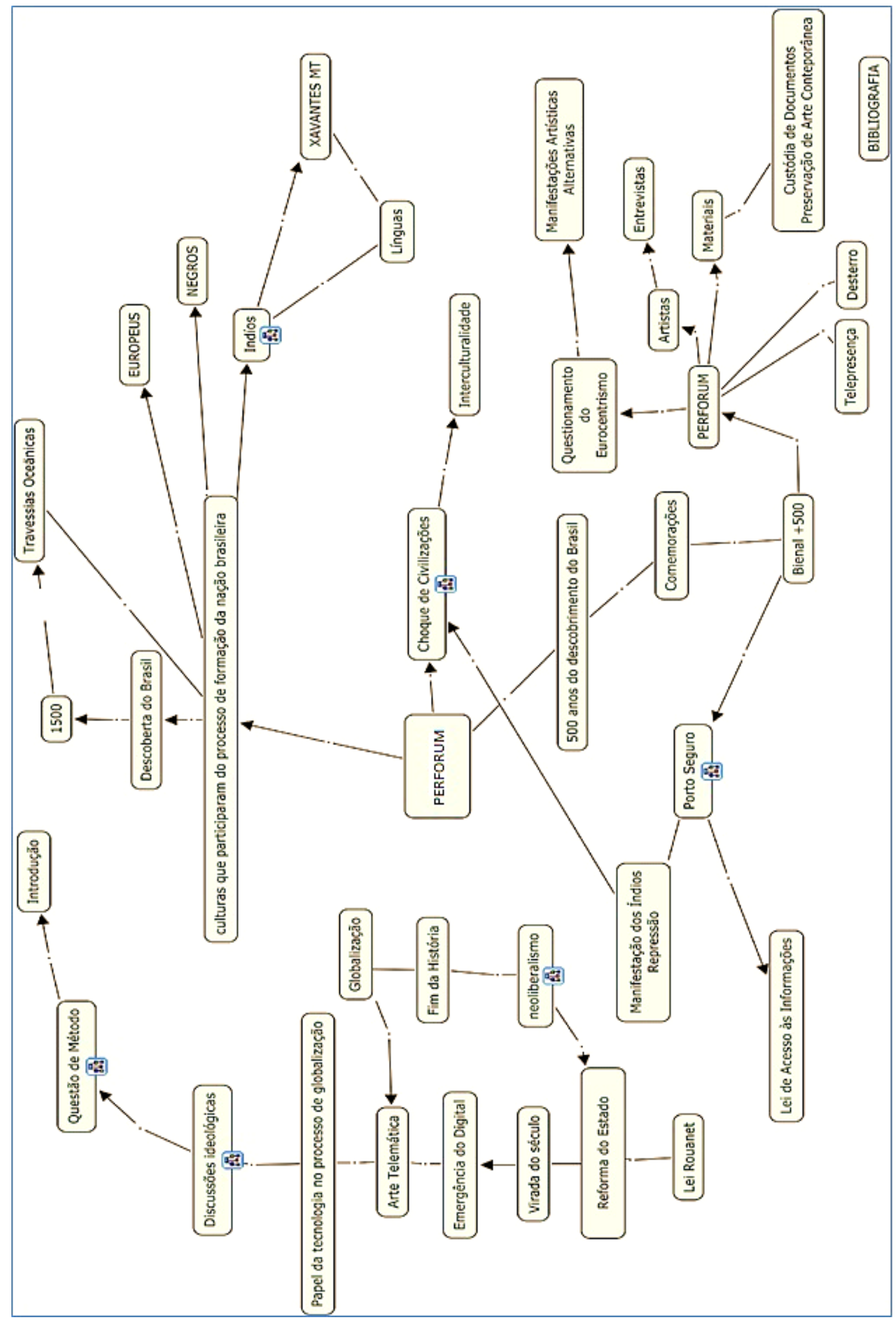

Figura 1: Mapa conceitual elaborado para a realização do projeto - foi utilizado o programa Cmap, específico para a criação de mapas conceituais e que está disponível em www.cmap.ihmc.us. 
Portanto, no âmbito da pesquisa, o Projeto Perforum está contextualizado num mapa conceitual que engloba uma série de palavras-chave que se distribuem em três eixos conceituais:

\section{Linha do tempo}

1500 - Carta do escrivão português Pero Vaz de Caminha, comemorações, travessias oceânicas.

1922 - Movimento Modernista que celebrou as três raças formadoras do Brasil.

1989 - Queda do Muro de Berlim, "Fim da História”, Globalização, Neoliberalismo.

1998 - Lançamento do Projeto Perforum - 500 anos.

2000 - Comemorações dos 500 anos do Brasil, Projeto Perforum Desterro.

2001 - Queda das Torres Gêmeas, "Choque de civilizações".

\section{Contexto cultural}

Culturas participantes na formação do Brasil, europeus, índios e negros.

Choque de civilizações, conflitos entre brancos e índios, interculturalidade.

Projeto Perforum, Bienal + 500, Comemorações em Porto Seguro, manifestação dos índios, repressão.

\section{Interatividade e telepresença}

Arte telemática - manifestações artísticas alternativas, telepresença.

Projeto Perforum Desterro - materiais, artistas.

Preservação da arte contemporânea - custódia de documentos, materiais, artistas, entrevistas.

A partir deste mapeamento pode-se realizar uma análise comparativa entre eventos ocorridos no contexto das comemorações dos 500 anos do Brasil. Para tanto, foram escolhidos três eventos em especial: uma mostra cultural em São Paulo, intitulada Bienal + 500; um ato oficial em Porto Seguro, onde foi assinado um "Tratado de Amizade, Cooperação e Consulta, entre a República Federativa do Brasil e a República Portuguesa" (em anexo) e um projeto alternativo de arte e tecnologia denominado Projeto Perforum, este último concebido por Artur Matuck em 
colaboração com um grupo de artistas inovadores, que contestavam a representação eurocêntrica e triunfalista dos eventos oficialmente propostos.

Com auxílio da análise comparada foi possível explorar o potencial inovador das tecnologias eletrônicas aplicadas às manifestações artísticas. Buscou-se também situar o contexto histórico em que emergiram essas novas possibilidades: a globalização e o momento unipolar; a disseminação de novas tecnologias, culminando com as comemorações dos 500 anos da chegada dos portugueses ao Brasil.

O destaque recairá sobre a proposta do Projeto Perforum, que questionava conceitualmente o teor eurocêntrico e triunfalista presente na maioria das comemorações ocorridas no período.

O Projeto diferenciou-se das demais propostas de eventos ao propor uma reflexão teórica e estética sobre o encontro histórico de diferentes culturas que contribuíram para a formação da nação brasileira - ao mesmo tempo em que apresenta uma linguagem inovadora, envolvendo experimentos de telepresença.

Além de refletir sobre o tema, a pesquisa buscou, também, apontar maneiras de resgatar e preservar a memória de manifestações artísticas que têm como base o meio eletrônico. Assim, buscou-se apontar maneiras de preservar este evento de Arte Telemática, que se destaca pelo seu papel reflexivo e questionador e pelo uso inovador das tecnologias emergentes.

A respeito da globalização naquele momento histórico analisado - ano 2000 -, que se caracteriza pela aceleração do tempo presente, Milton Santos aponta:

Pode-se dizer que a velocidade assim utilizada é duplamente um dado da política e não da técnica. De um lado trata-se de uma escolha relacionada com o poder dos agentes e, de outro, da legitimação dessa escolha, por meio da justificação de um modelo de civilização. É nesse sentido que estamos afirmando tratar-se mais de um dado da política que, propriamente, da técnica, já que esta poderia ser usada diferentemente em função do conjunto de escolhas sociais. De fato, o uso extremo da velocidade acaba por ser o imperativo das empresas hegemônicas e não das demais, para as quais o sentido de urgência não é uma constante. Mas é a partir desse e de outros comportamentos que a política das empresas arrasta a política dos Estados e das demais instituições supranacionais ${ }^{16}$.

\footnotetext{
${ }^{16}$ SANTOS, Milton - Por uma outra globalização: do pensamento único à consciência universal, Rio de Janeiro, Record, 2009, p. 122.
} 
No âmbito do projeto, foi realizada numa interação entre o grupo do Projeto Perforum e índios xavante, na pessoa do líder indígena Hiparidi Top'tiro. O interessante é que esses índios também buscavam na época estabelecer contatos com a sociedade brasileira, como se evidencia nas muitas publicações de textos de origens étnicas, como é o caso do "Mito e História do Povo Xavante", prefaciado por Ailton Krenak, em abril de 1998:

Mas o mundo está perdendo o contato com o Poder Criador da Palavra e se afastando da sua memória divina que dá origem a todas as coisas. Para este mundo, sem a Palavra Verdadeira, Palavra Criadora, o que resta é a vertigem virtual. Mundo virtual onde as palavras não criam, onde a palavra vende ideias e conceitos. Onde a palavra é coisa! Ouça a Palavra dos velhos sábios, eles carregam a Palavra Cântaro, de onde jorra a água pura e vital. Estas, as Palavras Criadoras, têm seus Guardadores no meio da nossa gente antiga, nossos velhos. Em alguns lugares da Terra ainda vivem essas pessoas que guardam e vigiam a Palavra Criadora. Um desses lugares é aqui mesmo! Ouça a Palavra dos A'uwê que vivem na aldeia Etêñiritipa, perto do rio das Mortes, em Mato Grosso. Eles estão trazendo a Palavra Criadora, do tempo em que as coisas, como as conhecemos hoje, se faziam... Estão partilhando sua lembrança da Criação com todos nós. Lembrando que somos filhos da Terra e que devemos respeito à Palavra Criadora ${ }^{17}$.

Nessa mesma época, como parte inicial do Projeto Perforum, foi organizada uma vivência com esses índios xavante, onde se ensinava a dança e a pintura corporal características da cultura xavante. Também houve a proposta de um vídeo sobre essa interação, porém por falta de recursos o material acabou se perdendo.

Depois disso e da passagem das comemorações dos 500 anos do "Descobrimento", o Projeto Perforum veio a evoluir com novas propostas de telepresença. Instituiu-se inclusive um projeto paralelo que seria denominado "Perforum Desterro" com base em Florianópolis, porém nossa reflexão pretende focalizar mais o momento da virada do século XX para o século XXI, como crucial na experiência humana, ainda muito pouco estudado.

Eric Hobsbawn, na Era dos Extremos, em seu capítulo sobre o Terceiro Milênio, faz referência ao lugar do Terceiro Mundo, quando diz: "Yet it had become increasingly clear over the last half of the Short Twentieth century that the First World could win battles but not war against the Third, or rather that winning wars, even if

\footnotetext{
${ }^{17}$ KRENAK, Ailton. WAMRÊMÉ ZA'RA. Mito e História do Povo Xavante: Nossa Palavra. São Paulo. Editora Senac, 1998.
} 
possible, could not guarantee control of such territories" ${ }^{18}$.

Com auxílio da análise comparada, explorou-se o potencial inovador das tecnologias eletrônicas aplicadas às manifestações artísticas. Buscou-se também situar o contexto histórico em que emergiram essas novas possibilidades: a globalização, o momento unipolar e o neoliberalismo; a disseminação de novas tecnologias e as comemorações dos 500 anos da "descoberta" do Brasil.

Nosso recorte temporal será os anos 1989, culminando com a virada do século. O período foi marcado por discussões ideológicas polarizadas em torno da pós-modernidade e final da História. Como em caixa de ressonância, no Brasil se discutia a reforma total do Estado, propondo-se o seu encolhimento. Segundo o historiador Francisco Carlos Teixeira da Silva, a proposta do Estado Mínimo, ou seja, do neoliberalismo no Brasil:

remonta ao início dos anos 20, quando a intervenção do Estado nas questões sociais era, quase sempre, armar a polícia contra as greves. Ao mesmo tempo, afastando o Estado como elemento regulador, volta-se para o mercado, visto de forma quase religiosa, como único mecanismo e critério de regulação econômica. Face ao caráter exíguo do mercado interno, ainda mais quando desprotegido, oferecem-se os mercados mundiais através da incorporação à globalização, ao livre fluxo de capitais, serviços e mercadorias. Estas são transformações em curso, de vulto planetário, apontando para uma nova forma de organização social e econômica do capitalismo. Será no bojo de tais transformações, sem ainda resolver aquelas herdadas de um tempo anterior, que o Brasil fará sua entrada no século $X X I^{19}$.

Sobre o mesmo tema, o pesquisador, geógrafo e professor Milton Santos manifestava o seu ponto de vista inovador:

O discurso que ouvimos todos os dias para nos fazer crer que deve haver menos Estado, vale-se dessa mencionada porosidade [quando o território deixa de ter fronteiras rígidas, levando ao enfraquecimento e à mudança de natureza dos Estados nacionais], mas sua base essencial é o fato de que os condutores da globalização necessitam de um Estado flexível aos seus interesses. As privatizações são a mostra de que o capital se tornou devorante, guloso ao extremo, exigindo sempre mais, querendo tudo. (...) o Estado acaba por ter menos recursos para tudo o que é social, sobretudo no caso das privatizações caricatas, como no modelo brasileiro, que financia as empresas estrangeiras candidatas à compra do capital social nacional. Não é que o Estado se ausente ou

${ }^{18}$ HOBSBAWN, Eric. The age of extremes. New York: Vintage Books, 1994, p. 562.

19 SILVA, Francisco Carlos Teixeira da. Brasil, em direção ao século XXI. In: LINHARES, Maria Yedda. (Coord.). História geral do Brasil. 9. ed. Rio de Janeiro: Elsevier, 2000, p. 419 e 420. 
se torne menor. Ele apenas se omite quanto ao interesse das populações e se torna mais forte, mais ágil, mais presente, ao serviço econômico dominante ${ }^{20}$.

Já na percepção do Professor Samuel Pimenta Guimarães:

O livre jogo das forças de mercado em um mercado oligopolizado leva a uma ainda maior concentração de renda e de riqueza e a uma maior influência do poder econômico sobre a política; o livre jogo de forças sociais de poder em extremo desigual leva à concentração de poder em favor de velhas e novas oligarquias (... ${ }^{21}$.

Em termos de pesquisa de campo, foram estabelecidos contatos com os artistas que participaram do evento e contribuíram criativamente para a realização do Projeto Perforum - esses depoimentos e entrevistas elucidaram diversos aspectos que podem ter passado despercebidos naquele momento; como se observa na entrevista realizada com o autor do projeto.

Sabemos que a obsolescência funcional, junto à dependência de sistemas técnicos incompatíveis, representam grandes ameaças à preservação da memória artística brasileira, especialmente de obras que fogem a formatos tradicionais e que recorrem à utilização de mídias eletrônicas. Estas são questões fundamentais para a custódia de documentos históricos contemporâneos, concernentes a obras e eventos imateriais, de formas culturais que escapam aos formatos tradicionais - do chamado patrimônio imaterial.

Além disso, a pesquisa e suas conclusões podem servir como fundamento para áreas correlatas, tais como performances, instalações, intervenções urbanas, gêneros que se caracterizam na maior parte de suas obras pela efemeridade. Por esta razão, seu desenvolvimento se justifica e sua contribuição deve ser valiosa.

A pesquisa teve como objetivo analisar comparativamente as propostas de eventos para a comemoração dos 500 anos de descobrimento do Brasil. Para tanto foi indispensável o referencial histórico do período 1989-2001, assim como os depoimentos de participantes do Projeto Perforum e o resgate dos materiais e registros sobre o Projeto Perforum. A partir daí tornou-se possível refletir sobre a problemática e possíveis soluções para o registro documental da Arte Telemática e

\footnotetext{
${ }^{20}$ SANTOS , Milton - Por uma outra globalização: do pensamento único à consciência universal, Rio de Janeiro, Record, 2009, p 66.

${ }_{21}$ GUIMARÃES, Samuel Pinheiro. Desafios Brasileiros na Era dos Gigantes, Rio de Janeiro: Contraponto, 2005, p. 264.
} 
estratégias que poderão ser adotadas.

Essa pesquisa pretende resgatar e analisar o Projeto Perforum como manifestação artística alternativa, no contexto das comemorações dos 500 anos do Brasil.

A metodologia aplicada à pesquisa tem caráter qualitativo ${ }^{22}$ e desenvolveu-se a partir do conhecimento do Projeto Perforum, uma série de eventos telemáticos realizados entre os anos de 1999 a 2001, bem como de análises de referências bibliográficas, conversas e coleta de depoimentos de participantes, artistas e colaboradores que estiveram envolvidos na realização do evento, tais como: Artur Matuck, Yara Guasque, Naira Ciotti, Hiparidi Top'tiro, Paula Perissinotto, Beatriz Bianco, Otávio Donasci, Edson de Oliveira, entre outros.

\subsection{LEI DE ACESSO À INFORMAÇÃO}

Numa tentativa de aprofundar as fontes primárias, buscou-se a utilização da lei de Acesso à Informação Pública, disciplinado pela Lei Federal no. 12.527 de 18 de novembro de 2011 e regulamentado pelo Decreto no. 7724, de 16 de maio de 2012. Essa Lei garante o direito fundamental de acesso à informação, prevendo que informações de interesse coletivo ou geral deverão ser divulgadas de ofício pelos órgãos públicos, independente de solicitações. A Lei, no entanto, estabelece diretrizes a serem seguidas para garantir os princípios básicos da Administração Pública e procedimentos específicos que devem ser observados pelos órgãos e entidades no âmbito dos três Poderes do Estado (Executivo, Legislativo e Judiciário) em todas as suas esferas (federal, estadual e municipal).

A finalidade desta Lei é assegurar o direito fundamental de acesso à informação. De tal forma, a Lei dispõe que órgãos e entidades do Poder Público devem assegurar:

- a gestão transparente da informação, propiciando amplo acesso a ela e sua divulgação;

- a proteção da informação, garantindo-se sua disponibilidade, autenticidade e integridade;

${ }^{22}$ Caracterizada por ser uma pesquisa onde são desenvolvidos conceitos e compreensões a partir dos padrões encontrados nos dados ou nos estudos de caso, ao invés de coletar dados para comprovar teorias anteriormente concebidas. 
- a proteção da informação sigilosa e da informação pessoal, observada a sua disponibilidade, autenticidade, integridade e eventual restrição de acesso.

Um exemplo de informação pública obtida por meio da Lei foi realizado em 04 de Janeiro de 2013, no portal da Lei de Acesso à Informação ${ }^{23}$.

Com auxílio dessa ferramenta, pretende-se esclarecer certos fatos contemporâneos ao Projeto Perforum. É o caso, por exemplo, das comemorações dos 500 anos do Descobrimento do Brasil, que se realizaram na cidade baiana de Porto Seguro em 22 de abril de 2000. Com amplo apoio oficial, o evento foi polêmico na ocasião pela forma que foi conduzido, desrespeitando os direitos humanos dos manifestantes, índios e trabalhadores sem terra.

Relembramos que, na mesma época, o Projeto Perforum teve a sua implementação grandemente prejudicada pela falta de recursos. Algumas propostas de apoio foram tentadas, inclusive o apoio através da Lei Rouanet, mas os meandros burocráticos acabaram desmotivando a busca dos incentivos fiscais. Nesse contexto, consideramos de grande interesse levantar algumas questões como: por que um projeto tão bem fundamentado conceitualmente como é o caso do Projeto Perforum não encontrava apoio oficial na época; enquanto que outros projetos menos originais e pouco produtivos encontraram facilemente acesso a recursos estatais provenientes de renúncia fiscal?

Essas especulações, aliadas aos depoimentos dos participantes do Projeto Perforum como Paula Perissinotto e Beatriz Bianco, que na época se propuseram a captar recursos para o projeto deve esclarecer sobre os procedimentos de apoio cultural não só daquela época, mas também dos dias atuais; pois muitos dos mecanismos burocráticos ainda persistem inalterados até os dias de hoje.

${ }^{23}$ http://www.acessoainformacao.gov.br/sistema/site/index.html - Acesso em 02 de fevereiro de 2013. 


\subsection{DIVISÃO DOS CAPÍTULOS}

O primeiro capítulo, Introdução, apresenta o tema e esclarece sobre a metodologia aplicada à pesquisa, além dos principais conceitos envolvidos. Também discute o uso dos mapas conceituais e o recurso à Lei de Acesso à Informação.

O segundo capítulo, Contexto histórico-cultural: Projeto Perforum no contexto da Pós-Modernidade, faz uma análise do ambiente Internacional e brasileiro da época, com destaque para o advento das novas tecnologias da informação e as discussões sobre a pós-modernidade que ocuparam os intelectuais do período.

O capítulo terceiro, Projeto Perforum contestando os $\mathbf{5 0 0}$ anos do Brasil, analisa as propostas deste projeto e o uso da tecnologia digital e telemática.

O quarto capítulo, Ano 2000: As Comemorações dos 500 anos do Brasil, aborda outras duas propostas de eventos, no contexto das comemorações dos 500 anos da chegada dos portugueses ao Brasil; a "Bienal + 500" e os protestos de Porto Seguro. Inclui-se aqui descrições das propostas, eventos realizados e depoimentos de participantes.

O capítulo quinto, Projeto Perforum - Desterro: Ensaios de telepresença, aborda a continuidade do Projeto Perforum, com transmissões entre São Paulo e Florianópolis, dentro da proposta de um projeto paralelo denominado Perforum Desterro. Para tanto foram exploradas as possibilidades da telepresença.

O sexto capítulo, A Questão da Documentação e Preservação da Arte Telemática, reflete acerca de alguns critérios de documentação, desafios e propostas para a preservação de projetos de telearte, especialmente o Projeto Perforum.

Para finalizar, empreendemos um balanço das atividades desenvolvidas pelo Projeto Perforum e as consequências para a Arte e Tecnologia no Brasil naquele momento. 
2.

CONTEXTO HISTÓRICO-CULTURAL:

PROJETO PERFORUM NO CONTEXTO DA PÓS-MODERNIDADE

Afortunadamente hay signos de que la ciencia se está volviendo más subjetivista y el pesimismo posmoderno puede entonces acompañarla. No hay dudas de que artistas y científicos comparten la curiosidad sobre cómo los avances de la alta tecnología pueden ayudar a la exploración de la mente. Y la alta tecnología, por sí misma, está llamada a cuestionarse nuestras nuestras definiciones de qué es ser humano y qué debe constituir una conciencia artificial en las formas de vida artificial emergentes. $(\text { ASCOTT })^{24}$.

${ }^{24}$ ASCOTT, Roy. Disponível em http://aleph-arts.org/pens/ascott.html. Acesso em 19 de Setembro de 2013. 
O movimento que se denomina "arte e tecnologia" no final do século XX precisa ser contextualizado, pois, apesar das novas mídias, ele não é independente de uma tendência artística que teve início um século antes.

A história da arte moderna que se estendeu dos Impressionistas de Cézanne até Mondrian e Pollock, foi a história da demolição das estruturas de espaço e tempo, de movimento e ordem dos modelos visuais legados pela tradição. (SANTAELLA, 2003, p. 154)

A partir daí, até o surgimento das vanguardas artísticas mais radicais como o suprematismo, cubismo, surrealismo e o dadaísmo, ocorreu um desencadeamento sucessivo de contestação da linguagem e do próprio objeto artístico.

Duchamp começou a colocar no museu partes de objetos encontrados na rua: roda de bicicleta, porta-garrafas, vaso sanitário. A partir disso, o artista se viu liberado para a sua demanda de reinteração da arte com a matéria vertente da vida. Foi seminal a influência de Duchamp em todas as manifestações subsequentes da arte na busca de fusão com a vida, nos happings e nas artes do corpo, quando o próprio corpo do artista foi se transformando em obra de arte. (SANTAELLA, 2003, p. 154)

Portanto, só podemos pensar um evento como Projeto Perforum que com o auxilio da tecnologia busca o tempo presente e desafia as limitações espaciais na sequência de movimentos artísticos que também tinham como foco a própria linguagem.

Desde as primeiras décadas do século $X X$, a fotografia e o cinema experimental já estavam começando a se afirmar como novas formas de arte. Dos anos 50 e 60, o cinema experimental voltou a receber um grande impulso principalmente nas obras de artistas do movimento Fluxus. Rush (1999, p. 25-26) afirma que, em 1966, o acervo desses artistas já atingia o número de 40 filmes breves. Nas artes plásticas, enquanto Mondrian levava a pintura ao limite das meras variações de ângulos retos e cores primárias, Pollock a transformava na pura energia do gesto. Ao mesmo tempo, com a revolução eletrônica, um bom número de novas tecnologias começava a surgir, colocando-se à disposição do imaginário artístico. (SANTAELLA, 2003, p. 155-156).

Quanto ao uso das tecnologias eletrônicas, ao longo do século XX, artistas já tinham se aventurado pelos novos meios: rádio, televisão, até a sofisticação alcançada com a utilização do vídeo, quando esse se tornou viável, se adequando aos usos estéticos: 
Antes de 1965, quando a Sony lançou, com preço razoável o equipamento portátil de vídeo, chamado de Portapak, o tratamento do meio televisivo se dava predominantemente pelo uso do aparelho de TV como um objeto e, portanto, como uma quase-escultura. Uma das razões para isso estava no fato de que os artistas não tinham acesso aos mesmos recursos técnicos sofisticados, disponíveis aos profissionais das companhias de televisão. Outra razão estava na crítica à televisão comercial que os artistas levavam a cabo. (SANTAELLA, 2003, p. 157).

A partir daí, cada vez mais os artistas vão recorrer às tecnologias que vão surgindo em gerações sucessivas de aperfeiçoamento técnico e acessibilidade. Os debates sobre a pertinência do uso dessas tecnologias na arte seguem em paralelo.

Ao mesmo tempo em que, depois das vanguardas artísticas, já não é possível questionar o uso de recursos, seja lá qual for, a contestação se coloca quanto à validade dos meios como conteúdo: será que as novas tecnologias seriam capazes de revolucionara as linguagens artísticas, ou seriam apenas instrumentos a serviço de ideologias tradicionais.

Les débats courants portant sur l'image et La visualité abordent le déplacement dans les arts cause par les nouvelles technologies en termes de rupture et de fracture alors que les similitudes et les continuités, même dans lês exposés historiques, ne sont em comparaison guère examines. Le défi dês Technologies numériques transformation dês processus de production, changements dans Le mode de distribution, elargissement de l'accès aux technologies de prouction - est communément décrit em termes de "nouveau". Le disours numérique promet La nouveauté, décrivant ces changements comme une fracture, identifiant La nouveauté avec la perte de tout point de référence antérieur. Par contraste, lês critiques dês artes assistes par ordinateur ont constamment soutenu que l'usage dês outils numériques resulte somme toute de l'imitation de formes d'art antérieures, de telle sorte que Le "nouveau" des nouveaux médias est obtenu principalement par réinscription, retravail et assimilation d'éléments et de concepts esthétiques originellement développés dans des médias artistiques antérieurs, tout particulièrement La peinture, La photographie et le film. (Yvonne Spielmann - in: COUCHOT, 2001, p. 101 e 102).

De fato o uso das novas tecnologias coloca novas questões.

Os sistemas integrados da telemática oferecerão certamente uma opulência de imagens, atualizando inesgotáveis fontes de informação, através de uma abundância de meios. Contudo, este processo pode simplesmente ocultar um despistamento ideológico. A abundância informativa pode ser um instrumento de se ocultar informações sensíveis e primordiais. (MATUCK, 1996, p. 269). 
Há mesmo aqueles que consideram a introdução de novos meios como um empobrecimento do potencial artístico de comunicação.

Os críticos da telemática denunciam que a multiplicação dos sistemas resultaria mesmo no empobrecimento da comunicação entre indivíduos e grupos: "é necessário assinalar que este excesso de comunicação - a opulência comunicativa - parece implicar a descomunicação social” ${ }^{25}$. (MATUCK, 1996, p. 269).

Matuck responde a essa questão:

O que se depreende é que o potencial redentor da tecnologia se esvai, se uma ação política conjugada não for exercida determinantemente por aqueles que se tornarão usuários. A possibilidade dos receptores atuarem como emissores pesará enormemente neste processo de conscientização política e mediática, mas não será o único fator na otimização destes sistemas. (MATUCK, 1996, p. 272).

Ascott, assim, sintetiza o advento das novas tecnologias no âmbito das linguagens artísticas:

The past decade has seen the two powerful technologies of computing and telecommunications converge into one field of operations, which has drawn into its embrace other electronic media, including video, sound synthesis, remote sensing, and a variety of cybernetic systems. These phenomena are exerting enormous influence upon society and on individual behavior; they seem increasingly to be calling into question the very nature of what it is to be human, to be creative, to think, and to perceive, and indeed our relationship to one another and to the planet as a whole. The "telematic culture" that accompanies the new developments consists of a set of behaviours, ideas, values, and objectives that are significantly unlike those that have shaped society since the Enlightenment. (ASCOTT, 2003, p. 232).

${ }^{25}$ FONTCUBERTA, Mar de \& MOMPART, Joseph, L. Gomes, Alternativas de Comunicacíon, p.130 IN: MATUCK, 1996. 


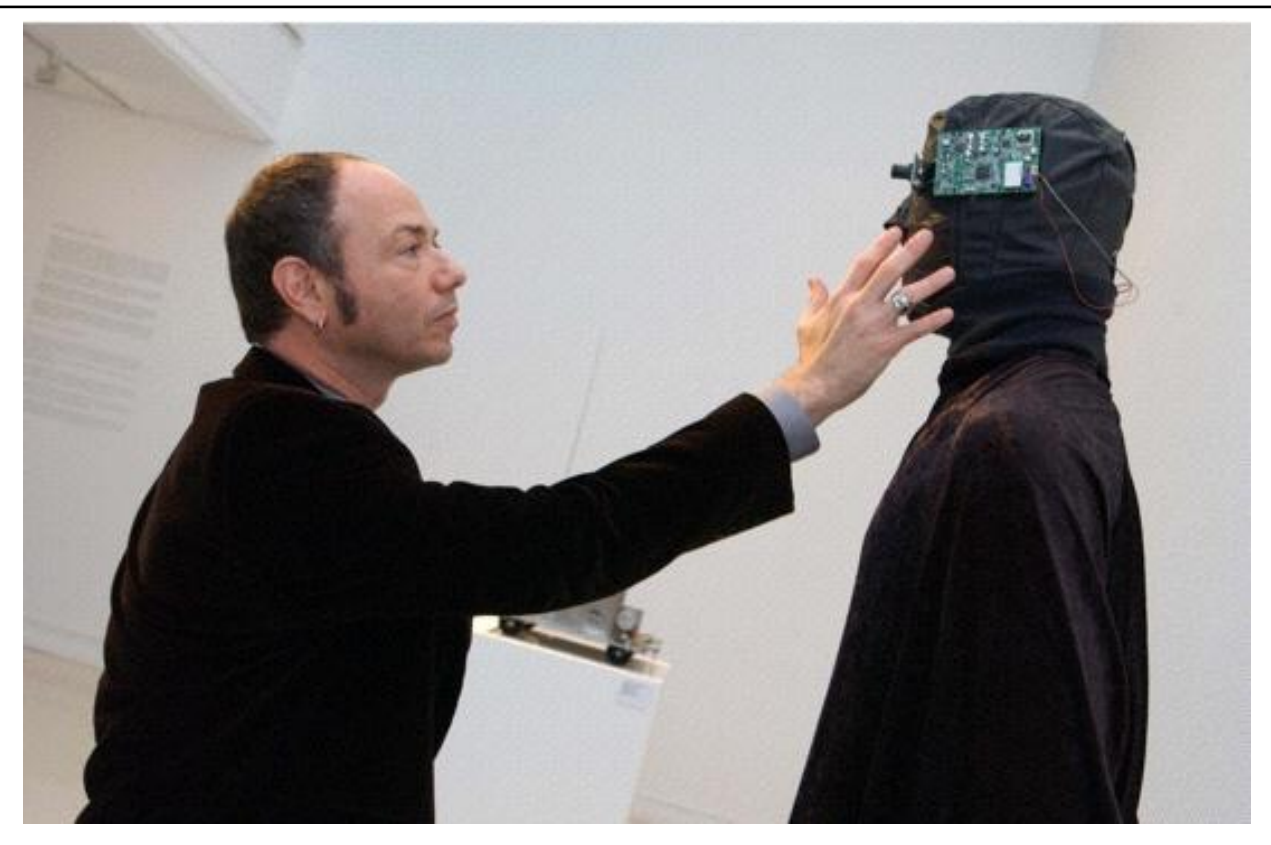

Figura 2: O artista e pesquisador brasileiro Eduardo Kac, radicado nos EUA, foi um dos primeiros seres humanos que implantou um microchip em seu corpo. Ele fez isso em seu trabalho "Time Capsule" (1997), como uma crítica social, considerando a relação entre pessoas e a tecnologia.

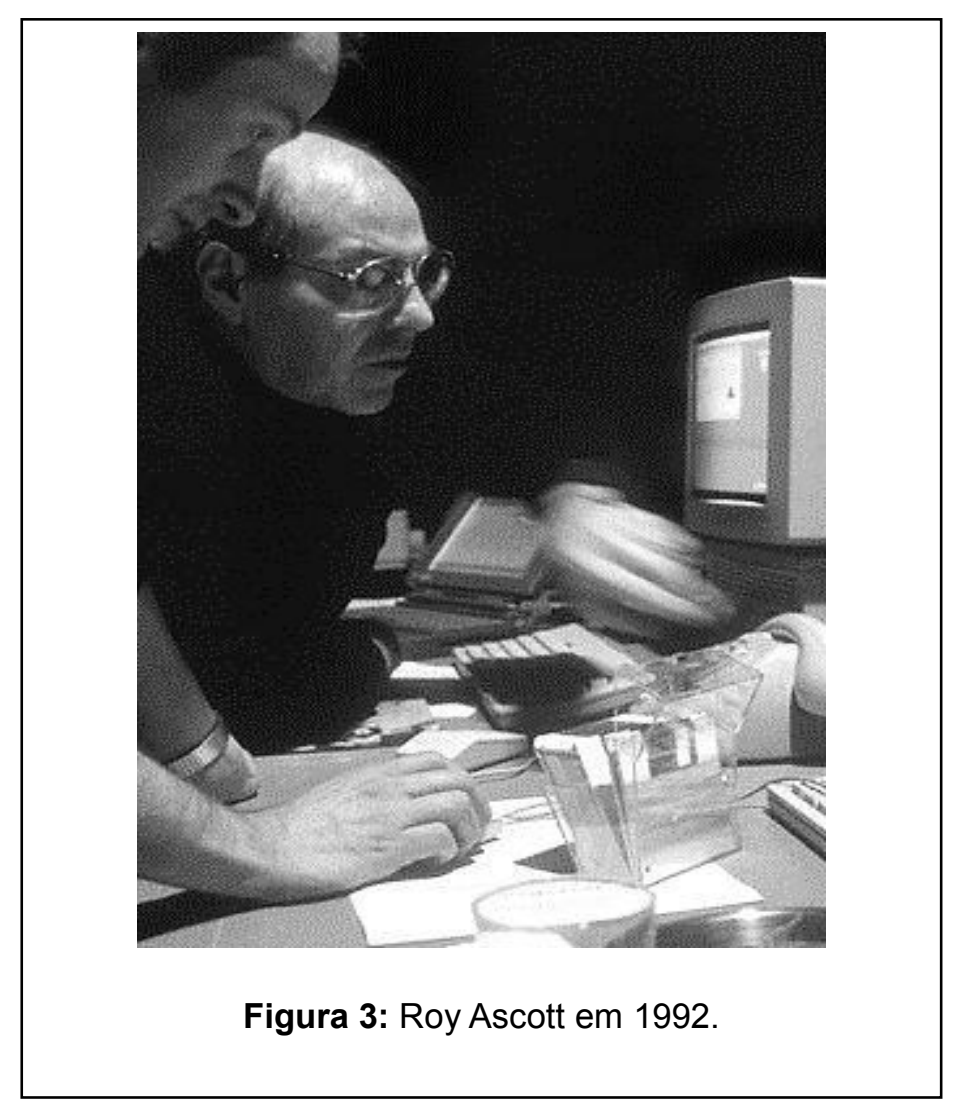


Evidentemente caberá a cada artista, individualmente, estabelecer o grau de utilização das novas técnicas. Na realidade, a questão técnica sempre existiu no fazer artístico. O que está em jogo no emprego das tecnologias eletrônicas é a intensidade de utilização dos recursos, uma vez que as possibilidades são múltiplas.

\begin{abstract}
Maybe for certain kinds of interactions, "less is more". For example, the telephone highlights a set of audio codes but as the loss of all others. This might serve the user better by buffering certain kinds of interaction like home shopping, registering a complaint, or lurking in some virtual environment. In certain interaction it is likely that users might find it helpful to restrict visual information. This might have cognitive benefits as when the audio channel carries most of the critical information (e.g., speeches or verbal instructions). (BIOCCA, 1995, p. 148).
\end{abstract}

Porém, o uso das tecnologias eletrônicas começa a se tornar produtiva quando é capaz de aumentar o potencial comunicativo da arte.

In virtual environments, the use of artifacts to augment interpersonal communication codes may be greatly enhanced. Artists often invent or explore these codes. McLuhan argued that "The artist is the person who invents the means to bridge between biological inheritance and the environments created by technological innovation" (McLuhan \& McLuhan, 1988, p. 98). This may be true of the development of augmented interpersonal communication codes. (BIOCCA, 1995, p. 153 e 154).

Por outro lado, não dá para dizer que nada mudou com a difusão das novas tecnologias nos anos 90 .

De fato, a reconfiguração do corpo humano na sua fusão tecnológica e extensão biomaquínicas está criando a natureza híbrida de um organismo protético, ciber, que está instaurando uma nova relação ou continuidade eletromagnética entre o ser humano e o espaço por meio de máquinas. Esta paradigmática reversão de perspectiva em nosso horizonte tornou essencial a superação da oposição entre o universo orgânico do corpo e o universo mecânico da tecnologia em prol de uma nova lógica da complexidade capaz de reconhecer que a vida do corpo e seus ambientes extremos e mesmo internos estão inextricavelmente mediados pelas máquinas ${ }^{26}$.

Nesse contexto, o momento é propício para o surgimento de formas variadas de arte:

A variedade das artes existentes e que continuam nascendo nesses ambientes híbridos e complexos é inumerável. São formas e processos muitas vezes tão enigmáticos quanto é enigmático o

${ }^{26}$ PALUMBO, 2000, p.31. IN: SANTAELLA, 2004 - Corpo e Comunicação, p. 75. 
destino para o qual as transmutações apontam. Uma constante em todas essas formas biocibernéticas de arte encontra-se no fato de que, por estarem lidando com o cerne das tecnologias interativas, essas artes trazem o corpo do receptor para dentro, não apenas do processo de transmissão da obra, como é o caso das várias formas de instalação, mas do próprio processo de realização da obra. (SANTAELLA, 2004 - Corpo e Comunicação, p. 77).

Em certos casos as novas tecnologias servem para instrumentalizar tendências artísticas que já se prenunciavam nos anos 1960.

Muitas das artes participativas do século $X X$, de que as obras de Lygia Clark e Hélio Oiticica no Brasil são exemplares, obras que apelavam para a entrada do receptor na obra, sem o que ela não acontecia, já anteciparam o que viria a se tornar o princípio definidor das artes do corpo biocibernético. (SANTAELLA, 2004 - Corpo e Comunicação, p. 77).

Sem dúvidas as novas tecnologias computacionais facilitam a participação do público na obra de arte, caracterizando-se como "interatividade".

Nesse novo contexto, o emissor não emite mais mensagens, mas constrói um sistema como rotas de navegação e conexões. A mensagem passa a ser um programa interativo que se define pela maneira como é consultado, de modo que a mensagem se modifique na medida em que atende às solicitações daquele que manipula o programa. Essas manipulações se processam por meio de uma tela interativa ou interface que é lugar e meio para o diálogo. (SANTAELLA, Navegar no Ciberespaço, 2004, p.163). 


\section{ROY ASCOTT}

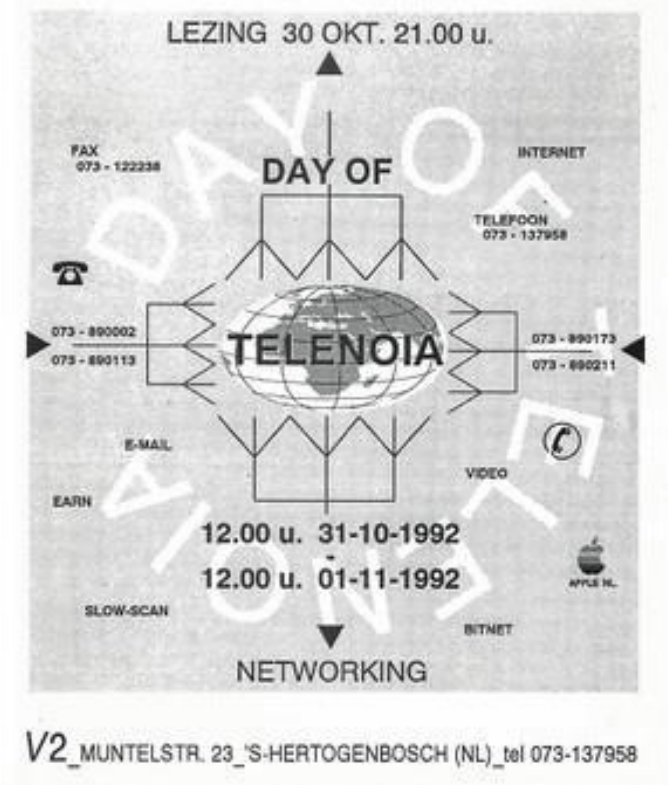

Figura 4: Roy Ascott - Telenoia (folheto).

Num universo de simulação a própria interatividade é simulada.

Por intermédio de instrumentos materiais (tela, mouse, teclado) e imateriais (linguagem de comando), o receptor transforma-se em usuário e organiza sua navegação como quiser em um campo de possibilidades, cujas proporções são suficiente grandes para dar a impressão de infinitude. Os programas interativos ainda oferecem ao navegador a possibilidade de mudar de identidade e de papel numa multiplicidade de pontos de vista. Os programas são formas de elaborar pensamentos e levam o usuário a incorporar identidades geradas no ciberespaço. (SANTAELLA, Navegar no Ciberespaço, 2004, p.163).

Inserido nesse universo comunicacional, o Projeto Perforum buscava explorar artisticamente as possibilidades das novas mídias, mas num sentido dialógico, sem se deixar enfeitiça pelas simulações de interatividade.

Nas diversas formas que a interatividade no ciberespaço propicia, ao contrário, são os fluxos de signos, os jogos de linguagem, aquilo que, no jargão comum, é chamado de fluxos informacionais, que ocupam o primeiro plano. Quando as subjetividades se engajam nesses jogos, fica explícito que é apenas ilusório o controle privado da 
linguagem encenado na comunicação face-a-face. A interatividade no ciberespaço põe a nu o verdadeiro caráter dialógico da linguagem que não se confunde, como se pensa, com dois egos que se defrontam para negociar significados negociados em suas mentes. Tanto para Bakhtin quanto para Peirce, a fala não é propriedade privada de um eu habitado pela linguagem. Linguagem é fluxo constante tal como as redes comunicacionais do ciberespaço potencializam. (SANTAELLA, Navegar no Ciberespaço, 2004, p.171).

\section{Vejamos a nossa situação comunicacional na época do Perforum:}

Communication in the age of virtual reality is in some ways about transportation. Tele-presence replaces te-vision. The body's sensorimotor channels are conveyed to distant real and virtual worlds. Experience is transmitted. Transmission and transportation share more than a common root word. In the $19^{\text {th }}$ century, telegraph wires and train tracks raced side-by-side across a fields and forests of America's western frontier. These two transmission channels, the train and the telegraph, competed to "transport" information. Trains, planes, and trucks still transport information carried on physical media like paper and ink: mail, newspaper, and magazines - consider, for example, the postal system. Although the telegraph had far less information-carrying capacity than the train, it easily outraced the physical transportation channel. The telegraph's thin flow of information was more valuable than the train's car loads of slow information. The flow communication is now sent across space and time through various transmission channels: copper wires, fiber optic cables, the electromagnetic spectrum, and so forth. Millions of miles of wires criss-cross the planet and wrap it like a giant ball of spring. Surrounding this giant ball, the electromagnetic spectrum thrums with the chant of millions of messages. The transmission of information surrounds us. (BIOCCA, 1995, p. 20).

Não que a transmissão de sons e imagens fosse um fenômeno recente. Na verdade, a evolução das telecomunicações teve início ainda no século XIX com os cabos telegráficos - e a partir daí foi ganhando terreno incessantemente. No entanto a novidade é a acessibilidade dos meios. Até então a comunicação (de massa) estava nas mãos dos governos e das grandes empresas, a partir do computador pessoal (PC) - a tecnologia torna-se acessível aos indivíduos. Os artistas mais sensíveis às mudanças tecnológicas e as possibilidades das novas mídias que poderiam ser utilizadas esteticamente.

Again we hear echoes from the early days of modern communication. The shouts that "space will be annihilated" were first clearly audible with the arrival the telegraph (Carey, 1988; Czitrom, 1982). The gentle tapping of the finger on a telegraph key collapsed miles. Now the rest of the body is being attached to the descendants of the telegraph wire. In telepresence, virtual reality joins other media in the 
task of transporting experience. (BIOCCA, 1995, p. 23).

Ora a tecnologia toca aspectos muito caros à arte - como a percepção do espaço, reprodução da imagem (à distância) e transporte de experiência corporal.

Com a presença do computador, de interfaces de acesso e da síntese numérica, as tecnologias oferecem percepções de mundos em que as relações se desenvolvem em boa parte no espaço imaterial de databases por dados estocados em computadores pessoais isolados, ou conectados em redes. Na cibercultura, o homem experimenta a interatividade com máquinas e seus bancos de dados, a comunicação planetária com os sistemas telemáticos, a imersão em ambientes virtuais, em uma identidade não linear, hiperconectada e distribuída em escalas globais, em mesclas do real e do virtual tecnológico (DOMINGUES, 2002, p. 31).

Para o artista Artur Matuck que já vinha há bastante tempo buscando a interatividade à distância, o uso do slow scan e do telefone, foi muito bem vindo. "Numa dimensão planetária, as redes telemáticas somam recursos informatizados com as tecnologias de comunicação como telefones, fax, modem e satélites, e ampliam em escalas planetárias o ambiente para o corpo". (DOMINGUES, 2002, p. 32). Nesse contexto é inevitável que surja uma nova estética, que no ambiente permissivo da pós-modernidade se espalha facilmente.

Podemos contextualizar as formas de sentir do visual tecnológico como integrantes de uma nova estética, as ciberestética, na qual o corpo age, pensa e sente acoplado a corpos sintéticos de computadores cujos dispositivos de acesso nos permitem entrar nas informações. (DOMINGUES, 2002, p. 32).

Tanto que a percepção da época era de que se estava vivendo o momento de ruptura e redefinição da experiência humana.

Como em outros momentos da história, as tecnologias redefinem a experiência humana. Veja-se o que ocorreu na relação entre indivíduos com base na imprensa, com a reprodução fotomecânica, a fotografia, a telegrafia, o telefone, o fonógrafo, a eletrocópia, o cinema, o rádio, a televisão, o vídeo e agora o computador pessoal e a Internet. (DOMINGUES, 2002, p. 32).

Em termos de linguagem artística, há muito tempo os artistas estavam esperando por esse momento. O outro grande momento havia sido o uso do vídeo (vídeo arte). Agora com o computador e a televisão, outro grande salto qualitativo seria possível. 
As tecnologias interativas têm o poder de modificar o cenário social pela introdução de novas formas de comunicação e negociação de significados. É pela introdução em larga escala de tecnologias informatizadas na era digital que se verificam, portanto, alterações as esferas da cibercultura. (DOMINGUES, 2002, p. 32).

Quanto ao alcance das mudanças estéticas, naturalmente temos que descontar o entusiasmo da época, sob o impacto da introdução das novas tecnologias. No entanto, de fato, tivemos consequências importantes para a linguagem artística, envolvendo novos temas e abordagens.

Nas últimas décadas, as tecnologias interativas estão provocando os artistas a reinventarem o processo de criação e de fruição da arte em hibridização que mesclam o natural e o artificial tecnológico. Usam as invenções tecnológicas para gerar ambientes novos para o sentir e provocam mutações nas relações do espectador com a obra que deve ser entendida como um sistema. Com o advento do computador, os artistas pensam a criação com softwares, interfaces, a rede Internet, a hipermídia, os ambientes em realidade virtual, a robótica, a vida artificial, os sistemas de multiagentes, entre outras situações de extrema complexidade geradas em ambientes que utilizam o ciberespaço e que antes de mais nada provocam comportamentos humanos estendidos pelas tecnologias. Buscam gerar campos sensíveis de relação entre o homem e as tecnologias. Assim, as tecnologias interativas estão colocando a arte num cenário mais vasto de reflexão em discussões que entrelaçam campos como a engenharia, a neurociência, os sistemas artificiais com relações interdisciplinares da área de Artes, Comunicação, Ciência da Computação, Ciências Cognitivas, Ciências Sociais, Ciências Biológicas e com a demanda de práticas de laboratórios que pedem o trânsito de conhecimentos entre as várias áreas. As formas de criação e as produções levam em conta a maneira como as inovações tecnológicas estão serviço da criação, considerando-se o sistema proposto, tipo os de interfaces, o design, a originalidade da criação e a visão particular de artistas e cientistas de incorporar essas tecnologias no circuito da arte. (DOMINGUES, 2002, p. 225).

Para Domingues, os impactos na produção e conceituação da arte são evidentes:

As tecnologias interativas modificam substancialmente as circunstâncias de produção e o conceito de objeto artístico. Como consequência, o artista troca sua "torre de marfim", seus ateliês e oficinas, seus vínculos com o mercado de arte como objeto, a autoria e o "eu" modernista, por investigações criativas em laboratórios ligados à informática, produz em oficinas e laboratórios de mecânica, da eletrônica próprios dos sistemas de automação industrial, frequenta centros de produção de imagens científicas das ciências médicas, da biologia, da genética, do sensoriamento remoto, da 
astrofísica. (DOMINGUES, 2002, p. 225 e 226).

A seguir, ASCOTT (2003), num outro tema muito valorizado por Artur Matuck, que é a autoria e a colaboração na produção artística.

Telematics is the system of systems in which these principles can most clearly be manifested. Telematic networks can carry images and texts in new forms of conjunction, mediated by computer process in a flux of meanings in which there are no "senders" and "receivers" (as in the old models of information theory) but only "users," whose intervention will be more or less creative depending on the degree of their participation in the system. In telematic networks, the screen of transformations replaces the mirror of reflections, providing the branching, interacting pathways through which telematic process can discharge its creatibve collisions and conjunctions of inputs and, as for particles in a cloud chamber, provide a planetary field for the dance of data - much as Nietzsche saw thinking itself: a dance of concepts and the pen. (ASCOTT, 2003, p. 207).

Daí para se chegar a uma autoria dispersa depende somente do desprendimento dos artistas mediáticos.

Telematic process, coupling together by satellite, cable, and threads of optical fibre a vast diversity of world-wide inputs, celebrates the death of the "individual", "original" author of images or texts. It brings into being, instead, a new "dispersed authorship" generating massive variety within the virtual "immateriality" of the networks. (ASCOTT, 2003, p. 207 e 208).

O interessante é que essa tendência não é uma simples consequência das possibilidades das novas mídias, mas se apoia numa evolução da arte contemporânea - com críticas tão brilhantes como Barthes, citado por Ascott:

In the space of the computer memory, this endless activity of inputs, retrievals, and regroupings of creative data constitutes an image/ intertext. Telematics brings a new order of discourse into being that embodies and amplifies Barthes's earlier insight: "We now know that the text is not a line of words releasing a single 'theological' meaning (the 'message' of an 'Author-God') but a multidimensional space in which a variety of writings, none of them original, blend and clash. The text is a tissue of quotations drawn from innumerable centres of culture" [Barthes $1975^{27}$ ]. (ASCOTT, 203, p. 208).

Foi nesse espírito que o Projeto Perforum se propôs à telemática, pois:

${ }^{27}$ BARTHES, Roland. The Pleasure of the Text. New York: Hill \& Wang, 1975. 
The dance of data and free play of sense are atributes that telematic process can only amplify. The "blend and clash" of images and text from innumerable inputs, in innumerable locations, reflecting innumerable cultures and contexts, has the potencial to bring about na epiphany of creative mind. (ASCOTT, 2003, p. 209).

É um novo paradigma de arte que surge, não com os novos meios - porque a tendência já estava dada em contrapartida ao esgotamento do modernismo (vanguardas). Como aponta Ascott:

I would like to look at the attributes of a paradigm for art, a field theory that would replace the formalist modernist aesthetic. It takes as its focus not form but behaviour; not an information model of the sending/receiving of messages in a one-way linearity but the interrogation of probabilities by the viewer; it looks at a system in which the artwork is a matrix between two sets of behaviours (the artist and the observer), providing for a field of psychic interplay that can be generative of multiple meanings, where the final responsibility for meaning lies with the viewer.(ASCOOT, 2003, p.178).

Dessa maneira, o emprego das novas tecnologias telemáticas na arte nos ajuda a ter uma melhor percepção do significado da pós-modernidade, em oposição à modernidade.

The insistent linearity in time of formalist modernism was tied to the idea of progress and the future; the styles and the modes of the modernist aesthetic were linked almost causally in a straight line, on which there was no going back, for it was thought that to look to the past could only be regressive. I wish to point instead to a cyclical universe of interactions in space, time, and consciousness, where past, present, and future mingle, where the objective and subjective find their operational link in probability and indeterminacy, where we can explore the matrix of matter and psychism. Ambiguity, associative linkages, the boundary regions of art and consciousness, crossing the lines between individual dreams, memories and events, between cultures and histories: this is the prospectus for postmodernism. (ASCOTT, 2003, p. 179).

Artur Matuck já vinha sendo reconhecido como um artista de telecomunicações e arte, pelo menos desde o Projeto Refluxo. Segundo Matuck:

quando eu morava em Pittsburgh e eu trabalhava junto com a Maria Aparecida da Silva, e a gente fez o Projeto Refluxo praticamente juntos, eu e ela, na Carnegie Mellon University, e o Projeto Refluxo teve muita repercussão, assim, envolveu 100 artistas do mundo 
inteiro. (Matuck - entrevista).

Esses eram tempos heroicos, antes da difusão da internet, quando a tecnologia mais utilizada pelos tele-artistas era o fax. Foi nesse contexto, ao final da década de 1990, que surgiu a primeiro conceito sobre o Projeto Perforum. Com baixa tecnologia, mas já com elevado grau de interatividade e autoria múltipla.

E a minha ideia do Projeto Perforum dessa época, como ele foi concebido era fazer um tipo de um púlpito virtual em Veneza, em que pessoas que quisessem se manifestar, falar politicamente especialmente, elas mandariam suas mensagens ou falariam a distancia e essas mensagens seriam veiculadas na Bienal de Veneza, vindas de vários países, de várias localidades, de várias pessoas. (Matuck - entrevista).

Durante as décadas de 1980 a 2001, Artur Matuck coordenou eventos de arte-comunicação em que eram utilizados vídeo, slow scan television, telefone, fax e microcomputador. Através desses dispositivos de telecomunicações, promoveu um intercâmbio não só entre artistas e pesquisadores da área, mas envolveu pessoas de diferentes países e culturas; entre esses eventos, o Projeto Reflux:

O projeto se auto-define como "um evento de telecomunicação e arte" propiciando um "ambiente de aprendizado para intercâmbio descentralizado". Reflux foi concebido a partir da ideia de que eventos de telearte poderiam ser projetados em termos de fluxos informacionais. Reflux pretendeu construir uma estrutura para possibilitar que diferentes grupos criativos através do mundo gerassem trabalhos de arte dialógica. (MATUCK, 2006, p. 60).

Esse projeto foi um momento decisivo na abordagem das relações entre as telecomunicações e a arte.

Quase todos os projetos anteriores de telecomunicações e arte eram estruturadas a partir de um núcleo gerador que propunha um tema a ser discutido e referendado pelos outros participantes.

O projeto Refluxo, ao contrário, propôs que indivíduos e grupos participantes, em cada terminal, tivessem autonomia para criar suas próprias propostas de arte dialógica e enviá-las para a rede formada pela totalidade dos grupos e espalhada pelo planeta. Cada terminal teria portanto um papel ativo e significativo, tanto como fonte quanto como receptor de informação estética. (MATUCK, 2006,61). 
Vejamos a seguir uma tabela com algumas das principais realizações relacionadas ao Perforum:

\begin{tabular}{|c|c|}
\hline $\begin{array}{l}\text { Trabalhos e } \\
\text { participações de } \\
\text { Artur Matuck }\end{array}$ & Breve relato \\
\hline $\begin{array}{l}\text { Sky Art Conference } \\
\text { São Paulo/Cambridge } \\
\text { (1986) - participação. }\end{array}$ & $\begin{array}{l}\text { Teleperformance transmitida via slow scan television (sstv) } \\
\text { entre o Museu de Arte Contemporânea da Universidade de } \\
\text { São Paulo e o MIT Sky Art conference em Cambridge, } \\
\text { Massachusetts, USA. Utilizaram-se aparelhos de varredura } \\
\text { lenta (sstv) e linhas telefônicas. O equipamento permitia } \\
\text { que imagens de televisão fossem transmitidas via telefone } \\
\text { de uma a outra, ainda que lentamente, e através de } \\
\text { imagens estáticas que se sucediam num intervalo de } 12 \\
\text { segundos. Matuck apresentou uma obra de ficção científica } \\
\text { chamada Specimortigo (destruição da espécie, em } \\
\text { Esperanto). }\end{array}$ \\
\hline $\begin{array}{l}\text { Intercitties São } \\
\text { Paulo/Pittsburgh } \\
\text { (1988) - em } \\
\text { colaboração. }\end{array}$ & $\begin{array}{l}\text { Evento de telecomunição entre a Carnigie-Mellon } \\
\text { University e o Museu de Imagem e Som de São Paulo, } \\
\text { contava com a transmissão de imagens e sons via slow } \\
\text { scan television, sob a organização e participação de Artur } \\
\text { Matuck e Paulo Laurentiz, em São Paulo, e Bruce Breland, } \\
\text { em Pittsburgh. }\end{array}$ \\
\hline Telesthesia (1991) & $\begin{array}{l}\text { Coordenado por Artur Matuck na Universidade de São } \\
\text { Paulo, o projeto Telesthesia consistiu na transmissão de } \\
\text { mensagens em correio eletrônico para o núcleo do The } \\
\text { Studio for Creative Inquiry, localizado em Pittsburgh, EUA. } \\
\text { Este projeto foi tema do Art.com, evento em rede de } \\
\text { computadores focado em comunicação e arte } \\
\text { contemporânea. }\end{array}$ \\
\hline Reflux (1991-1992) & $\begin{array}{l}\text { Considerado pioneiro da produção estética colaborativa em } \\
\text { redes, este projeto permitiu a utilização de tecnologias de } \\
\text { telecomunicações na arte e linguagem investigativa, } \\
\text { proporcionando discussões estéticas entre os participantes. }\end{array}$ \\
\hline $\begin{array}{l}\text { Proto Arte Telemática } \\
\text { (1992) }\end{array}$ & $\begin{array}{l}\text { Uma série de intercâmbios telemáticos via telefone, fax e } \\
\text { videofone ligaram o novo museu (Museu de Arte } \\
\text { Contemporânea da USP) à instituições culturais do interior } \\
\text { de São Paulo, europeias e norte-americanas. }\end{array}$ \\
\hline Landscript (1995) & $\begin{array}{l}\text { O projeto iniciava com uma máquina de escrever virtual e, } \\
\text { a medida que o visitante escrevia, suas palavras eram } \\
\text { alteradas pelo computador, reconstruindo-as num processo } \\
\text { de desescritura. O espectador e suas ações se fundiam à } \\
\text { poética do artista. }\end{array}$ \\
\hline Perforum (1999-2001) & $\begin{array}{l}\text { O projeto "Perforum" lidou com a transmissão de } \\
\text { performances interativas através da estrutura de } \\
\text { videoconferência. Ao longo de dois anos, formou um banco } \\
\text { de roteiros de performances participativas. }\end{array}$ \\
\hline
\end{tabular}




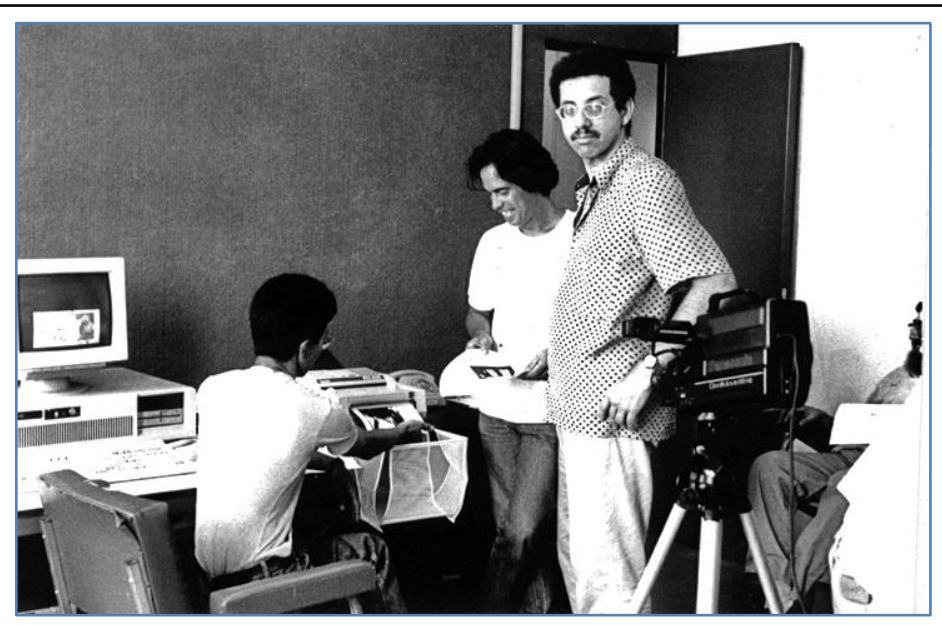

Figura 5: Projeto City Portraits concebido e dirigido por Karen O'Rourke, com imagens realizadas desde 1989 pelo grupo Art-Réseaux de Paris (Christophe Le François, Isabelle Millet, Delphine Notteau, Karen O'Rourke, Gilbertto Prado, Hélène Spychiger, Michel Suret-Canale, entre outros) e seus correspondentes de nove cidades europeias e americanas (no Brasil, Paulo Laurentiz, Artur Matuck, Milton Sogabe, entre outros; em Chicago, Carlos Fadon Vicente, Irene Faiguenboim e Eduardo Kac).

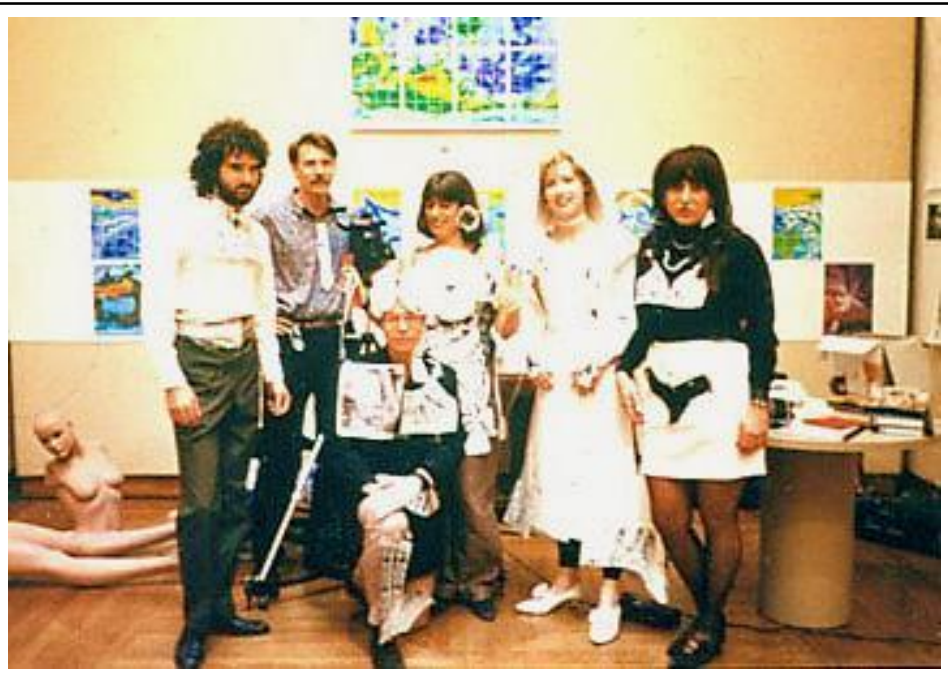

Figura 6: Participantes do Projeto Reflux na Carnigie Mellon University, em Pittsburg (1991-1992). 
3.

PROJETO PERFORUM

CONTESTANDO OS 500 ANOS DO BRASIL

Os brancos são engenhosos, têm muitas máquinas e mercadorias, mas não têm nenhuma sabedoria. Não pensam mais no que eram seus ancestrais quando foram criados. Nos primeiros tempos, eles eram como nós, mas esqueceram todas as duas antigas palavras. Mais tarde, atravessaram as águas e vieram em nossa direção. Depois, repetem que descobriram esta terra. Só compreendi isso quando comecei a compreender sua língua (Davi Kopenawa) ${ }^{28}$.

${ }^{28}$ YANOMAMI KOPENAWA, Davi, Descobrindo os brancos. In: NOVAES, Adauto, A outra margem do Ocidente. São Paulo: Minc-FUNARTE/Companhia das Letras, 1999, p. 18. 


\title{
3.1. ENGENHO E ARTE
}

Entre os objetivos do Projeto Perforum, inclui-se refletir acerca do movimento das Navegações do Século XVI, de maneira crítica e inovadora, enfatizando a criação artística colaborativa, através do ciberespaço. Motivado pela comemoração dos 500 anos do Brasil - o Projeto Perforum, em sua primeira fase, remete ao Império Português, que se expandiu a partir do século XVI. Nesse contexto, as travessias oceânicas também são rememoradas.

\author{
E também as memórias gloriosas \\ Daqueles Reis que foram dilatando \\ A Fé, o Império, e as terras viciosas \\ De África e de Ásia andaram devastando, \\ E aqueles que por obras valerosas \\ Se vão da lei da Morte libertando \\ Cantando espalharei por toda a parte \\ Se a tanto me ajudar o engenho e arte. \\ (Luís de Camões, Os Lusíadas, Canto I, 1-2).
}

No entanto, a proposta do Projeto Perforum não se deixava contaminar pelo tom eufórico que geralmente caracterizam comemorações oficiais como essa. Como afirmou LEEUWENBERG (1999): "no século 16, os povos europeus avançaram oceanos afora em busca de novas fontes de produtos para seus mercados. É interessante considerar que a era das grandes navegações, lideradas por portugueses e espanhóis, foi motivada por algo tão prosaico nos dias de hoje como baunilha, cravo e canela" (LEEUWENBERG, 1999, p. 8). Assim, é sempre necessário manter certo distanciamento crítico quando se lida com as comemorações históricas. Mesmo porque a percepção da parte dos indígenas em relação ao encontro com os brancos é bem outra do que a imaginada pelos europeus - como se observa nas declarações do índio Yanomami Davi Kopenawa:

Mais tarde, realmente comecei a crescer e a pensar direito, mas continuei a me perguntar: 'o que os brancos vêm fazer aqui? Por que abrem caminhos em nossa floresta?' Os homens mais velhos me respondiam: 'Eles vêm sem dúvida para visitar a nossa terra para habitar aqui conosco mais tarde!'. Mas eles não compreendiam nada da língua dos brancos; foi por isso que os deixaram penetrar em suas terras dessa maneira amistosa. Se tivessem compreendido suas palavras, acho que os teriam expulsado. Aqueles brancos os enganaram com seus presentes. Deram-lhes machados, facões, facas, tecidos. Disseram-Ihes, para adormecer sua desconfiança: 
'Nós, os brancos, nunca os deixaremos desprovidos, lhes daremos muito de nossas mercadorias e vocês se tornarão nossos amigos!'. Mas, pouco depois, nossos parentes morreram quase todos em uma epidemia, depois em uma outra. Mais tarde, muitos outros Yanomami novamente morreram quando a estrada entrou na floresta e bem mais ainda quando os garimpeiros chegaram ali com sua família (YANOMAMI KOPENAWA, 1999, p. 17) ${ }^{29}$.

Por outro lado, de fato, é possível estabelecer uma relação de analogia entre o "engenho e arte" do tempo das Navegações e a "arte e tecnologia" do final do século XX. Afinal, o império marítimo português também se articulava numa rede de abrangência planetária, utilizando-se das tecnologias mais avançadas da época.

O império marítimo português integrava pontos dispersos nas quatro partes do mundo. Eram fortalezas e pequenas terras delimitadas por oceanos. Contando com população diminuta, a Coroa deveria arquitetar meios de manter vastas áreas sob controle, valendo-se de estratégias para compensar as longas distâncias entre Lisboa e as possessões apartadas. A descontinuidade geográfica era particular no Estado da Índia, que compreendia conquistas e descobertas no imenso litoral ente Moçambique e Macau. Essas possessões formavam redes, unidades interligadas pela circulação de bens, pessoas e instituições. (RAMINELLI, 2008, p. 17).

O domínio espacial era menos relevante, quando comparado à circulação mercantil e ao controle marítimo. Nas localidades, por vezes, a organização jurídica, política e administrativa adaptava-se tanto aos interesses de mercadores portugueses quanto à tradição das comunidades conquistadas ou aliadas ${ }^{30}$.

Embora as possessões se mantivessem interligadas à metrópole, não existia, até o século XIX, uma constituição colonial unificada. $O$ império ultramarino, enfim, significava conexão de pontos dispersos, laços que multiplicaram, entrelaçaram ou extinguiram-se ao longo do tempo. (RAMINELLI, 2008, p. 17).

No tempo das Navegações, a escrita era o veículo mais importante de comunicação que permitia conhecer e administrar um grande império a distância.

Para manter o monarca informado, os vassalos percorriam a costa e as terras, realizavam descobertas e, logo, comunicavam ao centro os resultados do empreendimento. Os primeiros escritos narravam a surpreendente fertilidade do solo, indicavam a existência de minas,

\footnotetext{
${ }^{29}$ YANOMAMI KOPENAWA, Davi. Descobrindo os brancos. In: NOVAES, Adauto, A outra margem do Ocidente. São Paulo: Minc-FUNARTE/Companhia das Letras, 1999, p. 15-21.

30 THOMÁS, Luís Filipe. De Ceuta a Timor. Lisboa: Difel, 1994. (p. 207-210).
} 
mapeavam os rios navegáveis, descreviam os habitantes, as plantas e os animais. Essas notícias eram, aqui e ali, formas de manter as redes em funcionamento, de incrementar os laços entre Lisboa ou Madri e a América. As viagens, enfim, promoviam estreitamento entre mundos apartados. Nos diários, os vassalos recriavam a natureza e os feitos portugueses no ultramar e os conduziam a Portugal ou a Castela, no tempo da união das Coroas. Eram por meio de papéis que o monarca tomava conhecimento das terras, traçava estratégias para posse e efetiva exploração. Os escritos também denunciavam os desmandos dos poderes locais, os contrabandos e as práticas contrárias aos interesses da Real Fazenda. (RAMINELLI, 2008, p. 20).

Naquele tempo das travessias oceânicas "A existência de uma teia de informações era capaz de tornar móvel o mundo colonial, reduzi-lo a questões básicas, traduzi-lo em relatórios, tratados e mapas, e conduzi-lo enfim em forma de papel para os centros europeus. Essas operações eram vitais para a sobrevivência doa ordem colonial, para consolidação de laços entre centro e periferias" (RAMINELLI, 2008, p. 41). Essa tendência persistiu durante o período colonial, sendo mesmo reforçada na época da união das duas Coroas ibéricas. "O fortalecimento da comunicação entre mundos apartados tornou-se uma importante característica do governo filipino, por isso, com toda propriedade o historiador J.H.Elliott ${ }^{31}$ denominou a Monarquia Hispânica de government by paper" (Idem, p. 42). O Projeto Perforum, por sua vez, propunha o uso da telemática como forma de comunicação num mundo globalizado que se distingue pelo "descobrimento do ciberespaço".

Perforum propõe que a reflexão construtiva e estética acerca do entrechoque cultural da Conquista se manifeste, na atualidade, também no descobrimento do ciberespaço. A celebração do processo histórico das Navegações se dará portanto, no presente, através da interação cultural, marcada pela telecomunicação, pela telepresença, pela arte interativa, pelos processos de autoria coletiva. (Projeto Perforum).

\subsection{DIÁLOGO DE CIVILIZAÇÕES}

Fiel à temática do "diálogo de civilizações", uma das primeira atividades do

31 A expressão government by paper se encontra em J.H. Elliott. Imperial Spain; 1469-1716. London: Pengoin Books, 1990. P. 170. 
Projeto Perforum foi a interação com os índios xavante da área indígena de Sangradouro (MT): Hiparidi Top'Tiro e João Lucas Owau, que estavam morando em São Paulo naquela ocasião e se mostravam dispostos a trocar experiências com os brancos.

\begin{abstract}
Eu fui numa palestra do Hiparidi, que é um xavante, que na época surgiu assim como uma liderança em São Paulo e eu fui conhecê-lo, eu soube que ele ia dar uma palestra ou ia ter uma participação numa mesa, eu fui conhecer no Palas Athena, que é um instituto que dá oportunidade de várias culturas se manifestarem, um instituto de filosofia, que ficava na rua Leôncio de Carvalho se não me engano, próximo da Avenida Paulista, do Itaú Cultural, e lá eu encontrei uma senhora chamada Edméia Jafet, o Edson estava participando comigo, e ai através da Edméia eu fui apresentado para o Hiparidi, líder xavante e expliquei para ele pessoalmente o projeto e ele me deu os telefones dele e daí a gente começou a fazer contato e foi um contato bem frutífero. (Matuck - entrevista).
\end{abstract}

Nesse contexto, foi organizada uma vivência numa casa de campo em Igaratá, próximo a Jacareí, a 79 km de São Paulo. Na época, Artur Matuck disse num texto sobre esse encontro: "ao entardecer uma fogueira e danças xavantes ao redor. As mulheres se recusavam a dançar como índias, pés e mãos juntas, saltando para frente e para trás. Podemos dançar como homens disseram desobedecendo". Assim, as danças circulares foram pela noite adentro,

o fogo criou um circulo místico recriado pelo vídeo luzes traços amarelos e rápidos. Ouvimos Hiparidi falar sobre cultura xavante conversar e cantar em xavante, assumia um poder que havíamos lhe concedido e nos dizia e nos dizia de espaços inexplorados do corpo, da dança, do movimento. Um chocalho de cordas e penas amarrado na perna de Suzana denunciava uma mestiçagem, uma sexualidade marota. Ela se dizia descendente de uma índia que a família quis esconder. (Matuck - Namorar em xavante ${ }^{32}$ ).

Também foram programadas outras atividades para aquela noite, como uma exibição de um audiovisual sobre a cultura xavante monitorada por Hiparidi, enquanto uma oficina sobre pintura corporal foi realizada pelo jovem índio João Lucas Owau.

pintura corporal, cuidar do outro, desenhar, pintar, vermelho do urucum e da casa do artista, no rosto, na perna, no braço. Owau,

\footnotetext{
${ }^{32}$ Texto de Artur Matuck - intitulado "Namorar em Xavante" -, que não foi publicado.
} 
João, um ainda menino xavante, contador de mitos, artista e ingênuo, tinha muita paciência para olhar e pintar a Paula que ficou descansando quase todo seu corpo traçado de vermelho vivo. todos rindo. um colar de uma só pena esticada para trás do pescoço nos deixava extravagantes presas do olhar do vídeo como também as mulheres feito índias pintadas de vermelho e preto imagens de uma alegria cheia de sol. (Matuck - Idem).

Outro foco de interesse para os participantes do Projeto Perforum eram as histórias orais que os índios contavam, verdadeiras ou míticas, ou misturando mito com realidade, que muito impressionavam os ouvintes brancos.

Nós A'uwẽ, somos um povo de história oral, não tínhamos escrita. De geração em geração, transmitimos os costumes, as histórias do nosso povo, as histórias das famílias, as histórias do dia-a-dia e os conhecimentos sobre o mundo. Depois do contato com o mundo dos brancos foram produzidos registros escritos sobre nossa cultura, por pesquisadores, religiosos e outros não-índios. Foram estes também que colocaram em letras a nossa língua. (Top'tiro, In: RURI'Õ, 2000, p. 5).

Nesse sentido, foi marcante o relato feito pelos índios que acabavam de fundar uma nova aldeia, chamada Abelhinha (Idzốuhu), durante a apresentação de um audiovisual - "alguns eslaides relatam a fundação da nova aldeia, criada segundo a arquitetura tradicional, ao lado do rio, as casas em círculo, muito longe da ação dos missionários que insistiam que não se falasse xavante" (MATUCK, 2000). De fato, era uma história recente de uma família xavante que descontente com a situação num aldeamento junto a uma missão salesiana resolveram se deslocar para um outro lugar dentro da área indígena: "Para fundar uma aldeia, aconteceu reunião de manhã e a noite. Após o encontro o Tseretsu correu para caçar e procurar o local adequado para levantar a aldeia conforme a ordem de Top'tiro. Os filhos do Top'tiro ficaram contentes, queriam sair logo da aldeia de Sangradouro, porque e eles queriam preservar a organização social xavante" (RURI'Õ, 2000, p. 7).

Esta história se passa no final do ano de 1995, na aldeia de Sangradouro. A aldeia chama-se "Sangradouro" por influência histórica de missões religiosas. Sangradouro, no final da década de 40 , era uma missão salesiana, que abrigou grupos de xavante sem terra, perseguidos por fazendeiros ao doentes, após várias décadas de resistência na luta pelos seus territórios. A missão contribuiu com os xavante para a resolução de muitos problemas decorrentes do contato com o os brancos, apoiando por exemplo a demarcação de suas terras. Mas por outro lado, buscou introduzir os valores da sua 
religião, interferindo na organização social das aldeias. (Idem).

Os fundadores da nova aldeia desejam revitalizar as formas de vida tradicionais. "A comunidade de Idzô'uhu realiza seus trabalhos de forma coletiva, principalmente na roça de toco, conforme foi combinado. Os homens fazem a primeira roçada e em seguida derrubam as árvores. Menos os pés de Jatobá que são encontrados no meio da roça, pois as crianças e mulheres grávidas apreciam o gosto da fruta do Jatobá (Idem, p. 19). No entanto, os xavante da aldeia Abelhinha sabem que não podem viver mais no isolamento, assim tentam incorporar novos hábitos e conhecimentos dos brancos que não entrem em conflito com o seu modo de vida tradicional.

A comunidade de Idzô'uhu percebeu que todo mundo estava trabalhando muito. Por isso as pessoas sentiram a necessidade de formar um campo de futebol para se divertirem após os serviço, ou no fim de semana, sem deixar os hábitos tradicionais da aldeia. Atualmente a comunidade dá boas vindas aos hábitos dos brancos, desde que não atrapalhem ou prejudiquem a estrutura social da aldeia. A escova e a pasta de dentes já fazem parte do cotidiano da aldeia, principalmente dos alunos. Manter a aldeia limpa também é um hábito novo porque o lixo é diferente hoje em dia, parece um exagero mas é uma realidade. (Idem, p. 25).

Por outro lado os mitos tradicionais também interessavam aos paulistanos do Projeto Perforum - principalmente um deles contado pelo jovem índio João sobre uma personagem bastante interessante, uma estrela que se converte em mulher e seduz um adolescente xavante. Essa personagem revela traços que a caracterizam como uma estrangeira, portanto o mito seria uma alusão ao contato entre os xavante e o mundo exterior, principalmente a sedução que os jovens índios podem sofrer quando expostos ao entorno modernizado.

Era noite. Os Wapté ${ }^{33}$ estavam no Warã ${ }^{34}$, deitados nas esteiras, de barriga para cima. Dois î'mo ${ }^{35}$ começaram a conversar:

- Olha, î'mo! Olha aquela estrela vermelha! Que bonita! Como ela brilha!

- Ah! Não, î̃mo... Aquela estrela mais brilhante é a mais bonita.

- Não, î́mo. Aquela estrela mais brilhante é a mais bonita. Se ele pudesse descer! Se ela gostasse de mim! Se viesse ficar comigo! (SEREBURÃ, 1998, p. 29).

Adolescente em língua xavante.

Centro da aldeia em língua xavante, onde se realizam reuniões e rituais.

Companheiro do clã oposto, escolhido pelo pai do wapté por afinidade. 
Na verdade, o desejo do adolescente xavante se realiza, a estrela desce do céu e vem deitar-se com ele na esteira. "A estrela ouve o pedido do wapté e desce para atender o seu desejo. Como uma moça muito bonita ele se deita ao lado dele na esteira. Os dois ficam namorando, até de manhã..." (Idem). E a história continua até que o menino sobe ao céu através de uma palmeira de buriti que "havia crescido tanto que já não se via mais suas folhas. Tinham alcançado o céu, penetrando o algodão das nuvens" (Idem, p. 36). Vai ao encontro da namorada-estrela, deixando para trás a mãe e o irmão.

Os dois, mãe e filho, vão correndo até onde o wapté havia subido. Quando chegam, vêem a palmeira. Retinha. Alta, muito alta, muito alta. Naquele tempo o céu era baixo e a wa'a wede ${ }^{36}$ tocava o céu. A mãe se sentou ao lado da palmeira e chorou.

Chorou, chorou, chorou.

Triste, a mãe fica esperando... Tinha esperança que o filho voltasse um dia.

Quando o wapté chegou no céu, seu quarto já estava preparado dentro da casa do sogro. Lá ele construiu a sua família.

O tempo passou, passou, passou...

Ele tinha muita saudade da sua mãe, do seu pai... Avisou o sogro que ia voltar par visitar a família. Trouxe uma cabaça bem grande cortada ao meio. Dentro da cabaça muito mo'õni e ubdi. Os sogros haviam preparado para firmar o compromisso dos filhos. Esse foi o primeiro ato firmado responsabilidade entre os sogros.

O rapaz conta para os pais com era sua vida no céu e vai embora.

Vive para sempre com sua esposa-estrela, no céu.

Assim foi a primeira história de amor.

Essa é a história do wapté que subiu para o céu e nunca mais voltou. (Idem, p. 37)

$\mathrm{Na}$ verdade, os índios xavante, espalhados pelos cerrados do Brasil Central, não sofreram diretamente com a chegada dos portugueses a Porto Seguro. Com a aproximação dos brancos, eles foram se afastando cada vez mais rumo ao interior do Brasil. O contato com esses índios só foi ocorrer efetivamente nos anos 60 quando ficou famosa a foto feita por Jean Manzon de um xavante atirando com arco e flecha na direção de um avião que sobrevoava a aldeia:

a revista Cruzeiro acompanhou a conhecida Expedição RoncadorXingu e a pacificação dos índios xavante, também com várias reportagens. Nesse caso atribui-se valor imagético à resistência daquele grupo, na conhecida fotografia em que aparecem atirando

${ }^{36}$ Palmeira de buriti. 
flechas em direção ao avião de onde são fotografados por Jean Manzon. Entretanto, no processo de contato acabaram por se render ao grande pássaro, como na foto de José Medeiros, em que um Xavante se abraça às rodas de uma aeronave ${ }^{37}$.

A partir dessa época o Brasil Central passa a ganhar relevância nas políticas públicas, principalmente com a construção de Brasília e a abertura da nova fronteira agrícola, o que para o xavante significava o fim do isolamento, que até então tinham conseguido manter, embrenhando-se pelo cerrado.

apenas em meados dos anos 1960 que o "contato" xavante completou-se. Àquela altura, todos os grupos xavante já haviam estabelecido ou admitido relações pacíficas com representantes da sociedade nacional, mas os modos e os momentos em que o fizeram foram distintos. Esgotados pelas doenças, pela fome e pelos conflitos com colonos, alguns grupos dirigiram-se a postos do SPI; outros buscaram refúgio em missões salesianas ou protestantes ${ }^{38}$.

Desde então, os contatos têm sido intensos, repetindo-se de certo modo os abusos da época dos descobrimentos. Foram implementadas políticas de ocupação dos chamados "espaços vazios" do Centro-Oeste e da Amazônia Brasileira. Com isso os xavante foram profundamente afetados.

Nos anos 1960 e 70, por incentivos fiscais do governo, destinados a fomentar a colonização e o desenvolvimento econômico em larga escala da região, colonos e fazendeiros chegaram por lá. O acesso a porções do território tradicional do povo Xavante envolveu, muitas vezes, fraudes. Sabe-se de casos em que, para disponibilizar terras à produção capitalista, autoridades alteraram mapas e atestaram a ausência de habitantes indígenas. Imensas extensões de monocultivo agrícola - de início, sobretudo arroz de terras altas; mais recentemente, soja - foram implementadas pelos fazendeiros, que também desmataram vastas áreas de cerrado com vistas à criação de gado. (ISA).

Intensas lutas pela recuperação de terras ancestrais, bem como esforços para demarcar as terras que ainda continuavam sob seus domínios - em alguns casos, solicitando o aumento dos seus limites - caracterizaram o final da década de 1970 e o início da de 80 .

A partir de meados dos anos 70 , muitas das famílias que haviam deixado as terras habitadas no período pré-contato para buscar

37 Luis Nassif Online, disponível em: http://www.advivo.com.br/blog/luisnassif/o-indio-na-fotografiabrasileira - acesso em 23 de Fevereiro de 2013.

38 ISA - Povos Indígenas no Brasil, disponível em: http://pib.socioambiental.org/pt/povo/xavante/1645 
refúgio em missões ou postos do SPI começaram a retornar para seus territórios de origem. Ao fazê-lo, encontraram as áreas ocupadas por colonos ou por fazendeiros dedicados ao agronegócio de larga-escala. Em alguns lugares, os colonizadores não-índios haviam estabelecido cidades inteiras. Quando líderes xavante se puseram a reivindicar direitos sobre suas terras, a violência, concreta ou como ameaça, irrompeu em muitas localidades. (ISA).

Portanto, as relações dos xavante com a sociedade brasileira envolveu sempre muitos conflitos, daí o interesse dos índios participantes do Projeto Perforum de se relacionar com os brancos (warazu), buscando uma outra forma de convívio. É preciso recordar o passado recente dessa população do Brasil Central, como faz a antropóloga Aracy Lopes:

A partir da década de 70 , como já acontecera nas 40 e 50 , os Xavante ocuparam com frequência as manchetes dos jornais. Naqueles idos, eram notícias de selvagens que flechavam os aviões que ousavam sobrevoar suas aldeias nos confins da até então inexplorada Serra do Roncador ou que, heroica e dramaticamente, defendiam sue território da invasão de colonos brancos, de expedições de pacificação enviadas pelos órgãos oficiais, de missionários de todos os tipos. A partir de meados da década de 40 chegam às cidades as boas novas dos contatos pacíficos. A região estava aberta à colonização e ao progresso; os selvagens destemidos, afinal, amansados. A década de 50 divulga notícias das expedições, punitivas, dos massacres, das transferências de territórios, das epidemias que dizimaram mais da metade da população Xavante. (SILVA, 1986, p. 29).

Depois desse trágico preâmbulo dos contatos entre os Xavante e a sociedade brasileira, os Xavante mudam a sua tática de aproximação com os brancos. "Aparecem, nos anos 70, as novas notícias. Depois de alguns anos fora do noticiário cotidiano, os Xavante voltam às manchetes. Não mais, porém, com as flechas e as bordunas atirando aos aviões. No seu lugar, armas mais eficientes na defesa de seus interesses e no combate às invasões e ao desrespeito á sua liberdade" (Idem) Aracy se pergunta que notícias nova seriam essas, e responde:

São as que mostram o processo de demarcação das Reservas Xavante, sua disputa por terras com posseiros e com grandes empresas agropecuárias incentivadas e subsidiadas pela política desenvolvimentista do Estado Brasileiro. São notícias que fazem o leitor pensar no Xavante com um índio "consciente", reivindicador, sabedor do valor de seu próprio universo cultural e, pronto a defendê-lo; conhecedor de seus direitos e pronto a preservá-los ou 
recuperá-los; em índio não mais enfeitiçado pelo mundo da civilização ocidental e que reage à dependência e à dominação, buscando formas mais justas de relacionamento entre os dois mundos. (SILVA, 1986, p. 30).

$\mathrm{Na}$ verdade, os índios xavante estavam dispostos a participar do Projeto Perforum, no intuito de mostrar a sua cultura. Naquele momento, acabavam de fundar a Associação Xavante Warã, composta de índios da aldeia Abelhinha, na terra xavante de Sangradouro (Mato Grosso). O nome dessa associação foi retirado da assembleia geral da aldeia.

\begin{abstract}
O warã é o espaço central da aldeia, o pátio. No warã acontece a assembleia geral da aldeia, onde todos os anciãos e homens maduros se encontram e discutem a cerimônia do wai'á, a caçada e tudo mais que é importante. Os conselhos dos velhos são transmitidos no warã. As decisões são tomadas lá. Esse warã é dirigido pelos anciãos dos dois clãs, poredza'õno e öwawé. O velho do clã poredza'õno dirige a discussão e o conselho. E o velho do clã öwawé responde ao outro velho, ou completa o seu pensamento ${ }^{39}$.
\end{abstract}

As vivências que os índios xavante realizaram como parte do Projeto Perforum se inspiravam nessa assembleia da aldeia, "warã", em torno a fogueira, onde se dançava e contava histórias.

(...) eu lembro que teve cenas assim, teve uma fogueira, teve danças em volta da fogueira, teve também uma questão de namoro interativo entre homens e mulheres, ficavam os homens de um lado as mulheres do outro e era uma brincadeira que ele sugeria das pessoas se aproximarem e mexerem nos cabelos. Era uma coisa assim bem poética, bem legal, interessante. (Matuck - entrevista).

Pode-se dizer, então, que os índios xavante que participaram do Projeto Perforum compreenderam muito bem a proposta inicial do projeto de estabelecer um diálogo de civilizações. Naquele período uma série de eventos e publicações tentavam divulgar a cultura xavante como o livro publicado pelo Senac Wamrêmê Za'ra - Nossa palavra: mito e história do povo xavante. Esse livro registra a palavra de um grupo dos homens mais velhos da aldeia Pimentel Barbosa.

Esses velhos sabem que estão vivendo outros tempos, que o isolamento já não é possível e que podem usar o conhecimento e a tecnologia dos warazu, a seu favor. Novas armas na sua luta de

39 Associação Xavante Warã, disponível em: http://wara.nativeweb.org/. Acesso em 24 de Abril de 2013. 
afirmação como povo.

Este livro é fruto desse pensamento. Os velhos sabem que vão embora. Que o tempo que têm para acompanhar os meninos, que mais uma vez estão no Hö, a casa dos adolescentes, será curto. Talvez estejam em pé para a cerimônia de furação de orelhas. Talvez nem todos estejam lá.

E esses velhos sabem que sua voz registrada pelo gravador, que as palavras transformadas em tinta sobre o papel podem sobreviver ao seu tempo e chegar lá na frente, de um outro jeito mágico, guardando o conhecimento e a tradição para as futuras gerações.

Por isso estas histórias, as narrativas ancestrais de um tempo de todas as criações, os relatos do passado mais remoto, do tempo dos conflitos e do contato com os brancos. (SEREBURÃ, 1998, p. 9).

Para melhor entender o interesse dos índios Xavante em compartilhar a sua cultura com os brancos de São Paulo é necessário situar o momento histórico pelo qual estava passando aquele grupo, principalmente o impacto que a modernidade teve sobre as suas tradições naquele momento. "Os índios Xavante seguem dando muito valor a suas tradições. Eles parecem conscientes da importância da manutenção de seus costumes na luta pela sobrevivência. Entretanto, a influência das culturas branca e africana não passa desapercebida" (LEEUWENBERG, 1999, p. 55) Assim eles não se mostram indiferentes às transformações de seu entorno, mas procuram participar das mudanças tecnológicas.

O rap e a música de discoteca têm muito prestígio junto aos rapazes, ao passo que a sertaneja tem a preferência dos de meia idade. Toda essa variedade de música se faz ouvir graças ao grande número de gravadores e aparelhos estereofônicos portáteis encontrados em praticamente todas as unidades familiares.

Os Xavante são muito afeitos a esses aparelhos e cultivam o hábito de gravarem suas cerimônias para avaliação posterior da qualidade das cantorias. Orgulhosos de sua música, os jovens Xavante ouvem repetidas vezes essas gravações, muitas vezes cantando junto com a máquina. As histórias antigas contadas pelos velhos vêm também sendo registradas em cassetes para conhecimento das gerações futuras. (LEEUWENBERG, 1999, p. 55).

Além disso, aqueles índios xavante também queriam estabelecer contato com pessoas que pudessem ajudá-los na defesa do cerrado brasileiro, "Ró" na língua xavante, do qual dependem para a sua sobrevivência física e cultural. 
O Xavante depende do cerrado e o cerrado depende do Xavante. Os animais dependem do cerrado e o cerrado depende dos animais. Os animais dependem do Xavante e o Xavante depende dos animais. Isso é o Ró. Ró significa tudo para os caçadores Xavante: o cerrado, os animais, os frutos, as flores, as ervas, o rio e tudo mais. Nós queremos preservar o Ró. Através do Ró garantiremos o futuro das novas gerações: a comida, os casamentos, os rituais e a força de ser Xavante. Se estiver tudo bem com Ró continuaremos a ser Xavantes. O caçador anda no Ró e aprende a amá-lo. As mulheres aprendem a amá-lo porque o casamento depende do Ró e porque também andam lá para pegar as frutas ${ }^{40}$.

Com o objetivo de preservação do meio ambiente do cerrado, a Associação Xavante Warã lançou, em 1999, a campanha "Tsõ'rebtunã ró hã: Salve o cerrado pela preservação do cerrado e da cultura xavante":

Com esta campanha, a Associação Warã buscou demonstrar a importância do cerrado para o povo Xavante e informar sobre a necessidade de preservação deste ecossistema. As fotos de satélite obtidas para o laudo de impacto antropológico e ambiental da TI Sangradouro, comprovaram ainda, que os fazendeiros vizinhos não estavam respeitando a lei 49.141 de 29/12/1967 (Art 7o Parag. Único), segundo a qual não se pode desmatar mais do que $80 \%$ das áreas para plantio no cerrado. O cerrado está entre os 10 ecossistemas ameaçados mais ricos em biodiversidade do mundo (estimada em $5 \%$ da fauna e flora mundiais). Foram organizados, em prol da causa, um abaixo assinado, uma exposição e dois eventos culturais, com palestras, projeção de audiovisuais, shows de artistas convidados e apresentações da cultura Xavante. (Warã)

Como se pode observar, havia uma certa sinergia entre os objetivos implícitos no Projeto Perforum e as iniciativas dos índios xavante naquele final de século.

uma vez a gente recebeu um telefonema, do Hiparidi, da família dele, dos amigos dele, e falando assim: "olha, hoje à noite a gente queria que vocês viessem aqui" era na Rua Fábio, na Lapa, "que é o aniversário do Hiparidi e a gente queria que vocês viessem visitar a gente tudo, não é?" E daí eu e a Cristina fomos, e daí chegou lá "Parabéns Hiparidi, não sei o quê", e ele falou assim: "não é meu aniversário". "Não é aniversário do Hiparidi. É que a gente sabe que se a gente chama vocês para discutir questões políticas, sociais, vocês normalmente não vem, mas se a gente fala que é um aniversário vocês se sentem obrigados a vir, então a gente falou que era aniversário para você ver o que está acontecendo na aldeia, que é uma coisa importante" Daí abriram uma fotografia aérea e falou

40 Associação Xavante Warã, disponível em: http://wara.nativeweb.org/ - acesso em 05 de Abril de 2013. 
assim: "essa é a área da aldeia, e está sendo invadida pelos plantadores de soja. Então, o verdadeiro motivo da reunião era: "olha, a gente precisa que vocês colaborem na nossa luta pela nossa terra, pela nossa autonomia como tribo, mas por isso que a gente convidou vocês aqui não foi por causa do aniversário." Aliás, os xavantes nem comemoram aniversário. (Matuck - entrevista).

Mas, infelizmente a troca cultural iniciada entre o Projeto Perforum e os índios xavante não foi levada adiante, além das vivências realizadas. O próprio vídeo sobre a vivência em Igaratá acabou não sendo finalizado, por falta de recursos para a edição. Os índios convidaram os participantes do Perforum a visitar a recém fundada aldeia Abelhinha, mas somente Edson de Oliveira e Suzana Moraes chegaram a ir para a área indígena em Mato Grosso, numa ocasião posterior.

Sim, foi você que me apresentou o Hiparidi, não é? E depois, nessa integração eu fui me aproximando, ele me convidou e na realidade ele convidou todo mundo para ir à aldeia, e você não sei por que acabou não indo, não é? Foi um grupo grande, não fui só eu, tinha uma professora antropóloga da PUC, Maria Helena foi também e a gente foi para conhecer justamente, e ele levou a sério essa coisa de mostrar a cultura dele, daí estivemos lá na aldeia, participamos de rituais, passeios na natureza mostrando as plantas que eles usam e também no dia a dia ali da aldeia, a gente ficou uma semana com ele. Isso foi nesse primeiro grupo. A Edmeia também esteve, mas foi numa época diferente da minha, ela foi num outro grupo. Ela também foi lá, é a Aldeia de Sangradouro, inclusive acho que teve um pessoal aqui, não é? Olha ai. É essa mesma Aldeia de Sangradouro, o Sérgio Baio, depois você pode contar o que aconteceu, mas... foi um grupo grande que esteve aqui? (Entrevista - Edson - anexo).

\section{Num estágio mais avançado do Projeto Perforum, já em sua fase de transmissões entre São Paulo e Florianópolis (Desterro), ainda ocorreu uma teleconferência, da qual participou o índio xavante Hiparidi Top'Tiro e o cacique da Comunidade Cafuza de José Boiteaux de Santa Catarina.}

o nosso objetivo era fazer conexões entre as culturas que não estariam participando das comemorações dos 500 anos da descoberta do Brasil, que seriam os índios e os negros brasileiros basicamente. Então ela franqueou o uso para a gente e começamos a realizar uma série de vídeo conferências e conforme as pessoas foram se agrupando e realmente realizando as vídeo-conferências, o nosso principal parceiro ficava em Florianópolis e a pessoa da Yara Guasque, da UDESC - Universidade de Santa Catarina se não me engano, ela era e imagino que ainda é professora lá no departamento de artes e ela aceitou participar, fez um grupo de pesquisa e criou digamos, uma estação terminal que ela colocou o 
nome de Perforum Desterro. (Matuck - entrevista).

Mas essa transmissão também não foi muito bem sucedida em termos de diálogo de civilizações. Pois, os dois índios não tinham muito o que dizer entre si, uma vez que vinham de ambientes completamente diversos, conforme relata Matuck em entrevista concedida à autora.

O Cafuzo era um cacique que era a mistura do negro com índio. E esse senhor foi encontrado pela Yara, no interior de Florianópolis, no interior do estado de Santa Catarina, veio até Florianópolis para participar de uma conferência com o Hiparidi, e essa conferência aconteceu aqui na Faculdade de Economia e Administração. Eu vi um fragmento da documentação dessa conferência recentemente, e uma coisa que me chamou a atenção e que eu acho que era uma certa inocência que a gente tinha na época, a gente tinha essa ideia de inovar a linguagem, recriar a linguagem da vídeo conferência e tudo o mais, e a gente trabalhava por algum motivo que eu não vou lembrar exatamente qual, a gente trabalhava com uma série de espelhos, e assim tinha o Hiparidi falando, o Cafuzo falando e tinha pessoas da nossa equipe com os espelhos assim atrás. Então hoje eu acho uma coisa ingênua e deslocada e seria assim a construção de uma imagem que na verdade desvia a atenção daquilo que aquela pessoa esta falando que devia ser o foco. (Matuck entrevista).

Uma outra referência cultural era a contribuição africana para a formação da nação brasileira. Mais uma vez, o olhar retrospectivo assume um ponto de vista crítico.

Negroes had been imported into Portugal at least since 1433 , and by
the mid-sixteenth century the Portuguese were well acquainted with
the West African coast and its inhabitants. The Negro proved well
adapted to the tasks required by the colonists. Furthermore, the
troublesome reservations about using Indians as slaves rarely
extended to the use of Africans. For those reasons a forced migration
of millions of Africans began in the mid-sixteenth century and
continued apace until 1850 . It is believed that the first Negroes
directly imported from Africa arrived in Brazil in 1538 . (..) In 1585 , out
of a total population of 57,000 there were some 14,000 African
slaves, a majority of whom were in Pernambuco. (BURNS, p. 37).

O ponto de vista do Projeto Perforum era de que, tal qual os europeus e os índios os negros também participaram da formação da nação brasileira, no entanto, raramente são vistos com construtores do Estado Brasileiro, quando muito são 
encarados como vítimas de um processo perverso, enquanto a sua cultura é considerada como pitorescamente folclórica. São muitas vezes julgados como preguiçosos, quando a maior contribuição dos negros na construção do Brasil foi justamente com o seu trabalho.

Doubtless the Negro's major contribution was his labor. His strong muscles supported Brazilian civilization. He brought with him or learned in the New World many skills essential for the grouth of Brazil. He was the carpenter, painter, mason, jewler, sculptor, locksmith, tailor, cobbler, and baker. He made technical contributions in metallurgy, mining, cattle-raising, and agriculture. (Burns, p. 40)

Nesse contexto tivemos, também no formato de teleconferência "a conversa entre Elisabete Pinto do Fala Preta em São Paulo que abordou a questão da mulher negra na prostituição" ${ }^{41}$. O Fala Preta é uma ONG dedicada a "eliminação de todas as formas de discriminação e violência, especialmente a discriminação étnico-racial e de gênero",

Fundada em abril de 1997, a ONG Fala Preta foi criada com o objetivo de promover o desenvolvimento humano sustentável buscando a eliminação de todas as formas de discriminação e violência, especialmente a discriminação étnico-racial e de gênero, com base nos princípios éticos da igualdade, equidade e justiça, na promoção da qualidade de vida e no respeito aos direitos humanos e reprodutivos. Tem como meta fundamental a defesa dos direitos humanos e da cidadania da população negra, visando o acesso à educação e capacitação de recursos humanos e à qualidade de vida através de padrões sustentáveis de produção, consumo e serviços adequados de saúde, incluindo sexualidade, saúde reprodutiva e saúde mental, saneamento básico, habitação e transporte ${ }^{42}$.

No entanto, essa vertente também não foi plenamente desenvolvida, não indo além do registro do depoimento de Elisabete Pinto.

o Perforum, no final, ele gostaria de ter sido mais amplo, não é, por exemplo, eu tentei contatos com Portugal. Eu queria discutir essa questão do negro e do índio, dos 500 anos do Brasil, supostos 500 anos do Brasil segundo os portugueses e a versão oficial da estória do Brasil enxerga que são os 500 anos do Brasil, eu queria discutir

\footnotetext{
41 ARAÙJO, Yara Rondon Guasque, TELE-EVENTO-PENSAMENTO: a imagem mediada na videoconferência e na telepresença

42 Fala Preta, site www.falapreta.org.br, acesso em 25 de Fevereiro de 2013.
} 
essa questão com artistas e intelectuais portugueses, e eu lembro que um professor de literatura portuguesa da USP que é um senhor português que eu fiz amizade com ele, chama Ernesto de Melo e Castro, ele chegou a ir para Portugal e eu não lembro se eu dei uma cópia do projeto e ele disse que falou com pessoas em Portugal e disse que ninguém estava interessado em participar de um projeto dessa natureza, porque idealmente teria sido interessante para o Projeto Perforum se tivesse havido vídeo conferências com Portugal, mas isso nunca foi possível. (Matuck - entrevista).

Portanto, contrariando princípios históricos que exigem que se permaneça no âmbito do que foi documentado, pode-se fazer uma análise não só aquilo que o Projeto Perforum conseguiu realizar na época, efetivamente, mas também o que poderia ter sido realizado com as tecnologias disponíveis na época.

\subsection{PERFORUM DESCOBRIMENTOS}

\section{- La Farinera del Clote}

Evento que teve como resultado a experiência de comunicação virtual realizada entre jovens de Barcelona, Espanha e de Itapecirica da serra, Brasil. Coordenado pelos professores Artur Matuck da Universidade de São Paulo e a dra. Hiliana Reis, da Universidade Paulista - UNIP. A ideia surgiu quando Artur Matuck esteve em Barcelona e organizou um evento no centro cultural "La Farinera del Clote $^{43 ",}$ onde havia uma tevê comunitária que trabalhava com uma população de ciganos. Depois disso, houve um evento em São Paulo, que teve lugar na Estação Ciência.

Os participantes foram desafiados a pensar sobre suas próprias identidades e a dos outros, o lugar do diferente e a construir imagens e conceitos a partir da expressão individual e coletiva.

Curiosamente a língua não representou nenhuma barreira, pois houve comunicação e diálogo.

O local era uma antiga reivindicação do bairro do Clot, em Barcelona, que além de manter o patrimonio cultural de uma antiga fábrica de farinha do início do

43 O local era uma antiga reivindicação do bairro do Clot, em Barcelona, que além de manter o patrimonio cultural de uma antiga fábrica de farinha do início do século $X X$, nasce da vontade de atender às necessidades educacionais e culturais do bairro. 
século $X X$, nasce da vontade de atender às necessidades educacionais e culturais do bairro.

O uso das tecnologias era o ponto de partida para pôr em contatos jovens de diferentes culturas, desencadear um diálogo e para ouvir o que têm a comunicar.

Participaram da teleperformance:

- Da Estação Ciência: Eneida Rita Rossetti Fausto, Cauê Matos, Cecília Toloza, Dirce Pranzetti;

- Equipe Perforum São Paulo: Artur Matuck, Hiliana Reis, Ana Luisa Anker, Cesar Barros, Celso Fonseca;

Equipe de Barcelona do Centro Cultural La Farinera del Clot: Carme Mayugo I Majo, Vanessa Ros Vilar, Equipe TV Clot.

Os jovens que participaram da experiência em São Paulo, de ambos os sexos, com idades entre 9 e 25 anos, faziam parte da "Oficina Cultural Barracão da Cidadania" de Itapecirica da Serra (SP) - uma instituição municipal. Os rapazes eram grafiteiros e as meninas frequentavam as oficinas de dança e de arte. Já em Barcelona, participaram desta experiência jovens de 13 a 15 anos, que estudavam em Clot, próximo a "La Farinera". O público dos dois locais tinha uma característica em comum: eram pessoas de baixa renda, principalmente os de Itapecirica da Serra.

A primeira oficina, realizada no dia 29/04/2000, ocorreu na Estação Ciência com o objetivo de:

- $\quad$ apresentar o projeto aos jovens que se dispuseram a participar;

- $\quad$ preparar o roteiro a partir das questões levantadas pelos participantes;

- $\quad$ visitar e conhecer as atividades realizadas na Estação Ciência.

Foram apresentados o projeto e os monitores. O professor Artur Matuck explicou sobre as tecnologias, mostrando o funcionamento dos equipamentos. Infelizmente não foi possível utilizar o monitor de TV para ampliar a imagem, por problemas técnicos.

A segunda oficina, realizada no dia 13/05/2000, teve lugar no "Barracão da cidadania" em Itapecerica da Serra. Ana Luíza Anker foi a responsável pela gravação das atividades. 
Observou-se, a partir dos registros dos participantes, que o mundo das meninas e o dos meninos era muito diferente, embora a maioria se defina como pertencendo ao mesmo grupo.

Vejamos alguns trechos do que foi escrito por eles:

Pertencemos a uma igreja Carismática Girasonhos. Não saímos a noite, não gostamos de 'clubber', 'skatista', nem do pessoal que fica do lado de fora fazendo baderna, arrumando briga e querendo se mostrar. (Diane e Graziela)

Não gosto mais de brincar, gosto de desenhar e escutar música. Ajudo a minha mãe com meus dois irmãos. (Viviane)

Gosto de desenhar, estudar e em casa, gosto de brincar e andar de bicicleta. (Jéssica)

Por outro lado, os rapazes se definiram como skatistas e mencionaram os "clubbers", "função" e outras tribos.

Os 'clubbers' são pessoas que se vestem diferente, pintam o cabelo com cores esquisitas, tipo roxo, e ficam a noite inteira no salão arrumam briga. Os 'skatistas' usam o 'skate' como esporte radical, vestem-se de uma maneira completamente diferente: boné, bermudão; eles têm a turma deles. O 'função' é o cara que depende com quem ele está, é uma coisa: se ele estiver com um 'skatista', fala que é 'skatista' também, se estiver com um 'clubber', ele curte aquelas músicas e é 'clubber' também - não tem opinião própria. Aqui tem essas tribos. (Depoimento de um participante da oficina)

A terceira oficina, realizada no dia 16/05/2000, na Estação Ciência foi um teste para ver como funcionavam as transmissões entre São Paulo e Barcelona e também para que os jovens se apresentassem e elaborassem um roteiro final.

Foi utilizado o telefone viva-voz (o de São Paulo não funcionou pela ausência do cabo). Além disso, as imagens São Paulo-Barcelona não puderam ser vistas devido a um problema de raia. Mesmo assim, a experiência causou entusiasmo entre os participantes.

A quarta e última experiência ocorreu em 17/05/2000. Não foi possível conectar o videofone, que deveria transmitir imagens de São Paulo para Barcelona. Depois de muitas tentativas, eles optaram por enviar perguntas aos participantes via 
fax. Trocaram mensagens de alegria, solidariedade e cumplicidade. Houve também uma experiência com videofone
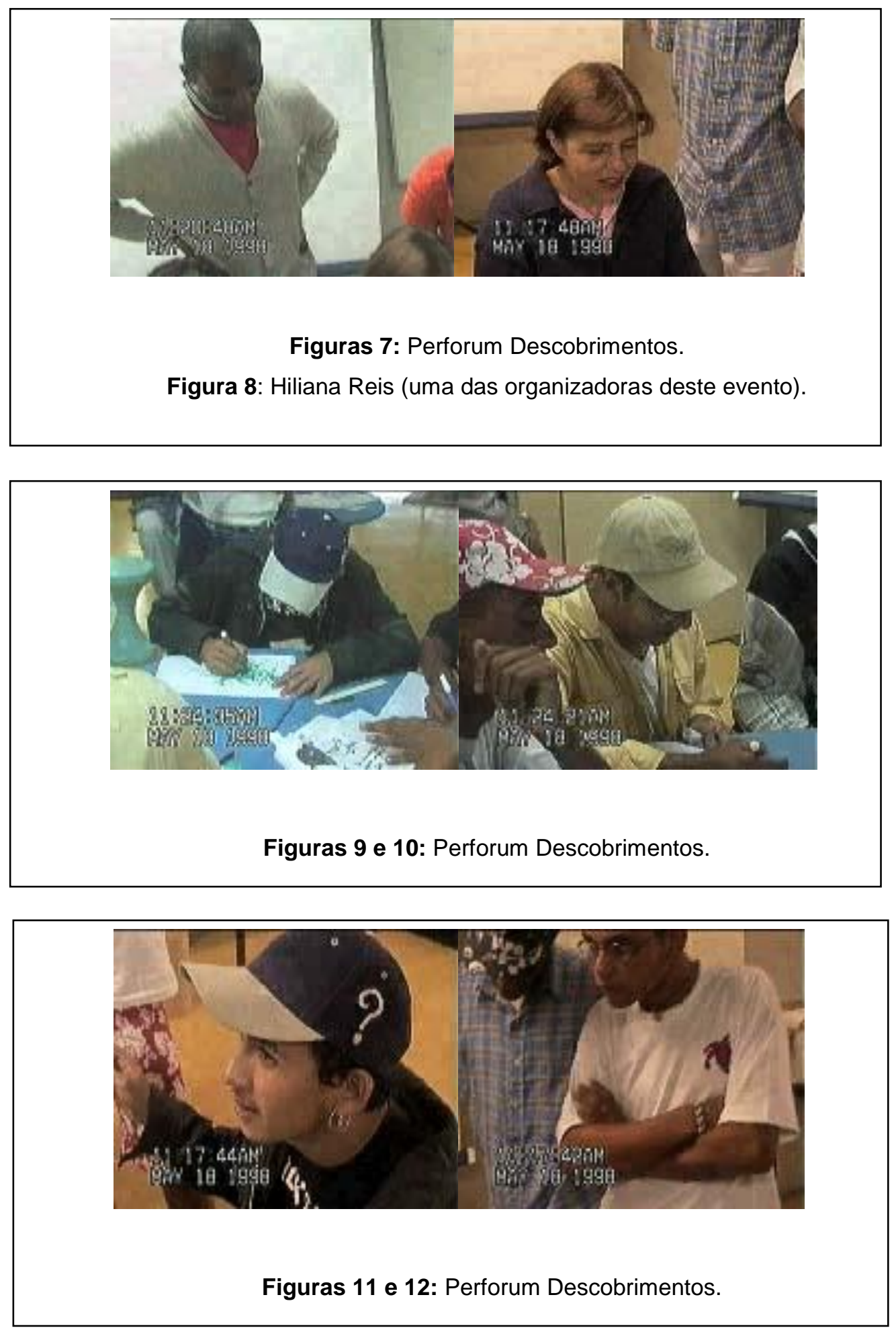


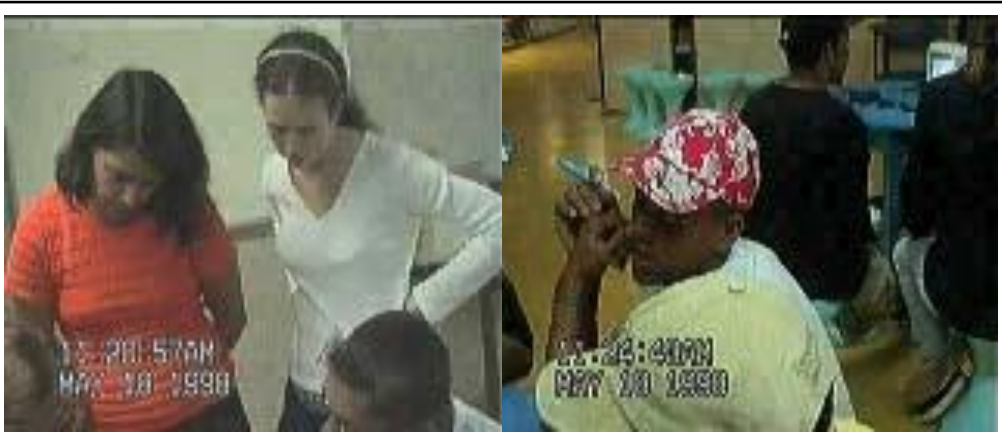

Figuras 13 e 14: Perforum Descobrimentos.

O fax possibilitou um efeito quase telestético, um entusiasmo mútuo pelo reconhecimento, pela identificação de algo em comum entre jovens de culturas, línguas e países distantes, que trocaram desenhos, textos, nomes, idades, gostos, preferências, mas que também insinuaram nestas mensagens a alegria, a solidariedade, a sensualidade, a cumplicidade, sentimentos e emoções que teimaram em transbordar a partir das mensagens mais simples.

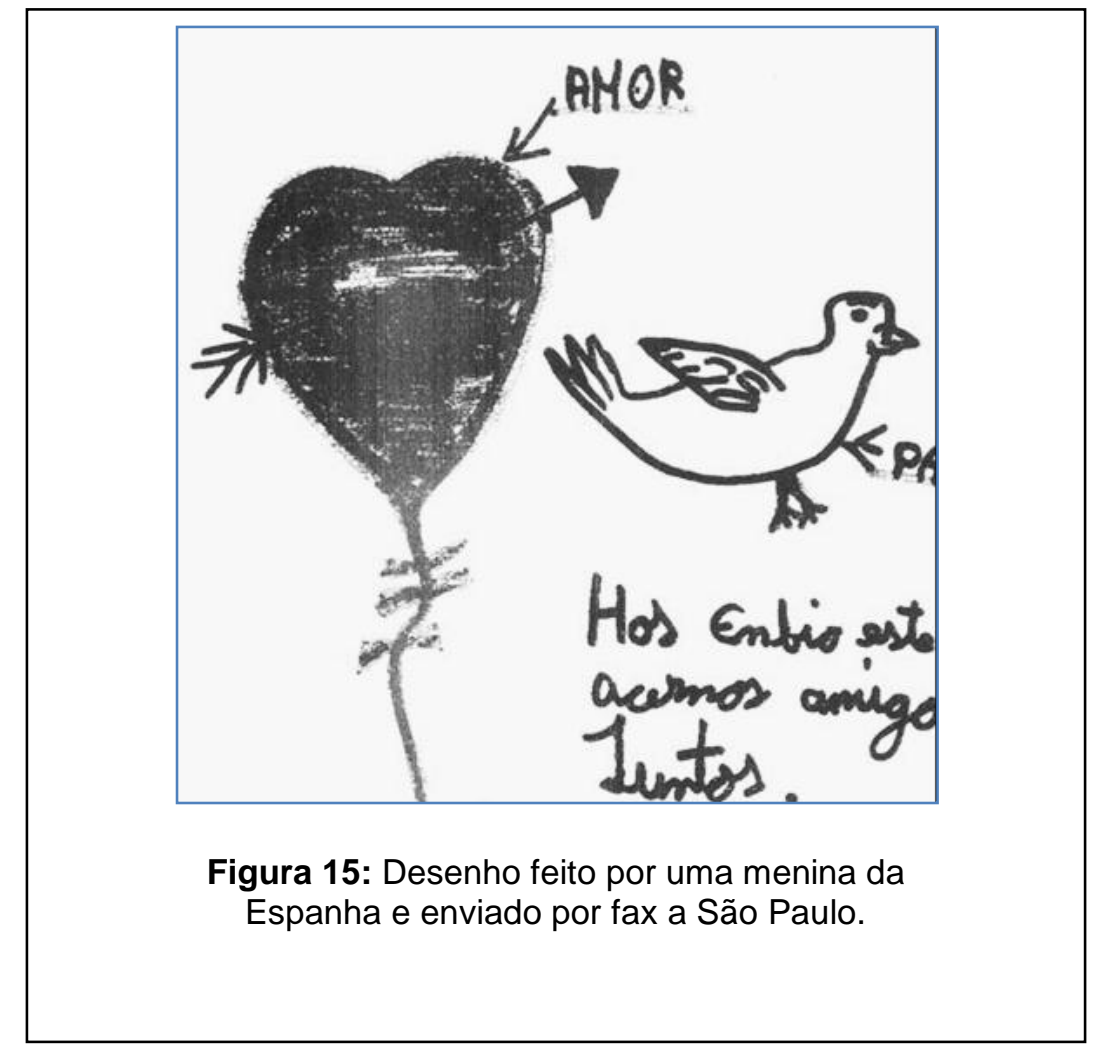


O desenho acima, enviado por uma menina de Barcelona, suscitou uma reação contrária num dos participantes (chamado Wagner): "Nós não estamos em guerra. Por que falar em paz?"

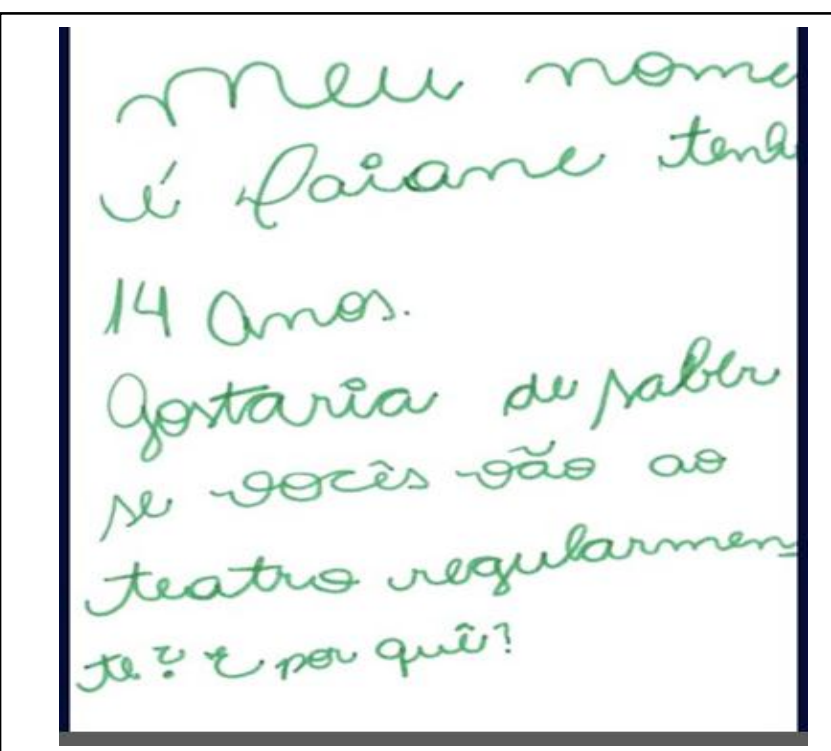

Figura 16: Texto elaborado por uma menina de São Paulo e enviado por fax para Barcelona.

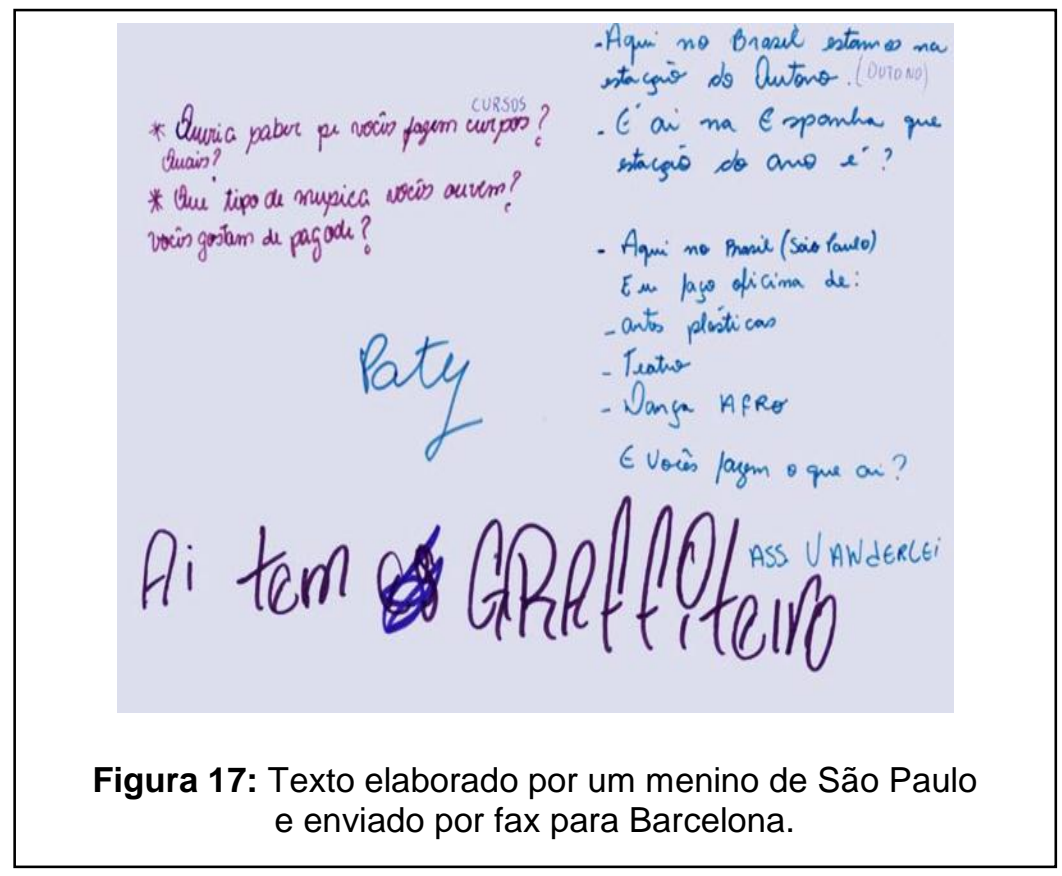


Pelas apresentações de modo geral, observou-se que o universo do grupo de Barcelona esteve centrado no colégio, nos amigos e na família. Eles disseram gostar de música "flamencos y rumbas, máquinas", cinema, discoteca, de passear com a família e de fazer excursões.

Enquanto as comidas prediletas dos brasileiros foram arroz com feijão, bife, batata frita e lasanha; os catalães mencionaram o pão com tomate, macarrão, pizzas e McDonald's.

As festas populares - "carrefocs" e os "diables" também foram mencionadas e representaram as tradições muito comuns na cultura catalã.

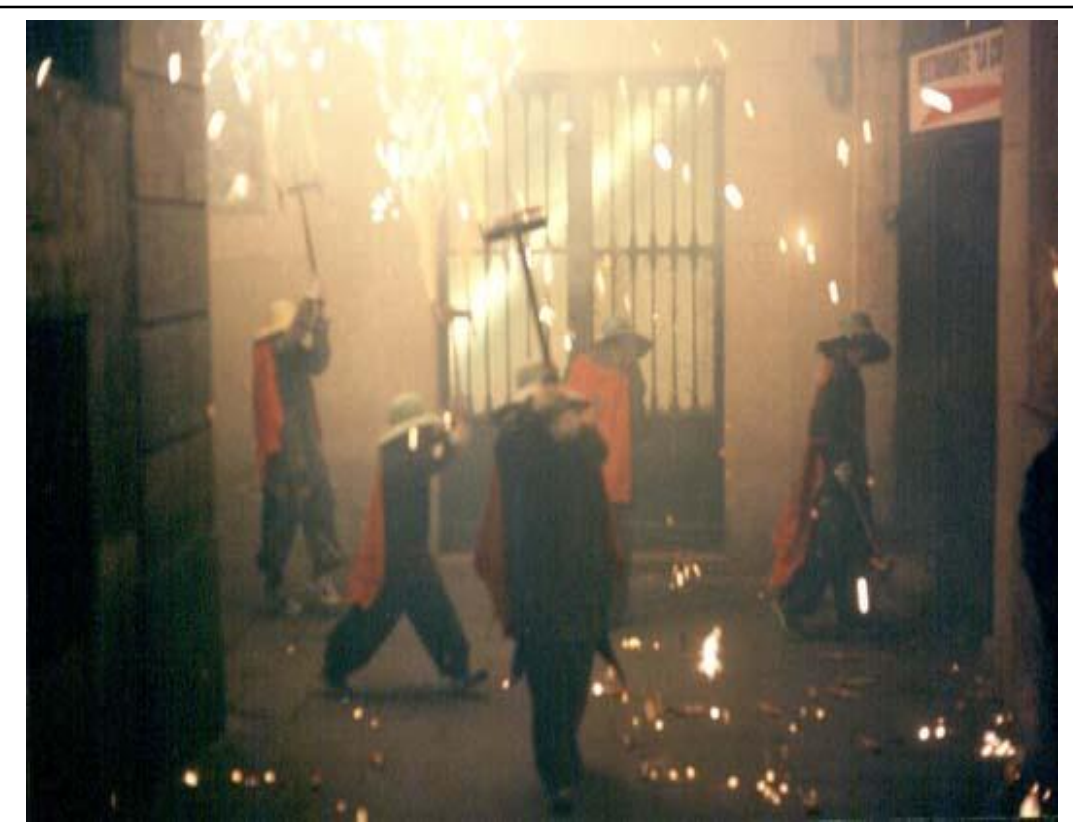

Figura 18: Festa popular catalã. 

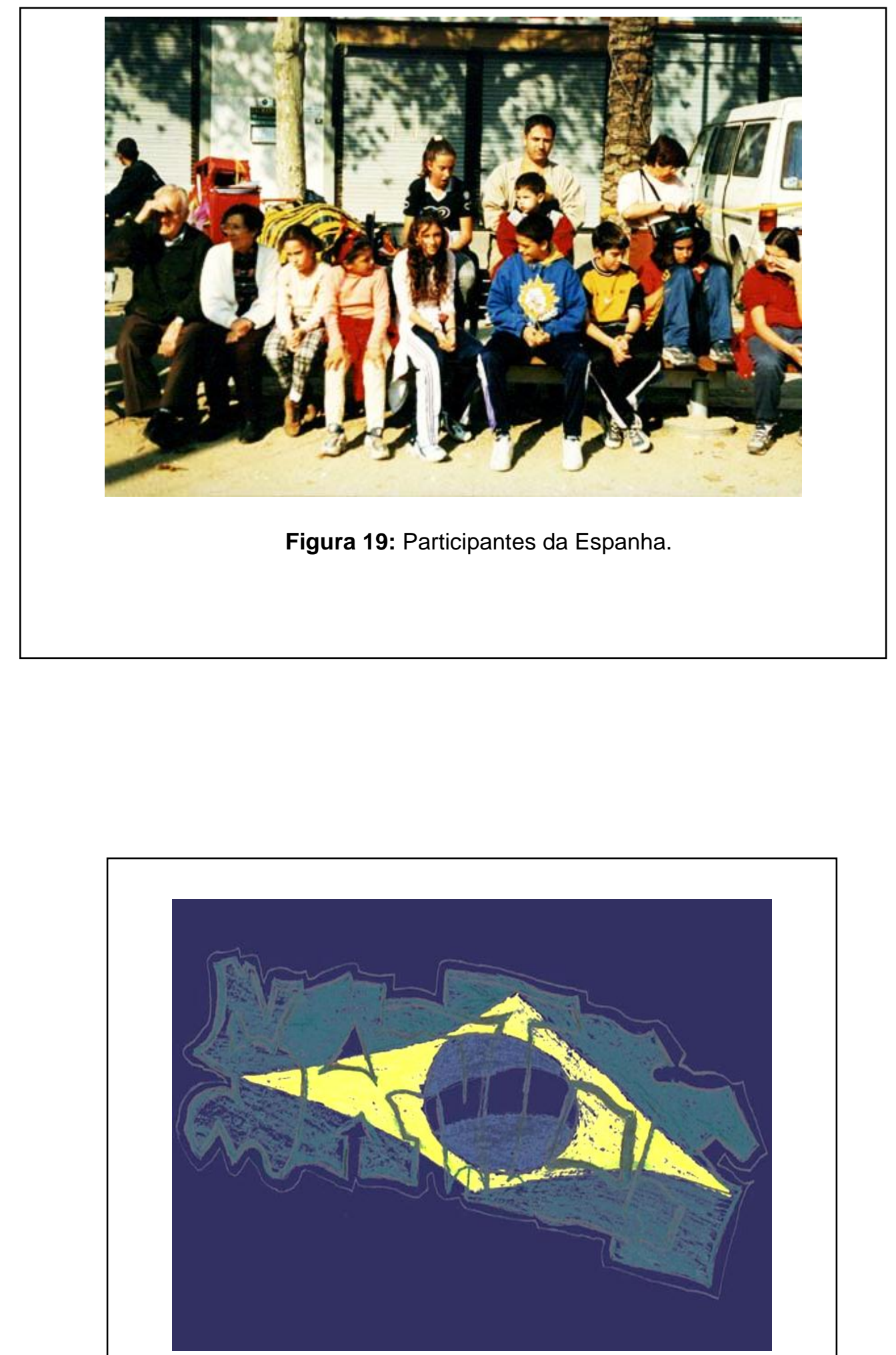

Figura 20: Grafite feito pelos participantes da São Paulo. 
A partir de um trecho da entrevista ${ }^{44}$ de Artur Matuck à Yara Guasque, podese perceber o que houve a partir destes contatos, especialmente quando do contato entre adolescentes que não falavam a mesma língua e estavam geograficamente muito distantes:

O projeto Perforum envolveu muitas pessoas, havendo um enriquecimento mútuo. O evento acabou criando uma reverberação, uma proposta de conscientização política, crescimento, empoderamento e a tecnologia poderia ser usada para esta humanização, desse projeto de congregamento a distância, de individualidades diferenciadas, pessoas singulares, cada uma com sua cultura, identidade própria e como podem encontrar o distante, outro, diferente e a partir daí construir um diálogo.

Eu acho que este esforço de se comunicar a distância não é só vencer a distância geográfica, na verdade ela acaba representando uma qualidade, a questão da expansão geográfica. A ideia de expandir geograficamente. A gente se sente que não habita uma cidade, região, mas habitando um país, planeta um mundo, se sente ampliado, expandido pela possibilidade tecnológica. Para mim representou todo esse evento, um evento telestésico, de expansão da consciência e por mais que tenha havido conflitos, erros, deficiências, houve muito progresso, evolução e conscientização.

\footnotetext{
${ }^{44}$ Entrevista disponível em http://webceart.udesc.br/perforum/. Acesso em 20 de Junho de 2013.
} 
4.

ANO 2000: AS COMEMORAÇÕES DOS 500 ANOS DO BRASIL

Essa noção mítica de que Portugal descobriu o Brasil. De que o Brasil só existe por causa de Portugal. É como o beijo que o príncipe dá para a princesa, não é? $\mathrm{Eu}$ acho isso interessante, essa estória de que nos contos de fadas a mulher só começa a existir quando o homem surge. De outro modo, a mulher esta num sono eterno, ela não tem identidade, não tem existência, é o homem que faz o toque mágico e a mulher começa a existir. Então, não sei, existe uma mitologia de que o Brasil existe por causa de Portugal ${ }^{45}$.

\footnotetext{
${ }^{45}$ Trecho da entrevista realizada com Artur Matuck (na íntegra, ao final da dissertação).
} 
Ao se aproximar o ano 2000, várias propostas começaram a ser apresentadas para a comemoração dos 500 anos do Brasil. A Rede Globo de televisão espalhou por todo país 28 relógios promocionais, com a contagem regressiva dos dias que faltavam para o 22 de Abril de 2000.

No entanto, os eventos que realmente vingaram acabaram por frustrar as expectativas criadas. Dentre os eventos destacamos aqui a agenda oficial, que incluía uma comemoração em Porto Seguro, Bahia, que terminou em protestos, seguidos de repressão policial. Além do evento que na nossa opinião foi o mais bem sucedido: a Mostra Brasil +500 , que teve lugar na Bienal de São Paulo, e que depois seguiu para os EUA e Europa. Um evento de grande repercussão graças a um esquema publicitário massivo.

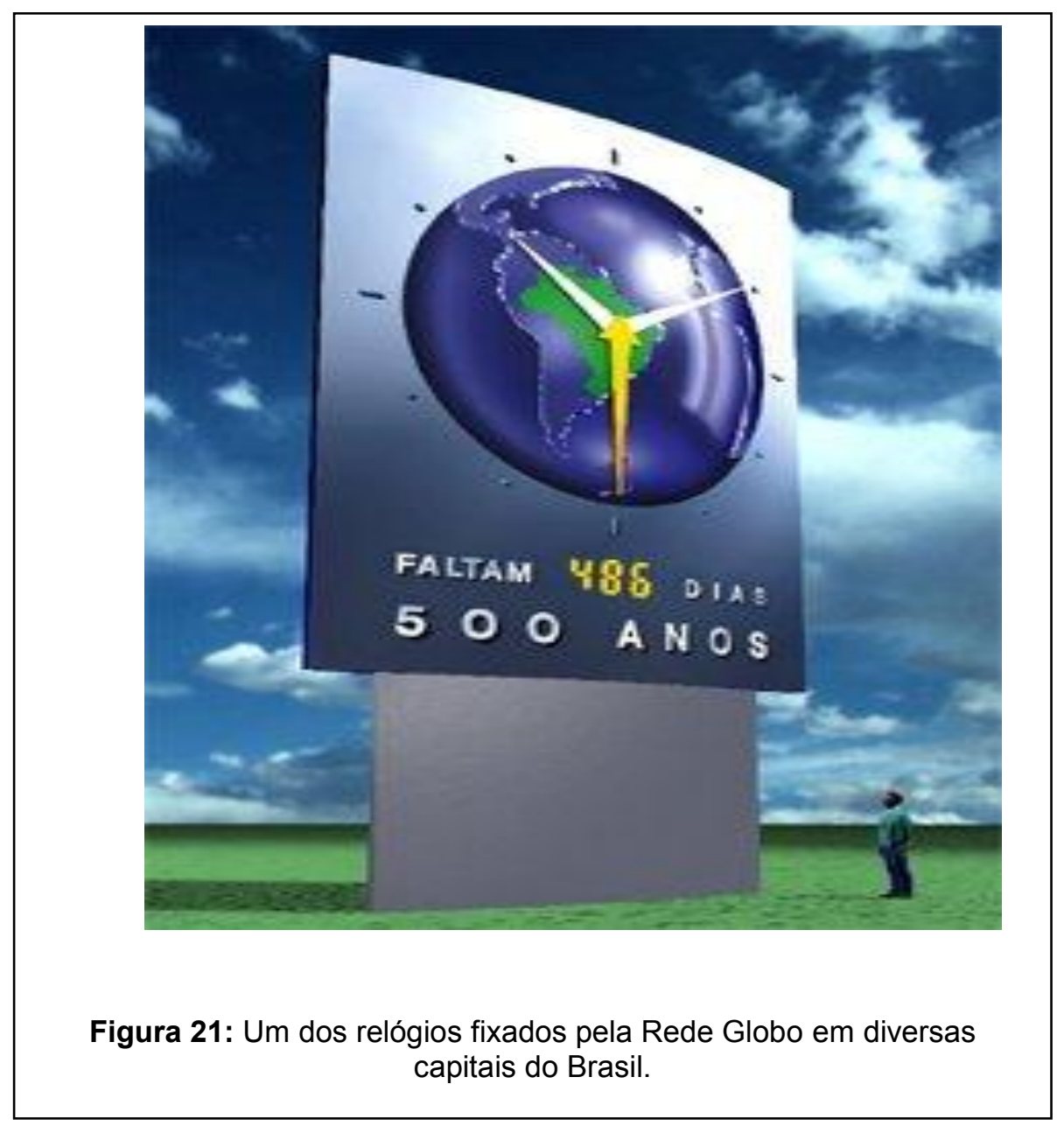




\subsection{COMEMORAÇÕES DOS 500 ANOS DO BRASIL EM PORTO SEGURO-BA}

O evento mais oficial das comemorações teve lugar em Porto Seguro, na Bahia, no local onde os portugueses chegaram há mais de 500 anos.

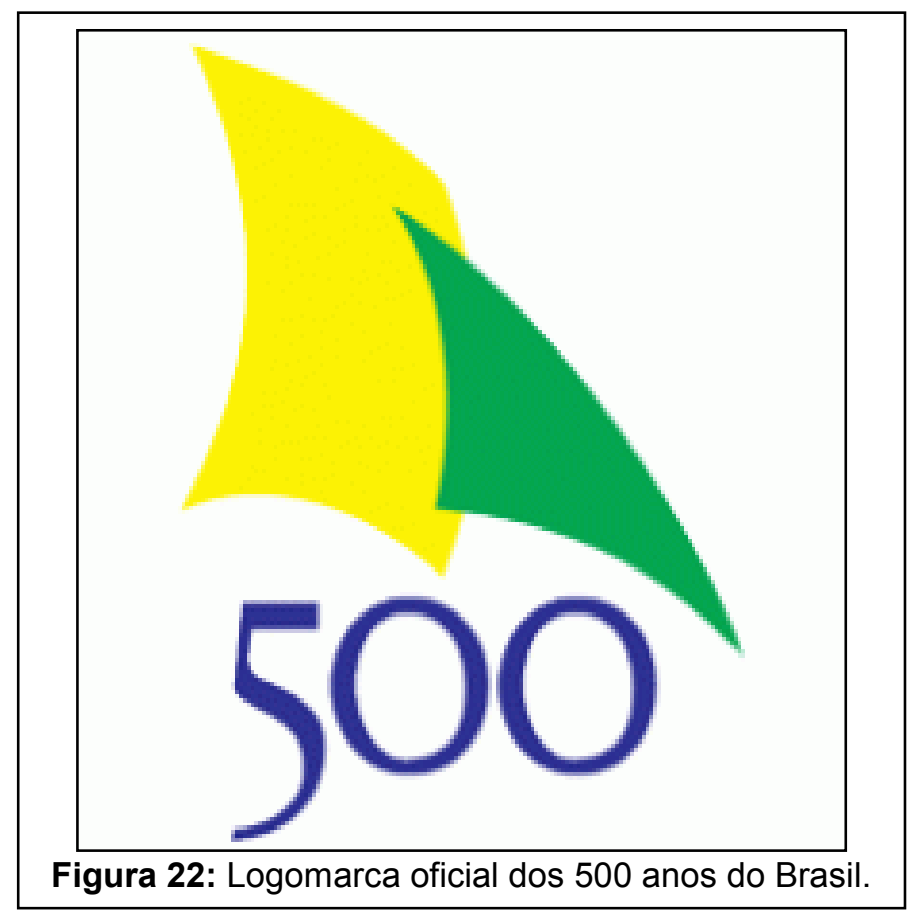

A logomarca oficial do $\mathrm{V}$ Centenário define-se pela presença de duas velas sobrepostas, uma em amarelo e a outra em verde, cores de nossa bandeira e que também representam a identidade nacional brasileira, acima do número 500 , pintado em cor azul, sobre um fundo branco.

Mas o que deveria ser uma data festiva transformou-se em contestação e divergência. Na manhã de 22 de abril de 2000 , ocorreram os primeiros confrontos entre manifestantes e a polícia de Porto Seguro - BA. Um grupo de sem-terras, estudantes e anarquistas chocou-se com a polícia, fechando uma das rodovias de acesso a Porto Seguro, a BR 367. Mais de cem pessoas foram presas. Mais tarde outra rodovia foi fechada por manifestantes, desta vez a BR 101, onde pneus foram empilhados e queimados.

Mais um constrangimento ocorreu desta vez com a réplica da embarcação que Pedro Álvares Cabral utilizou em 1500, chamada nau Capitânia, em comemoração ao V Centenário do Descobrimento do Brasil. Ela não conseguiu navegar até Porto Seguro por problemas técnicos, apesar dos gastos exorbitantes 
para a sua construção: mais que 2,5 milhões de reais. As causas desta falha foram ausência do lastro, fundamental para que a embarcação pudesse funcionar, o mau dimensionamento do mastro e a falha no motor (apesar das caravelas antigas não possuírem motor, na réplica foi colocado um). Deste modo, a embarcação teve que retornar a Salvador e não participou das festividades.

Em texto publicado no site do Tribunal de Contas da União ${ }^{46}$, de autoria do Instituto Memorabília e do Clube Naval, responsáveis pela construção da nau, lê-se:

Como parte do projeto do Instituto Memorabília, aprovado pela Comissão Nacional para as Comemorações do $\mathrm{V}$ Centenário do Descobrimento do Brasil, inclui-se a construção de uma réplica da Nau Capitânia da frota de Pedro Álvares Cabral. Associando-se a essa iniciativa, o Clube Naval, através de convênio celebrado com o Instituto Memorabília, assumiu o encargo de coordenar as atividades de construção da Nau, com vistas à sua participação nos eventos comemorativos dos 500 anos do nosso Descobrimento. (...) O Projeto Nau Capitânia, pelos seus objetivos, reveste-se de grande importância histórica, pela possibilidade de divulgação da origem da Nação Brasileira, e cultural, por se constituir em importante instrumento fomentador de uma consciência marítima no povo e, em particular, na juventude. Como se sabe, embarcações movidas a vela, de uma maneira geral, exercem grande fascínio sobre as pessoas. Uma embarcação desse tipo, construída nos moldes daquelas usadas na época do nosso Descobrimento, com o propósito de participar das comemorações do $\mathrm{V}$ Centenário, certamente, exercerá um grande apelo não apenas sobre a população como, também sobre os diversos veículos de divulgação. (...) está sendo construída nas instalações da Base Naval de Aratu, em Salvador, Bahia, sob a coordenação do Clube Naval e contando com a colaboração de Patrocinadores que estão apoiando o Projeto do Instituto Memorabília. A construção atenderá a critérios específicos de fidelidade histórica, envolvendo todo um trabalho de pesquisa das informações hoje disponíveis sobre as naus construídas no final do século $\mathrm{XV}$, sem se descuidar da sua adequação aos requisitos modernos de segurança e conforto. $O$ prazo previsto para a construção é de aproximadamente dezoito meses.

O Governo vai bancar o término da construção da Nau Capitânia, embarcação que será destaque na festa dos 500 anos do Brasil. O ministro Rafael Greca dia 26 de agosto, no Clube Naval, no Rio, libera R\$ 2,5 milhões para conclusão da embarcação. A Nau será uma espécie de museu histórico flutuante que, depois depercorrer toda a costa brasileira, ficará ancorada em Porto Seguro como memória do descobrimento do Brasil A construção da embarcação foi iniciada em agosto de 1998 pelo Instituto Memorabília em parceria com o Clube Naval, responsável pelo gerenciamento da obra. $O$ barco foi projetado pelo engenheiro naval Rogério D'Oliveira, Almirante da Marinha Portuguesa, e desenvolvido pelo arquiteto

\footnotetext{
${ }^{46}$ Site do Tribunal de Contas da União - Número Interno do Documento: DC-0954-44/00-P https://contas.tcu.gov.br/juris/ - acesso em 31 de Agosto de 2013.
} 
Henry Schlomog Monsey, tendo sido fabricada na Base Naval de Aratu Construção da réplica histórica da Nau Capitânia, comandada por Pedro Álvares Cabral quando descobriu o Brasil. Base historiográfica mantida, embora tenham sido previstas adaptações em respeito às normas atuais de segurança da navegação e da salva-guarda da vida humana no mar $(\ldots)^{47}$.

O convênio para a construção da nau foi assinado entre o governo e o Instituto Memorabília, cujo presidente era Sérgio Aguiar, em 30 de agosto de 1999. Em nome do Ministério do Esporte e Turismo, o documento foi assinado pelo então ministro, Rafael Greca. A nau ficou pronta em Abril de 2000. Apesar do convênio dizer que aplicou $\mathrm{R} \$ 2,5$ milhões no projeto, houve suspeita de má aplicação destes recursos.

Sobre o incidente, a Revista Veja de 03 de Maio de 2000, em matéria intitulada De nau a pior, diz:

\begin{abstract}
A festa dos 500 anos acabou em samba-enredo. Para comemorar a chegada de Pedro Álvares Cabral a Porto Seguro, programou-se a aparição de um navio-abre-alas, uma réplica da nau Capitânia, aquela que conduziu a frota portuguesa na travessia do Atlântico. Quando zarpou para o local da festa, o barco ficou cheio de água e interrompeu a viagem antes que afundasse com toda a tripulação ${ }^{48}$.
\end{abstract}

Depois de resolvido o problema, a nau veio para o Rio, onde ficou ancorada na marina da Glória (zona sul) e aberta à visitação durante um pequeno período.

Em seguida, ela permaneceu sete anos em frente ao Departamento Náutico Charitas do Clube Naval. Já em 20 de março de 2007, por determinação judicial, foi oficialmente entregue à União Federal, representada pela Secretaria Especial de Aquicultura e Pesca, tendo sido rebocada para a Base Naval do Rio de Janeiro, onde permaneceu atracada até 2009. A partir de setembro de 2009, ficou em exposição no Espaço Cultural da Marinha, no centro do Rio de Janeiro, identificada como "Nau dos Descobrimentos". Olhando para ela nos vem à memória mais o fracasso das comemorações dos 500 anos do Brasil do que as heróicas travessias oceânicas.

\footnotetext{
${ }^{47}$ Idem.

${ }^{48}$ Site da Revista Veja http://veja.abril.com.br/030500/p_044.html - acesso em 24 de Agosto de 2013.
} 


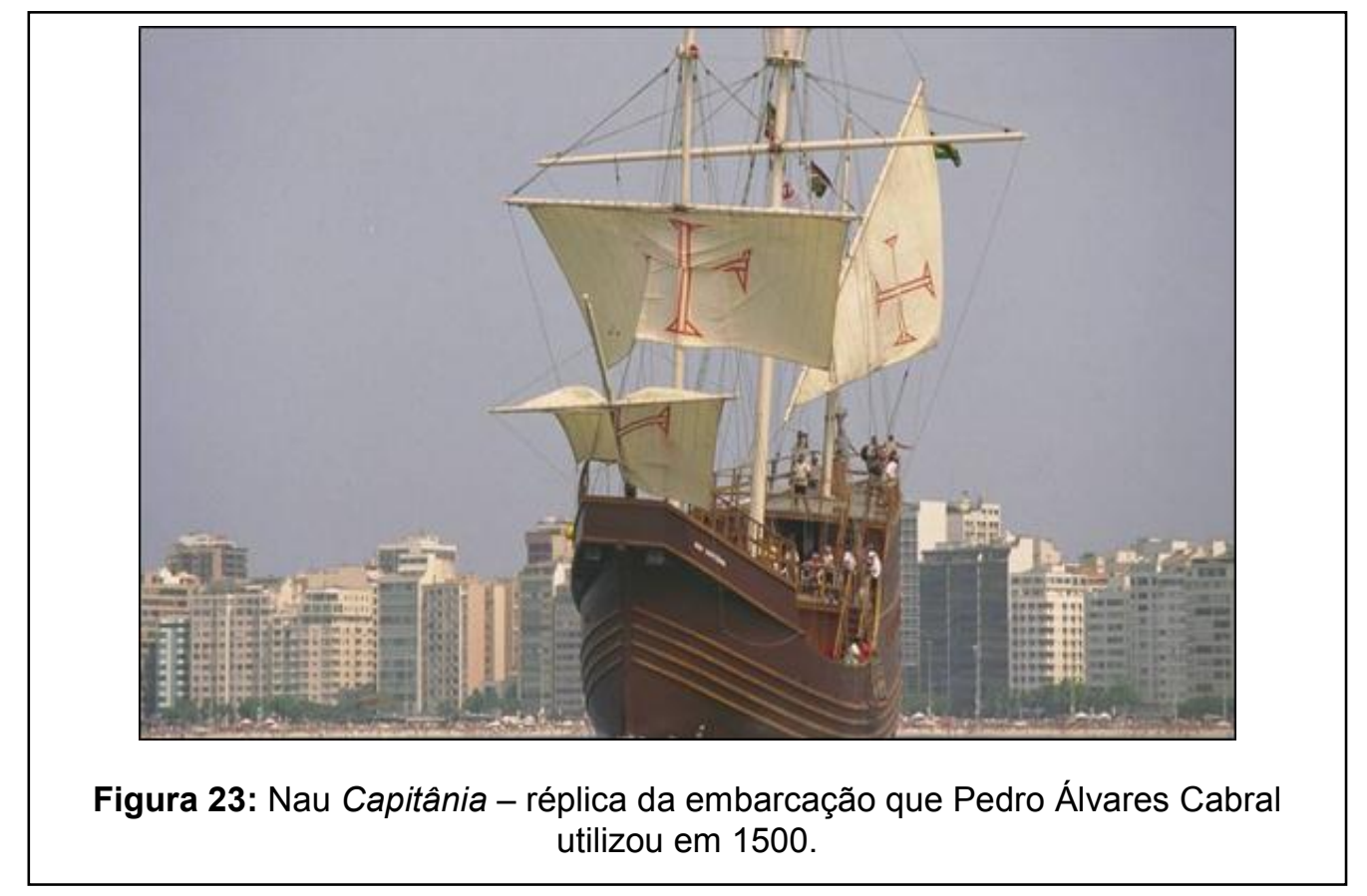

Depois de resolvido o problema, a nau veio para o Rio, onde ficou ancorada na marina da Glória (zona sul) e aberta à visitação durante um pequeno período.

Em seguida, ela permaneceu sete anos em frente ao Departamento Náutico Charitas do Clube Naval. Já em 20 de março de 2007, por determinação judicial, foi oficialmente entregue à União Federal, representada pela Secretaria Especial de Aquicultura e Pesca, tendo sido rebocada para a Base Naval do Rio de Janeiro, onde permaneceu atracada até 2009. A partir de setembro de 2009, ficou em exposição no Espaço Cultural da Marinha, no centro do Rio de Janeiro, identificada como "Nau dos Descobrimentos". Olhando para ela nos vem à memória mais o fracasso das comemorações dos 500 anos do Brasil do que as heróicas travessias oceânicas.

Uma dúvida paira diante de tudo isso: como os portugueses, há mais de quinhentos anos e sem a tecnologia dos tempos atuais, construíam caravelas capazes de percorrer mares e oceanos, enfrentando calmarias e tempestades marítimas. Enquanto a réplica, construída no ano 2000 e que custou mais de 2,5 milhões de reais aos cofres públicos, sequer conseguiu levantar âncora para chegar a tempo das comemorações.

Algo que envergonhou toda a nação, sem dúvida alguma, e que piora ainda mais quando pensamos que tantos outros projetos de alta qualidade artística e criatividade permanecem engavetados por falta de apoio oficial. 

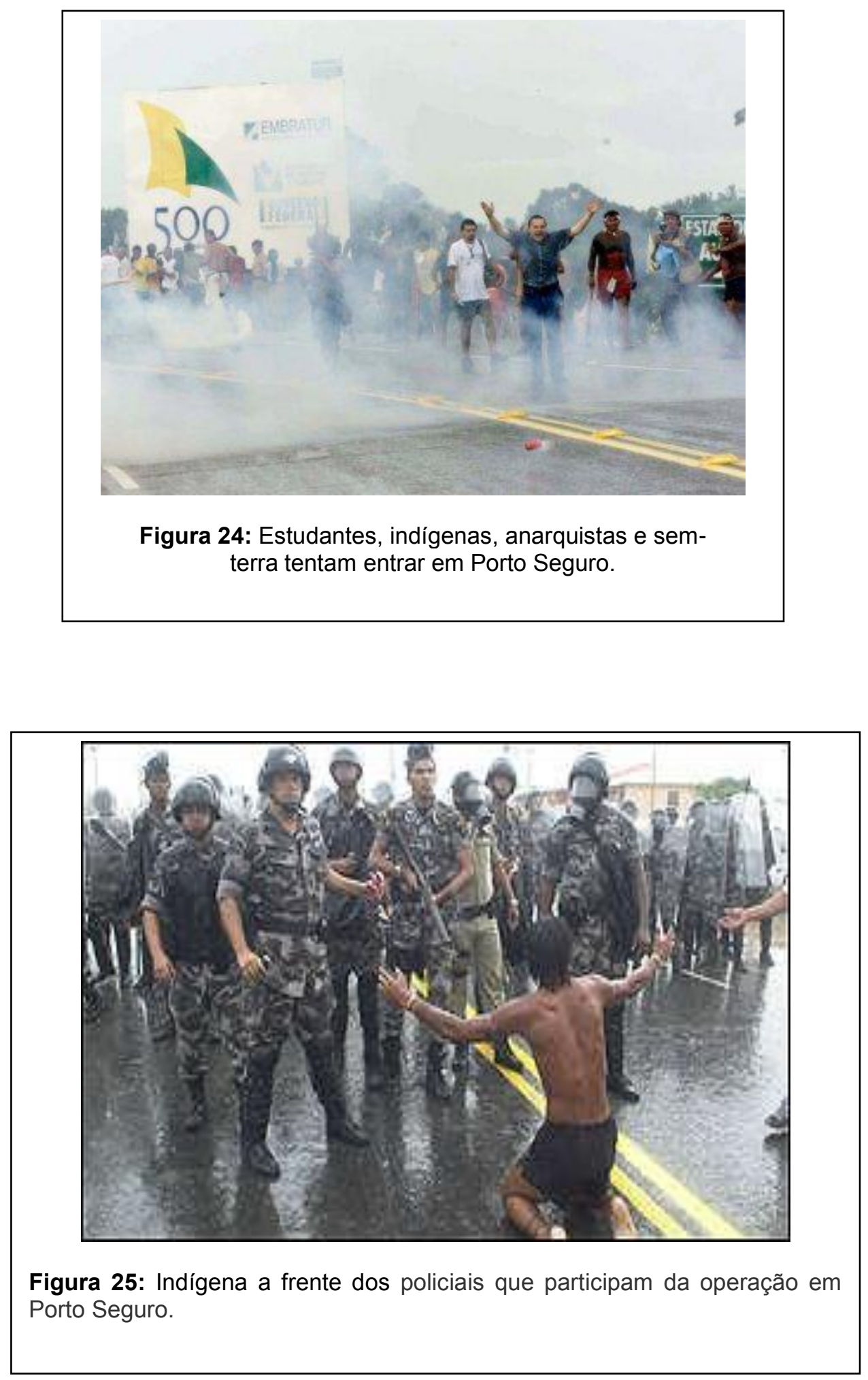

Além da nau não ter zarpado, o evento oficial foi marcado por protestos. Diante desta situação, jornais de outros países estamparam negativamente os acontecimentos de Porto Seguro, como o espanhol El País: "Amargo quinto centenário no Brasil", o jornal francês Le Monde: "Brasil comemora 500 anos 
reprimindo índios" e o britânico The Observer: "Índios lideram protestos enquanto o Brasil festeja".

Mesmo marcado pela violência, as festas programadas em Porto Seguro foram realizadas, com a presença de convidados europeus e representantes da elite brasileira, dentre os quais o presidente do Brasil, Fernando Henrique Cardoso ao lado de seu colega português Jorge Sampaio. Para impedir outras manifestações, os índios pataxós, da tribo Pataxó (que estão na região desde antes da chegada dos portugueses), foram impedidos de percorrerem pelas ruas e vielas da cidade. Ou seja, o direito de ir e vir destes que deveriam ser mais donos daquela região que os brancos foi tolhido mais uma vez, em nome de uma festa comemorativa excludente que demonstra que o conflito entre ocupantes e ocupados não foi solucionado.

\begin{abstract}
Não satisfeito com o uniforme de praxe [dos indígenas, que usavam seus trajes rituais]: penachos, colares, bermudas e sandálias havaianas, o Ministério do Esporte e Turismo mandou confeccionar sungas e maiôs cor da pele, para que os moradores originais do Brasil escondessem suas vergonhas caso resolvessem aparecer na festa com os balangandãs de fora. Havia uns 3000 sem-terra nas imediações, ameaçando melar a comemoração oficial com um protesto. Quando os indígenas e os sem-terra decidiram aproximarse da ala das autoridades, entrou em ação a ala da Polícia Militar baiana, integrada por 5000 rapazes bem nutridos. O resultado foi o que se viu na TV. Os índios, que apanham dos brancos desde os tempos de Cabral, apanharam novamente, desta vez em companhia dos sem-terra ${ }^{49}$.
\end{abstract}

Por conta da atuação extremamente repressiva do Estado do Bahia, governado por César Borges, que era do antigo PFL, contra dos manifestantes, durante as comemorações dos 500 anos, a Justiça Federal acolheu o pedido de uma ação civil pública do Ministério Público Federal na Bahia, no ano de 2012, e condenou o Estado da Bahia a pagar indenização por proibir uma manifestação pacífica. Para o Judiciário os manifestantes queriam apenas conferir pluralidade ao evento, e não frustrar a comemoração realizada pelo governo. Diante disso, era dever do Estado adotar providências para que os manifestantes exercitassem o direito de dialogarem integralmente, em vez de impedir os índios de se reunirem. "Não se justifica a atuação repressiva da Polícia Militar em relação aos manifestantes, não sendo possível reconhecer que os agentes estatais agiram no estrito cumprimento do dever legal", afirma a sentença.

\footnotetext{
${ }^{49}$ Site da Revista Veja http://veja.abril.com.br/030500/p_044.html_- acesso em 24 de Agosto de 2013.
} 
Segundo publicação do site da Procuradoria da República da Bahia, de 31 de Agosto de 2012:

O Estado da Bahia terá de pagar dez milhões de reais de indenização por dano moral coletivo por impedir o direito constitucional de reunião e de liberdade de expressão de índios, negros e cidadãos comuns durante $0 \quad 5^{\circ}$ Centenário do Descobrimento do Brasil, em 22 de abril de 2000, em Porto Seguro/BA. Trata-se de uma sentença da Justiça Federal em Eunápolis/BA, de 9 de agosto, e que acolhe pedido de uma ação civil pública proposta pelo Ministério Público Federal na Bahia (MPF/BA).

A indenização deve ser paga com juros e correção monetária e revertida ao Fundo de Defesa dos Direitos Difusos, conforme prevê o art. 13 da Lei no 7347/85. Na ação, o MPF argumentou que a Polícia Militar baiana reprimiu uma manifestação pacífica de diversos índios, integrantes do movimento negro, estudantes e outros cidadãos, que seguiam da enseada de Coroa Vermelha, há cerca de $20 \mathrm{Km}$ de Porto Seguro, para o Centro Histórico da cidade a fim de expor a visão do grupo sobre o significado dos 500 anos de descobrimento do país. Apesar de não portarem armas e carregarem apenas faixas, bandeiras e panfletos, bem antes do local dos festejos oficiais os manifestantes foram surpreendidos por uma barreira policial que impediu o prosseguimento da marcha com uso de bombas de gás lacrimogênio e balas de borracha ${ }^{50}$.

50 Site da Procuradoria da República da Bahia: http://www.prba.mpf.mp.br/mpf-noticias/direitos-docidadao/estado-da-bahia-tera-de-pagar-r-10-mi-por-danos - acesso em 24 de Agosto de 2013. 


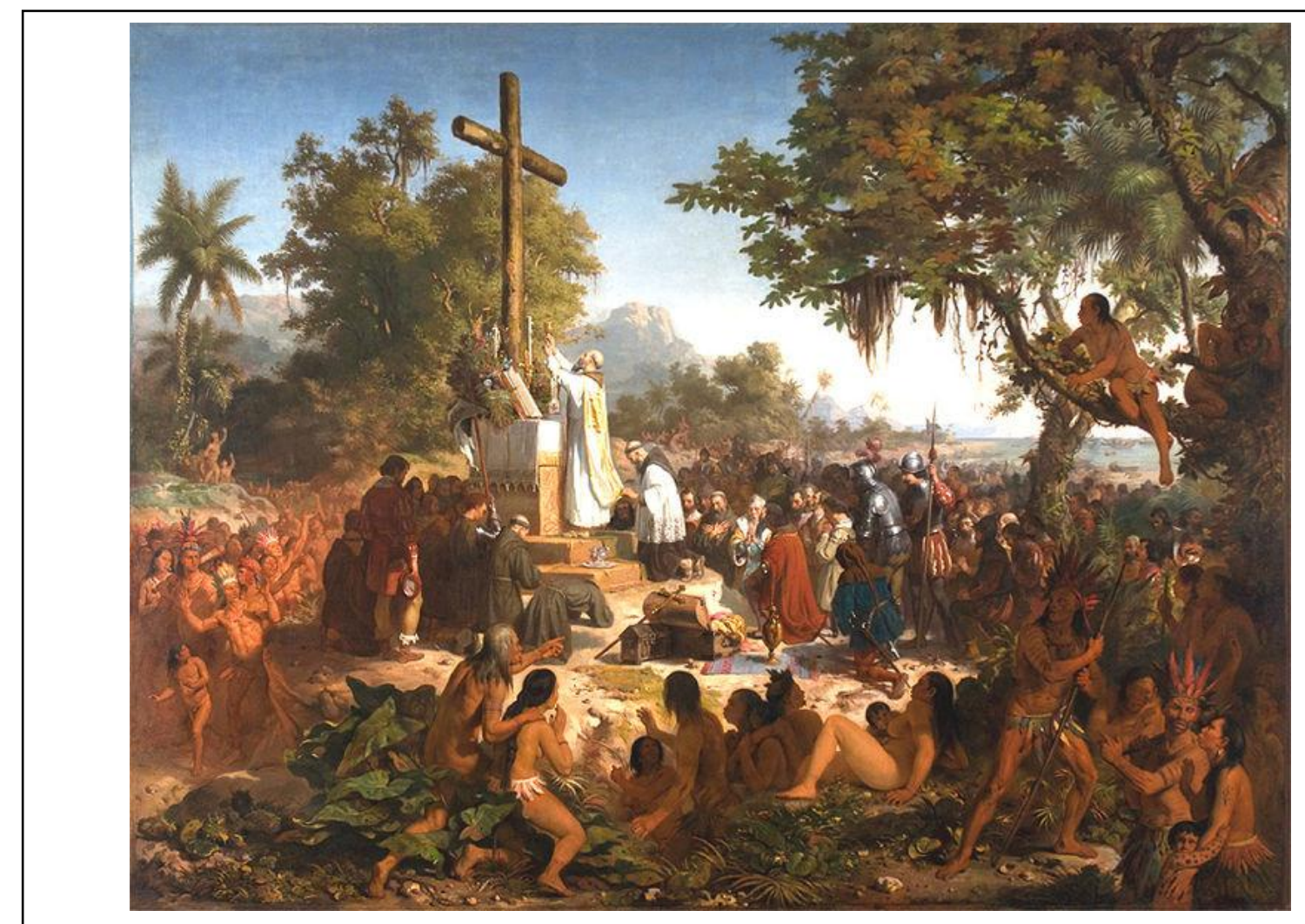

Figura 26: A Primeira Missa no Brasil - de Victor Meirelles (1861).

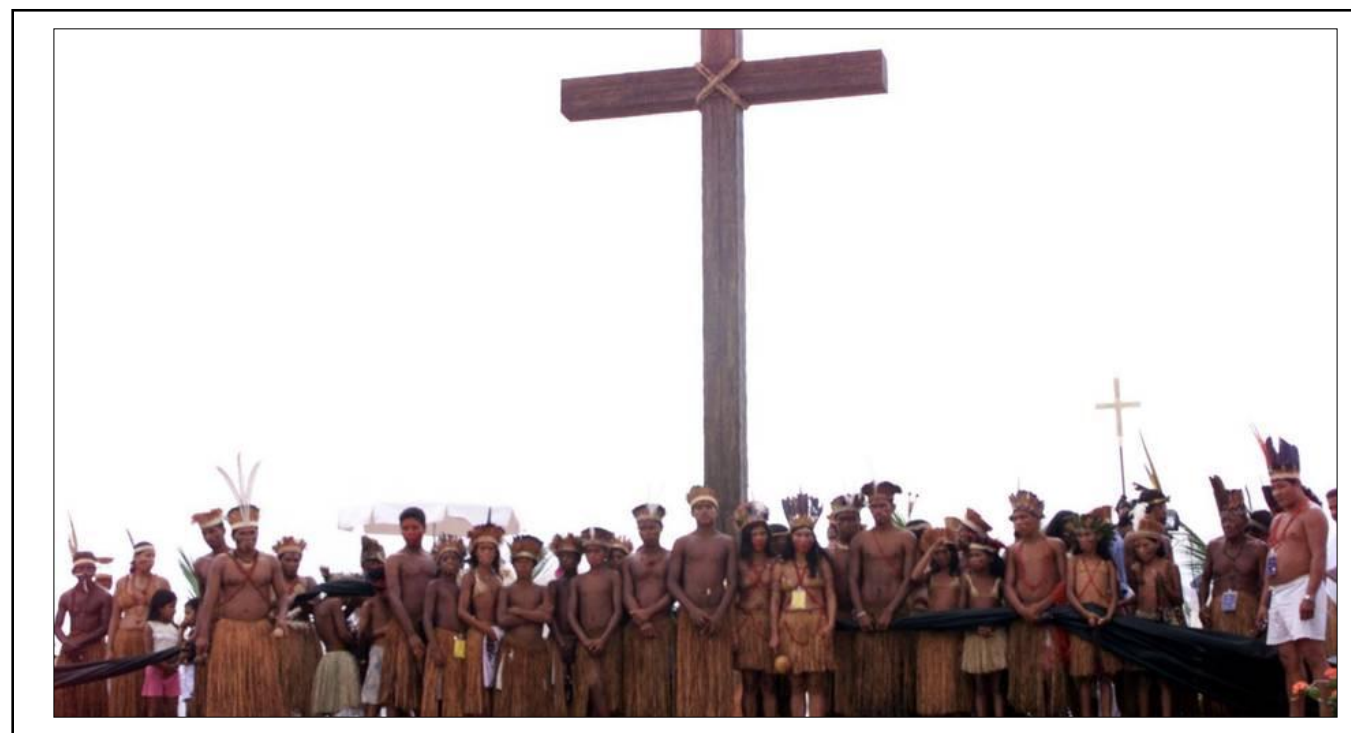

Figura 27: Índios participam da missa em comemoração aos 500 anos Coroa Vermelha (Bahia). 
No mesmo período das comemorações, deu-se também a assinatura do Tratado de Amizade, Cooperação e Consulta entre a República Federativa do Brasil e a República Portuguesa, assinado em 22 de Abril de 2000 (Porto Seguro - BA), que veio para substituir o Estatuto da Igualdade Brasil-Portugal, de 1971, que surgiu com a assinatura da Convenção sobre Igualdade de Direitos e Deveres entre Brasileiros e Portugueses. O Tratado assinado em 2000 foi promulgado pelo Decreto 3.927, de 19 de setembro de 2001.

\subsection{RESULTADO DA PESQUISA À LEI DE ACESSO À INFORMAÇÃO}

Abaixo, a título de amostra podemos ver o que foi gasto nessa comemoração de Porto Seguro, segundo dados facilitados pela Lei de Acesso à Informação:

\section{Dados do pedido}

Protocolo: $72550.000281 / 2013-16$

Solicitante: Thais Thomaz Bovo

Descrição da solicitação: Gostaria de saber informações sobre a comemoração que houve em Porto Seguro, no ano de 2000, em comemoração aos 500 anos do Brasil. Preciso saber quem foram os idealizadores, apoiadores e patrocinadores? Tbm quero saber qual o valor gasto para a comemoração? Especialmente para a construção da nau, que estava lá em 22/04/2000? Att.

A resposta foi enviada por e-mail, em 28 de Janeiro de 2013, da seguinte maneira:

\section{Prezada Senhora Thais Bovo,}

Boa tarde!

Conforme nossa conversa por telefone, juntando as informações enviadas pela Senhora, entendemos que o convênio número 372770, com o objeto "DESENVOLVIMENTO DE ACOES INTEGRADAS, VISANDO A DESINTRUCAO E A REVITALIZACAO DO ARRAIAL DA COROA VERMELHA, LOCAL DAS COMEMORACOES DOS 5OOANOS DO DESCOBRIMENTO DO BRASIL." é o que pode atendê-la em sua solicitação. 
Existem informações que podem ser obtidas no Portal da Transparência. Para acessá-las, siga os seguintes passos:

1) Entre no site http://www.portaltransparencia.gov.br/convenios/;

2) Escolha "Órgão Concedente";

3) Clique em "Ministério do Turismo";

4) Escolha o estado - no caso: Bahia

5) No campo esquerdo inferior da tela, no campo "Pesquisa", insira o nome "Porto Seguro".

Continuando a consulta, mais dados ainda podem ser obtidos da seguinte forma:

1) Acesse http://api.convenios.gov.br/siconv/dados/convenio/705270.html;

2) Para consultar um convênio, só trocar o número SIAFI http://api.convenios.gov.br/siconv/dados/convenio/705270.html;

3) Esse número a Senhora consegue realizando a consulta no Portal da Transparência (primeira orientação). É o número que aparece à esquerda da tela, em azul - 372770 ;

4) Troque - o a cada consulta para obter as informações.

Qualquer dúvida estamos à disposição!

A pesquisa foi realizada no site do Portal da Transparência, conforme orientação da Lei de Acesso à Informação, chegando-se ao seguinte resultado ${ }^{51}$ :

UF: $\quad B A$

Município: PORTO SEGURO

Detalhes do Convênio

Número do Convênio

SIAFI:

372770

Situação:

Concluído

No Original:

002/99

Objeto do Convênio:

DESENVOLVIMENTO DE ACOES INTEGRADAS, VISANDO A DESINTRUCAO E A REVITALIZACAO

COMEMORACOES DOS 500 ANOS DO

DESCOBRIMENTO DO BRASIL.

Orgão Superior: MINISTERIO DO TURISMO

Concedente:

COORDENACAO-GERAL DE CONVENIOS - CGCV

Convenente: COMPANHIA DE DESENVOLVIMENTO URBANO DO ESTADO DA BAHIA

\footnotetext{
${ }^{51}$ A resposta foi extraída a partir do site:

http://www.portaltransparencia.gov.br/convenios/DetalhaConvenio.asp?CodConvenio=372770\&Tip oConsulta=1 (acesso em 02 de Fevereiro de 2013).
} 


\begin{tabular}{|ll|}
\hline Valor Convênio: & $\mathbf{8 . 8 8 7 . 8 2 4 , 0 0}$ \\
Valor Liberado: & $\mathbf{8 . 8 8 7 . 8 2 4 , 0 0}$ \\
\hline Publicação: & $\mathbf{2 0 / 0 8 / 1 9 9 9}$ \\
Início da Vigência: & $\mathbf{3 0 / 0 7 / 1 9 9 9}$ \\
Fim da Vigência: & $\mathbf{3 0 / 0 6 / 2 0 0 0}$ \\
Valor Contrapartida: & $\mathbf{3 . 3 9 3 . 9 1 2 , 0 0}$ \\
Data Última Liberação: & $\mathbf{2 6 / 0 4 / 2 0 0 0}$ \\
Valor Última Liberação: & $\mathbf{2 . 7 8 7 . 8 2 4 , 0 0}$ \\
\hline
\end{tabular}

Pode-se com isso concluir que o valor gasto apenas nas obras de revitalização do Arraial da Coroa Vermelha foi de $\mathrm{R} \$ 8.887 .824,00$. Um valor bastante elevado, diante do resultado pouco satisfatório do evento ocorrido lá, em comemoração aos 500 anos do Brasil, como será visto no transcorrer da pesquisa.

\subsection{MOSTRA DO REDESCOBRIMENTO - BRASIL +500}

A Mostra do Redescobrimento - Brasil + 500 anos, inaugurada oficialmente em 23 de abril de 2000, buscava mostrar o percurso da arte brasileira desde a préhistórica até a arte contemporânea, atraindo cerca de dois milhões de visitantes. Como proposta, foram criados 13 módulos temáticos e para cada módulo um catálogo com o conteúdo de cada núcleo, dentre os quais:

- "Arqueologia paleolítica";

- "Artes indígenas";

- "Arte: evolução ou revolução?";

- "A primeira descoberta da América", que incluía a Carta de Pero Vaz de Caminha;

- "Arte popular", incluindo folclore e arte ingênua;

- "Negro de corpo e alma"- manifestações culturais de e sobre os negros;

- "Arte do século XIX";

- "Imagens do barroco", dos séculos XVI e XVII;

- "Arte afro-brasileira";

- "Imagens do inconsciente"- a arte produzida por pacientes do Museu do Inconsciente, criado por Nise da Silveira;

- "Arte do século XX" - "Arte moderna" e "Arte contemporânea" brasileiras; 
- "O olhar distante"- a arte europeia em visões sobre o Brasil;

- "Cine-caverna", com projeções em telas com sítios arqueológicos.

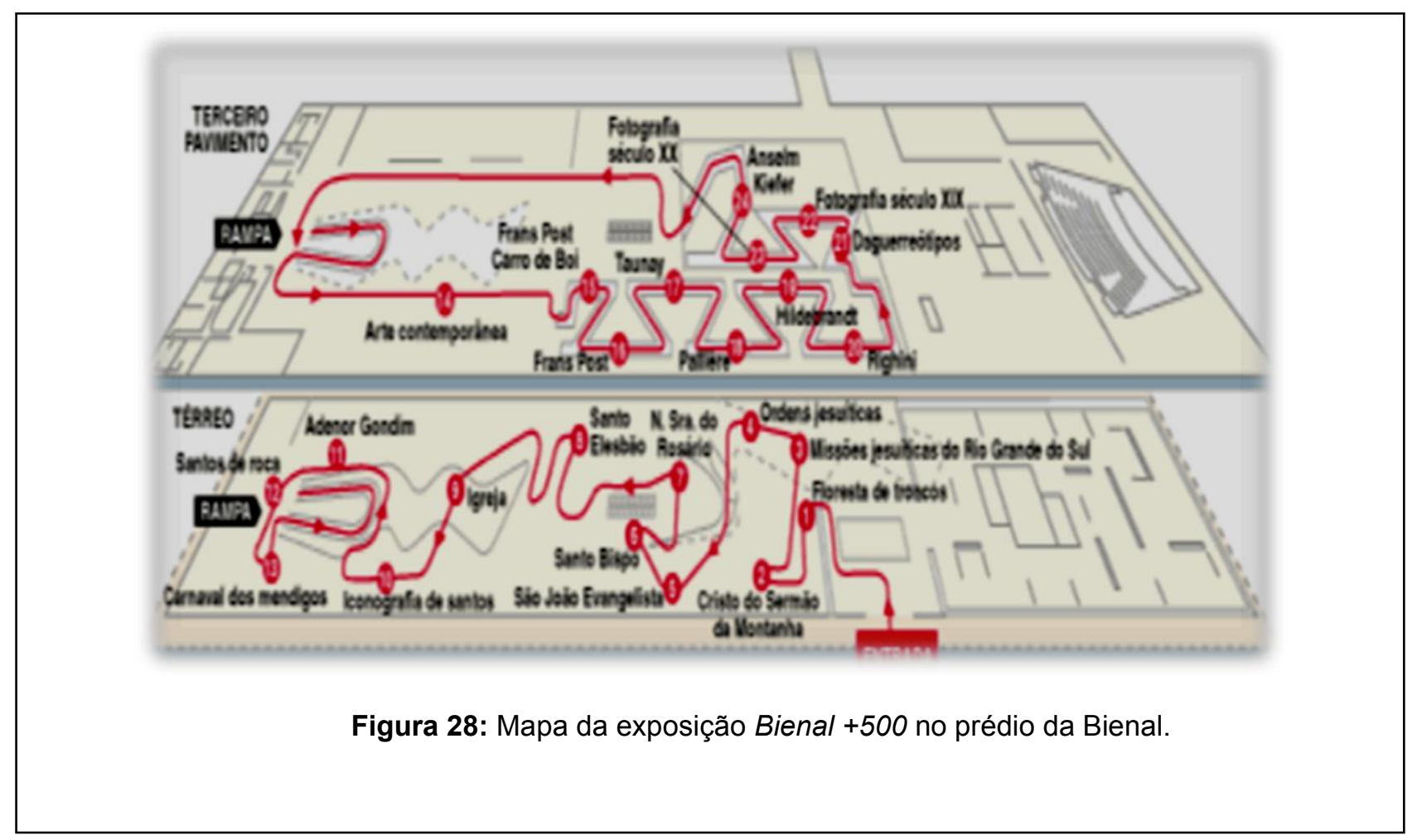

A organização da Mostra do Redescobrimento foi encaminhada da seguinte maneira: Edemar Cid Ferreira, ex-dono do Banco de Santos e presidente da Fundação Bienal em 1994 e 1996, foi responsável pela gestão administrativa, introduzindo novas políticas de financiamento e marketing. No catálogo da Mostra, ele se manifestou:

A exposição em sua totalidade apresenta-se no Parque lbirapuera, desenhado para comemorar um outro aniversário, o quarto centenário da cidade de São Paulo, em 1954. (...) No ano 2000, ocorreu a extensão desse anseio mediante a ocupação artística de três pavilhões e da marquise ao prazer do transeunte, que exerce o direito de ir e vir num passeio sombreado, ao abrigo das intempéries (...). O que ultrapassa a capacidade de ser exposto está contemplado em uma instalação virtual, meio apropriado para dar conta de manifestações artísticas de cunho territorial, como os sambaquis do litoral do país, a arte rupestre registrada em reservas naturais e as cerimônias indígenas, seus rituais e inscrições corporais. A comunicação daquilo que extravasa os limites físicos necessita de um veículo inédito capaz de propiciar um acréscimo substantivo à 


$$
\text { percepção }{ }^{52} \text {. }
$$

Vale dizer que na década de 90, vários equipamentos culturais públicos da cidade - como a Pinacoteca e o Paço das Artes, passaram por uma fase inicial de privatização, quando o Estado resolveu entregá-los a diretores que possibilitariam financiamentos, o que levou à criação de administrações independentes, o mesmo acabou acontecendo com a Bienal, cujo plano foi proposto através da Associação Brasil 500 Anos de Artes Visuais, uma coalizão que, em 2001, se rebatizou de BrasilConnects, afinando-se a uma suposta internacionalização.

Quanto ao financiamento, a partir da matéria do jornalista Celso Fioravante intitulado "Mostra do Redescobrimento gasta R $\$ 40$ milhões em SP", para o Jornal Folha de São Paulo de 19 de Abril de 2000, tem-se uma dimensão dos recursos financeiros necessários para esta mega exposição:

\begin{abstract}
Segundo a organização do evento, serão cerca de 15 mil obras divididas em 60 mil metros quadrados de área expositiva (divididos entre Pavilhão da Bienal, Pavilhão Manoel da Nóbrega e Oca, antigo Museu de Aeronáutica). O custo é de cerca de $\mathrm{R} \$ 40$ milhões, boa parte dele usado na reforma dos pavilhões e nas cenografias da mostra, como a criada por Bia Lessa para o segmento Arte Barroca, que consumiu cerca de R\$1,1 milhão. (Folha de São Paulo - 19 de Abril de 2000).
\end{abstract}

Um dos destaques da exposição foi a carta de Pero Vaz de Caminha, no módulo "A primeira descoberta da América", que apresentava também pinturas e desenhos com mais de 12 mil anos. Este módulo foi criado para trazer a discussão sobre a chegada do homem à América através da passagem pelo Estreito de Bering dos habitantes do norte da Ásia, há doze mil anos.

Sobre a carta de Pero Vaz de Caminha, documento que esteve guardado na Torre do Tombo em Lisboa e que foi cedido para a Mostra, sendo depois devolvido a Portugal.

A Carta só chegou a conhecimento do público no início do século XIX, no Rio de Janeiro, ou seja, permaneceu por mais de dois séculos desconhecida. Esse documento histórico registrou o encontro entre os navegadores portugueses e os nativos da terra, sob o olhar destes primeiros e permanece como testemunho do encontro de civilizações.

O texto original foi transcrito para o português atual pelo historiador Paulo

\footnotetext{
${ }^{52}$ A resposta foi extraída a partir do site:

http://www.portaltransparencia.gov.br/convenios/DetalhaConvenio.asp?CodConvenio=372770\&Tip oConsulta=1 (acesso em 02 de Fevereiro de 2013).
} 
Roberto Pereira. Houve também o trabalho conjunto de vinte e dois artistas contemporâneos, portugueses e brasileiros, que apresentaram interpretações sobre o significado da Carta de Pero Vaz de Caminha.

Já no módulo das Artes Indígenas, cujo curador foi José Antônio Braga Fernandes Dias, o principal era a apresentação do contexto artístico geral, bem como as diversas práticas artísticas das tribos indígenas brasileiras. Foram escolhidas máscaras, artes plumárias, armas, mostrando o valor estético de cada peça, toda riqueza a ela atribuída e também pela sua inserção no cotidiano dos ameríndios.

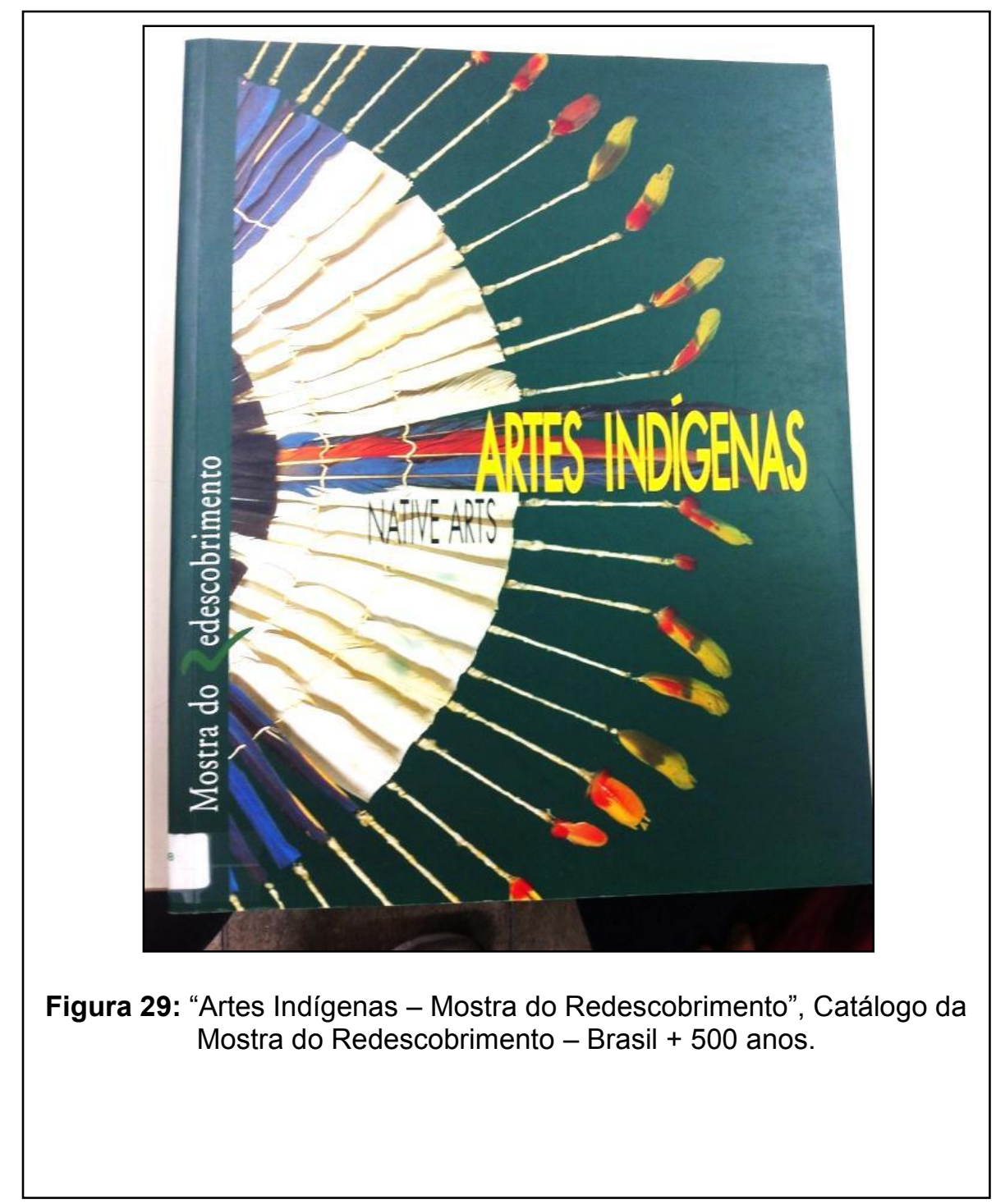


$\mathrm{Na}$ área dedicada à etnia negra, intitulado Negro de Corpo e Alma, com curadoria de Emanoel Araújo, foram expostos aproximadamente duas mil obras, incluindo telas, obras de artistas negros, tapeçarias e objetos do cotidiano.

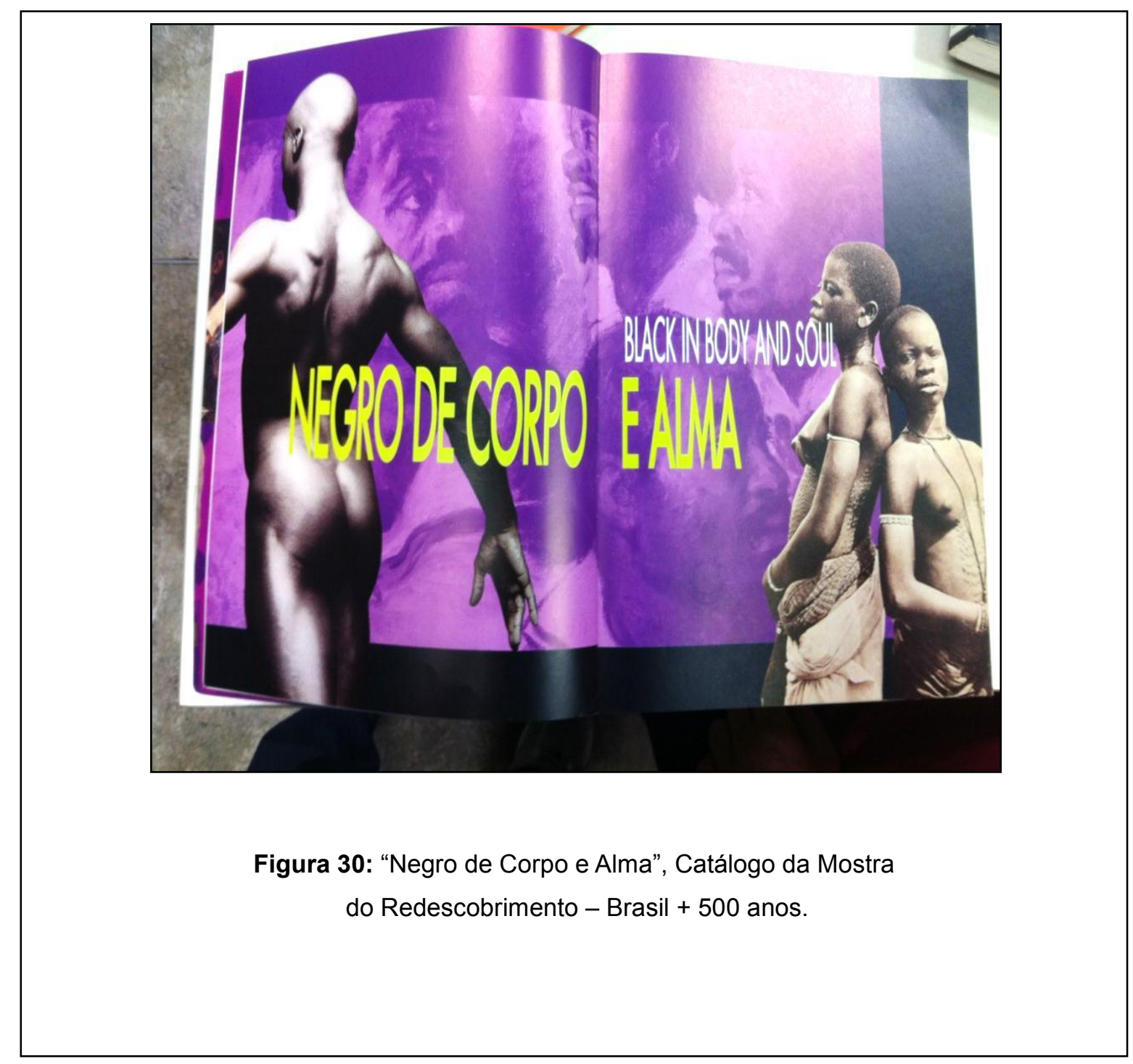


Além da Bienal de São Paulo, os módulos da mega exposição foram apresentados também em doze capitais brasileiras, separadamente, chegando a cidades de outros países, dentre os quais dezessete museus internacionais, como o do Porto, Lisboa, Londres, Cambridge, Oxford, Bordeaux, Paris, Nova York, Washington e Bilbao. A itinerância teve seu ápice na cidade de Nova York, em 19 de Outubro de 2001, quando ocupou parte do Museu Guggenheim durante a exposição "Brazil Body \& Soul" (com 260 obras), que teve um custo de produção anunciado de oito milhões de dólares pagos pela BrasilConnects, ou seja, um valor considerável para o contexto brasileiro.

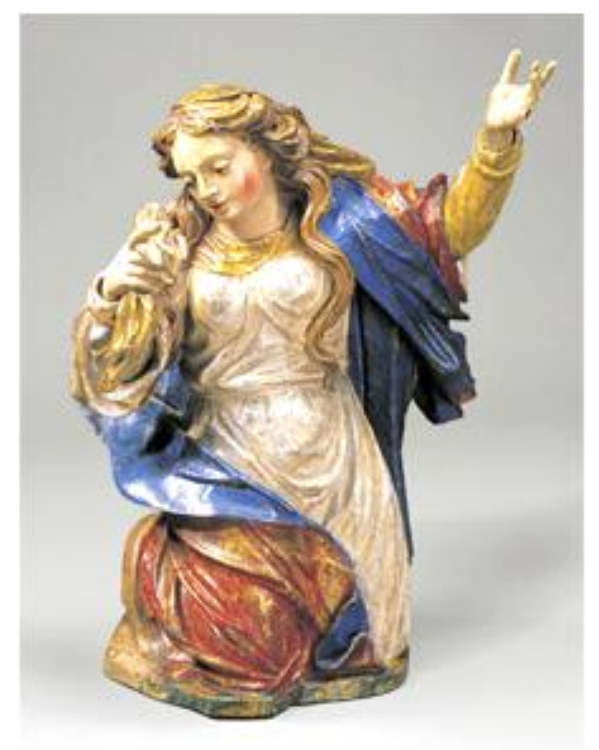

Figura 31: Maria Madalena - de Francisco Xavier de Brito - século XVIII. Uma das 260 obras que estiveram na exposição "Brazil Body \& Soul", no Museu Guggenheim, Nova York - $2001-2002$. 


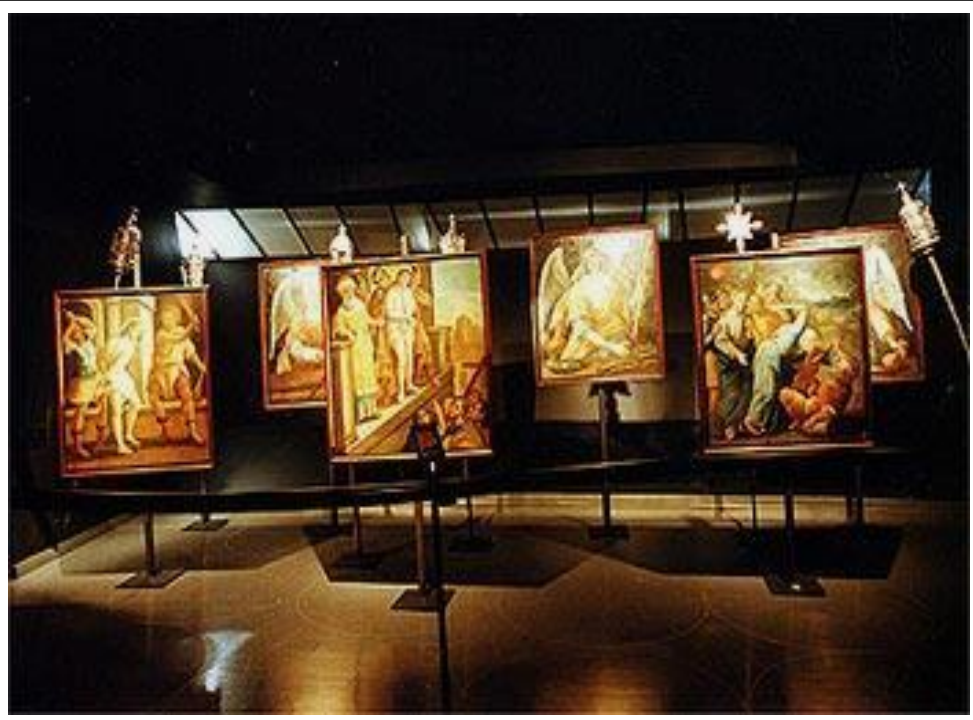

Figura 32: Peças da exposição "Brazil Body \& Soul" Museu Guggenheim de Nova York.

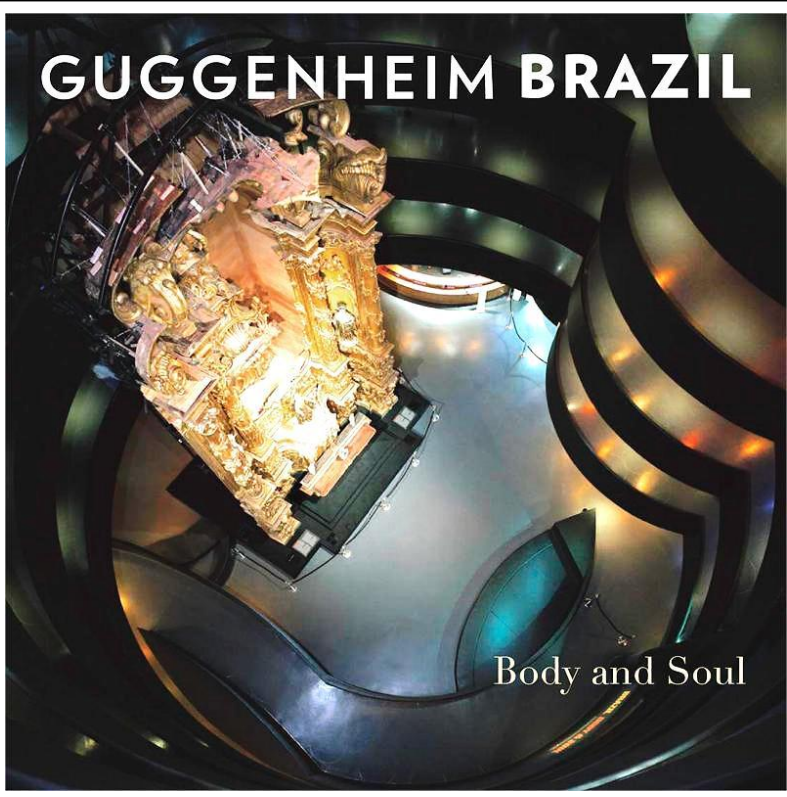

Figura 33: Capa do CD vendido pelo Museu Guggenheim na época da exposição Body and Soul, com música brasileira, como Samba e Bossa Nova. 


\subsection{ANÁLISE COMPARATIVA}

A partir desta breve análise dos eventos promovidos em decorrência das comemorações dos 500 anos de Brasil, percebe-se que em nenhum momento as relações de poder e os embates entre portugueses, negros, índios foram discutidos ou analisados. Como se tudo tivesse ocorrido de um modo pacífico e sem nenhum tipo de sofrimento. Houve o resgate por parte do Estado apenas dos mitos fundadores da nação, enaltecidos por este, que se aproveitou do momento para discutir a política contemporânea de inclusão social.

Daí se torna ainda mais valiosa a proposta crítica que o Projeto Perforum apresentava. Mas, infelizmente, diferente dos eventos oficiais (Porto Seguro) e da Mostra da Bienal (Lei Rouanet), o Projeto Perforum não contou com os recursos necessários para o seu desdobramento desejado.

$\mathrm{Na}$ ocasião cogitou-se em pedir auxílio oficial via Lei Rouanet para o Projeto Perforum, mas os entraves burocráticos tornaram inviável essa opção. A lei exigia que para obter os recursos provenientes de renúncia fiscal era necessária, primeiramente, a aprovação prévia junto ao Ministério da Cultura, para obtenção de um número de cadastro que qualificava o projeto para sair em busca de patrocínio.

Envolvia, portanto, ultrapassar duas barreiras: o aval ministerial e o convencimento do setor de marketing de uma empresa grande o bastante para bancar o projeto. Conforme Teixeira Coelho:

As produções iniciais feitas ao abrigo da lei deixaram muito a desejar devido à falta de critérios claros sobre o que poderia ser considerado artístico ou cultural, ponto nodal da questão (um primeiro momento da existência dessas leis, multiplicaram-se os livros ditos "de arte", com muita ilustração e pouco texto e feitos para servirem de brindes institucionais de fim de ano). (COELHO, 2004, p. 214).

O fato é que toda essa dificuldade inicial era muito mais fácil para uma iniciativa de perfil aos moldes da indústria cultural privada do que um projeto de experimentação da linguagem como é o caso do Projeto Perforum. Questionado se o projeto tentou algum tipo de financiamento, Artur Matuck responde:

A gente sempre tenta financiamento. Eu acho que não teve financiamento nenhum. Eu acho que teve colaboração, apoio assim, por exemplo, da Biblioteca da Faculdade de Economia e Administração da USP, da FEA, que franqueou o uso da sala de vídeo conferência. Eu acho que a gente nunca teve apoio financeiro, 
a gente nunca recebeu nada. Só teve assim, colaboração, assim, a Yara conseguiu na UDESC, a Paula Perissinoto que ofereceu o sitio, a FEA que ofereceu a sala de vídeo conferência. (MATUCK entrevista).

Nesse contexto, o Projeto Perforum acabou obtendo somente 0 apoio institucional da USP e da UDESC, onde Artur Matuck e Yara Guasque trabalhavam como professores. Isso limitou bastante o alcance do projeto, além de demonstrar a deficiência dos mecanismos de apoio à cultura da época. 
5.

PROJETO PERFORUM - DESTERRO:

ENSAIOS DE TELEPRESENÇA

O Perforum adotou a fala desse "outro" tornado exótico e distanciado do modelo eurocêntrico. Entretanto o projeto assumiu ingenuamente a estratégia colonialista dentre tantos, que mantém o nativo como exótico, o que nos obliterou na época uma autoreflexão. Do ponto de vista da desenvoltura de uma linguagem tecnológica, o projeto só manipulava a estrutura de videoconferência previamente arquitetada, repetindo as tarefas arquitetadas e padronizadas em culturas como as dos centros programadores ${ }^{53}$.

${ }^{53}$ Trecho do texto de Yara Guasque, no qual ela fala sobre o conceito de Telafagia (s/d), disponível em http://webceart.udesc.br/perforum/. Acesso em 19 de Setembro de 2013. 
Com as limitações de financiamento e recursos tecnológicos, o Projeto Perforum acaba por se concentrar nas teleconferências estabelecidas entre o núcleo da USP em São Paulo e o núcleo de Florianópolis. A partir daí foram programadas uma série de eventos que funcionavam como verdadeiras oficinas de experimentação e telepresença.

Segundo Yara Guasque (2005, p. 23), "a telepresença depende de um suporte tecnológico que possibilite, em tempo real, a comunicação dialógica e a interação em seus diferentes níveis".

Eduardo Kac por sua vez conceitua a telepresença como a interação por meio das telecomunicações que possibilita um retorno audiovisual, com o auxílio da robótica e da telerrobótica. Para ele:

A arte da telepresença é uma nova área de criação artística que se baseia no deslocamento dos processos cognitivos e sensoriais do participante para o corpo de um telerrobô, que se encontra num espaço geograficamente remoto. (KAC, 1997).

E continua:

a telepresença transporta um indivíduo de um espaço físico para outro, frequentemente via links de telecomunicação. As telecomunicações e a robótica podem reunir a transmissão e a recepção de sinais de controle de movimentos com um feedback audiovisual, háptico e de força. A telepresença virtualiza o que na verdade somente tem existência física. (KAC, 1997).

Pode-se dizer que tal qual o lápis e o papel, ou o pincel, a tinta e a tela, as redes - especialmente a web - também servem como extensões de nossos corpos e mentes, criando estruturas que exteriorizam funções cerebrais, levando os indivíduos que participam da telepresença a atuações distantes, nunca antes previstas na História. Neste âmbito, o Projeto Perforum pôde estender suas reflexões estéticas e teóricas com o uso da tecnologia, propondo a participação política de diversas pessoas, reunidas presencial ou virtualmente, a fim de interagir a distância, num encontro com o diferente para a construção de um diálogo.

Basicamente o Projeto Perforum, elaborado e coordenado por Artur Matuck, baseou-se no diálogo entre artistas, teóricos, historiadores e indivíduos de culturas que integraram o processo de colonização do Brasil.

Para Artur Matuck, esta participação nas comemorações do Brasil 500 anos visaram à redescoberta do Brasil de outra forma, pois buscou proporcionar uma 
interação dialógica entre cafuzos, europeus, africanos e americanos. O projeto deveria fomentar a participação dos excluídos do ciberespaço.

Já para Yara Guasque, o Perforum foi um:

(...) projeto de net art desenvolvido como linguagem intermídia por dois grupos, Desterro e São Paulo. As teleperformances do Perforum são um acervo rico de scripts colaborativos de performers remotos atuando a distância, explorando novas narrativas e tendo como fonte as artes cênicas, a música e as artes visuais. Antes que os scripts fossem realizados como live action através das salas multiusuário, comunicação ponto a ponto, eles eram negociados nas listas de discussão. O projeto planejou muitas outras formas de participação e de interação a distância, performances, fórum online e workshops colaborativos, e eventos para um público presencial e telepresencial ${ }^{54}$.

O resultado deste projeto, realizado entre os anos 1999 e 2000, foi uma série de eventos interativos que incluiu programação de intercâmbios multiculturais, videoconferências, videoinstalações, acionadas à distância, além de eventos públicos de teleobservações. Contou com a participação de artistas, escritores, teóricos e humanistas brasileiros, indígenas, europeus, africanos e americanos.

O projeto denominou-se "um evento de telecomunicação, artes, performance e novas narrativas" e foi aceito pela Pró-Reitoria de Cultura e Extensão Universitária da Universidade de São Paulo, USP, para fazer parte das comemorações desta universidade nos 500 anos do Brasil.

Yara Guasque foi uma das participantes desde seu início. Ela conheceu Artur Matuck quando foi sua aluna na disciplina Escrituras Eletrônicas, no Programa de Pós-Graduação da Escola de Comunicação e Artes da Universidade de São Paulo, no segundo semestre de 1998.

Yara Guasque que morava em Florianópolis, sugeriu que lá seria um bom local para trabalhar em conjunto com São Paulo, pois havia uma conexão de banda larga com pontos de alta velocidade, chamada Internet 2. Propôs, então, que esses pontos fossem utilizados para performances. Nasceram as primeiras trocas entre as cidades de São Paulo e Florianópolis.

A palavra "Desterro" foi escolhida porque este era o antigo nome anterior da cidade de Florianópolis. A mudança de Desterro para Florianópolis ocorreu em 1894,

\footnotetext{
${ }^{54}$ ARAÚJO, Yara Guasque. Perforum Desterro e Perforum São Paulo: Reconsiderando a colaboração entre a periferia e os centros. Em http://webartes.dominiotemporario.com/performancecorpopolitica. Acesso em 31 de Agosto de 2013.
} 
em homenagem ao presidente da República à época, Floriano Peixoto.

O Perforum Desterro criou sessões utilizando sistemas como o multicast (comunicação ponto a ponto ou de um ponto a muitos outros), que naquele período estava sendo testado pela RMAV-FLN (Rede Metropolitana de Alta Velocidade de Florianópolis), as ligações discadas da RDSI (Rede Digital de Serviços Integrados), o streaming de vídeo em tempo real e as salas multiusuário do iVisit na internet. $\mathrm{O}$ iVisit é um software gratuito, que permite videostreaming em tempo real e possibilita, além do vídeo, a comunicação através do chat.

O script consistiu em pedir que a imagem do vídeo recebida fosse reelaborada no whiteboard (ambiente de arquivos compartilhados), que permitiu o compartilhamento remoto do desenho em tempo real, e após a reelaboração que esse fosse enviado sendo retrabalhado da mesma maneira a cada ponto de recepção.

Para Yara Guasque, em seu artigo intitulado "Perforum Desterro e Perforum São Paulo: repensando a colaboração entre a periferia e os centros" ${ }^{55}$.

O Perforum foi um projeto da rede que desenvolveu a linguagem intermídia em tempo real unindo as artes cênicas, a música e as artes visuais na atuação de dois grupos, Desterro e São Paulo. As teleperformances do Perforum constituem um acervo rico resultante das performances remotas de telepresença com scripts colaborativos. A colaboração nas teleperformances era negociada nas listas de discussão com diversos assinantes e participantes ativos. O projeto pensou formatos de interação à distância, performances e workshops colaborativos, e eventos com um público presencial e telepresencial que hoje são realidade. Também idealizou oficinas presenciais multidisciplinares de integração interacial muito antes de esta ser uma meta governamental, como a realizada em agosto de 1999 no sítio de Paula Perissinoto em Igaratá, São Paulo, organizada por Artur Matuck e coordenada por Hiparidi Top'tiro da Nação Xavante. (ARAÚJO, s/d).

Além de Yara, os membros fixos do Perforum Desterro foram Daniel Izidoro, que atuou como diretor no início do grupo, Leonardo Romão, Janaí Pereira, Cynthia Pimenta e Rodrigo Tramonte, estudantes de Artes Visuais da UDESC. Houve também outros participantes oriundos das Artes Visuais como Michael Chapman, Fernanda Magalhães, Thomas Klasen, e também das Cênicas com a presença de

${ }^{55}$ ARAÚJO, Yara Guasque Rondon. Perforum Desterro e Perforum São Paulo: Reconsiderando a colaboração entre a periferia e os centros.

Em http://webartes.dominiotemporario.com/performancecorpopolitica, acesso em 27 de Abril de 2013. 
Laurette Pasternack e o Grupo Fome (Alai Garcia Diniz e Bruno Rocha), das Letras como Fábio Brüggeman, da TV como Francisco Caprário, da História como Beatriz Mamigonian, e da música como Januíbe. Toda participação foi voluntária, pois não houve recursos para os pró-labores.

\subsection{AS TRANSMISSÕES}

As transmissões regulares aconteceram entre o Perforum Desterro na UNIVALI em Biguaçu ou na UDESC em Florianópolis, e o Perforum São Paulo através do CIEP da Faculdade de Economia, Administração e Contabilidade da USP ou da Universidade Virtual da ANHEMBI-MORUMBI, ou ainda da Estação Ciência da USP, em São Paulo.

A UNIVALI atuou com dois datafones 64, a $128 \mathrm{kbps}$ e 15 quadros por segundo com o equipamento 4000 ZN da Picturetel, duas câmeras fixas, uma documento e saída para outra móvel. As transmissões foram ainda disponibilizadas na Internet pelo Real Player. Em algumas transmissões utilizou-se ainda os softwares comerciais como o Ivisit para possibilitar participações de acesso doméstico.

\subsection{CONCEITO}

Seu conceito fundamental foi o da interação dialógica entre criadores, indivíduos, intelectuais, regiões, etnias e culturas distantes que participaram do movimento das Navegações, da Constituição Étnica e Cultural das Américas e especialmente do Brasil.

A celebração do processo histórico das Navegações ocorreria através do descobrimento do ciberespaço e da interação cultural, marcada pela telecomunicação, pela telepresença, pela arte interativa, pelos processos de autoria coletiva.

Estes indivíduos foram desafiados a refletirem sobre a interação entre 0 homem e a máquina, entre a escala individual e planetária e a iniciarem uma nova aventura e descoberta, a do ciberespaço, traçando uma outra cartografia do mundo contemporâneo. 


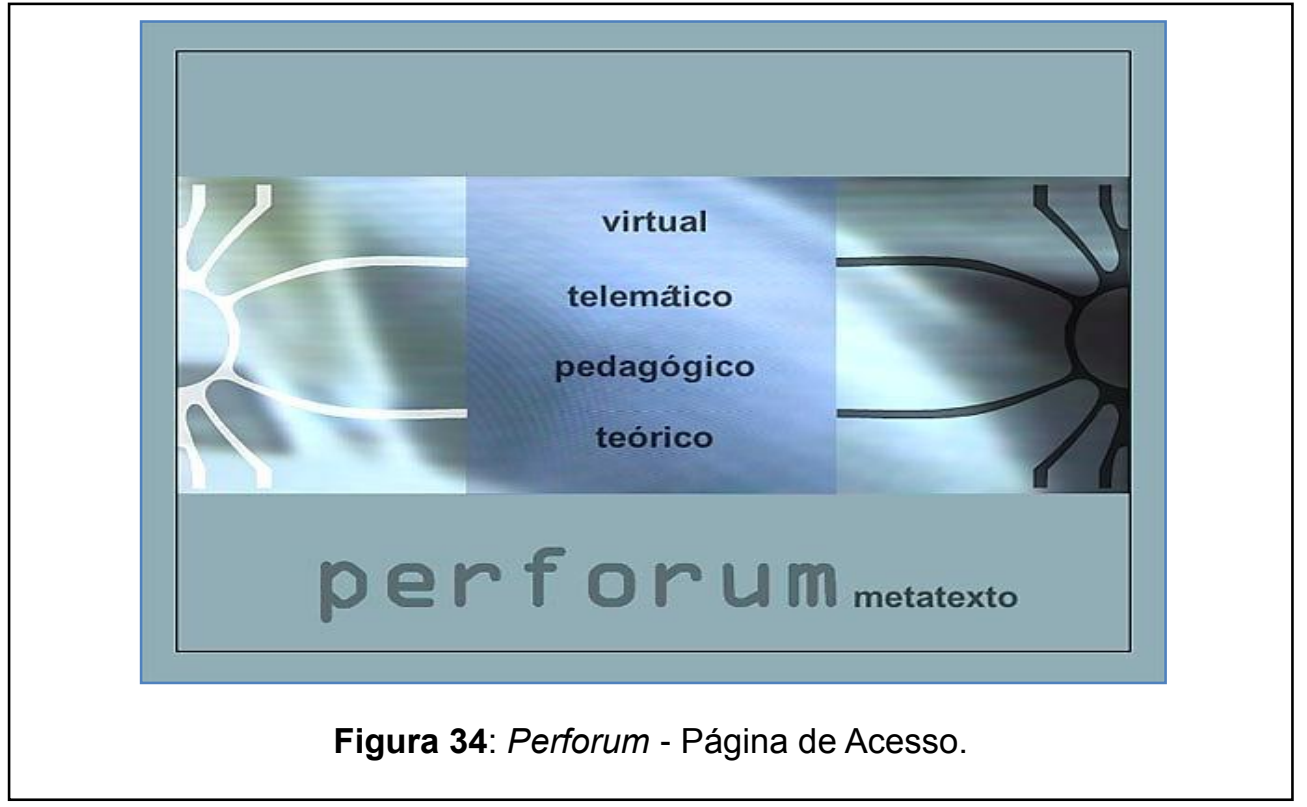

\subsection{DESCRIÇÕES DE ALGUMAS TELEPERFORMANCES}

\section{Teleperformance Lapsus Calami - 18 de Maio de 2001}

Visava à construção de uma linguagem híbrida. Durante a teleperformance, Artur Matuck leu, escreveu e reescreveu um texto, no qual ele próprio se propôs a errar (deveria ser induzido ao erro). Ele pediu a Yara Guasque, que estava em Florianópolis, que o interrompesse, perguntasse ou falasse simultaneamente e fizesse uma série de interferências sonoras para induzi-lo ao erro. Com o passar do tempo, como o Artur não errava, Yara falou que ele não estava se abrindo a interferência dela. Num determinado momento da teleperformance, Yara diz de maneira enfática: "Eu afirmo, você tem controle. É o que você mais exerce sobre você. Controle! E isso é impossível da gente poder mostrar o contrário pra você". E continua mais adiante: "só não estou conseguindo achar uma brecha dentro do seu psiquismo, pra que você faça erros".

A versão atual do evento, tal qual descrita por Artur Matuck é a seguinte:

o nome desse evento era: "Lapsus Calami", que é uma palavra que eu descobri num texto do Derrida. Que é o lapso da escrita, porque o lapso da fala é uma coisa mais conhecida, mas existiria o lapso da escrita. Então, eu li há alguns anos atrás sobre um trabalho de vídeo de um artista inglês que ele divida a tela de televisão no meio e que 
de uma lado ele lê um texto e do outro lado ele escreve um outro texto. E ele tenta ler um texto enquanto ele esta escrevendo um outro texto. Então, isso seria uma sobrecarga de informação para o cérebro e faria com que ele errasse. Ele escreveria errado ou leria errado. E daí eu tentei fazer uma obra similar, e eu me propus a ler e escrever um texto que eu tinha escrito, enquanto a Yara iria conversar comigo, interagir comigo e iria verificar se eu iria errar em algum momento. Então, a gente começou esse trabalho, eu comecei lendo e depois de duas frases a Yara me interrompe e fala assim: "eu acho que não esta dando certo. A gente devia mudar as regras, devia fazer um outro trabalho, um pouco diferente". Mas não sei se por teimosia minha, daí eu falei não. Eu vou pegar esse texto, foi o combinado que eu iria ler esse texto, e eu vou ler até o fim. Mas foi extremamente difícil eu continuar a leitura, a toda hora ela falava assim: "Não. Eu acho que não está funcionando, você não está ouvindo o que eu digo". (Entrevista - Matuck).

E Artur conclui que o "teleconflito" estava instalado, mas que esse conflito já extrapolava os temas determinados:

Eu acho que daí já não é um conflito entre o branco e o índio, entre o ocidental e o indígena, eu acho que é um conflito entre o homem e a mulher, eu acho que existe esse conflito, é um conflito entre dois artistas, entre dois criadores, entre dois escritores. Então... eu lembro que ela falou uma frase: "você quer manter o controle, o seu psiquismo não permite que você erre, que você ouça o que eu estou dizendo." (Entrevista - Matuck).

Iniciou-se, então, uma série de conflitos. O ápice foi quando o computador parou por um problema técnico e o grupo de São Paulo começou a transmitir apenas uma imagem parada. Depois disso, Yara achou que aquilo fosse proposital, o que causou uma grande perturbação e todos ficaram extremamente nervosos. Do ponto de vista perceptivo, é importante perceber que estas emoções transbordam e ultrapassam através dos meios digitais, a ponto de ocorrer uma discussão através dos equipamentos de videoconferência. Ao término da videoconferência, as imagens das pessoas remotas desapareceram aos poucos do telão e as vozes deixaram de existir. Então, uma sensação de vazio pairou e a comunicação deixou de existir. 

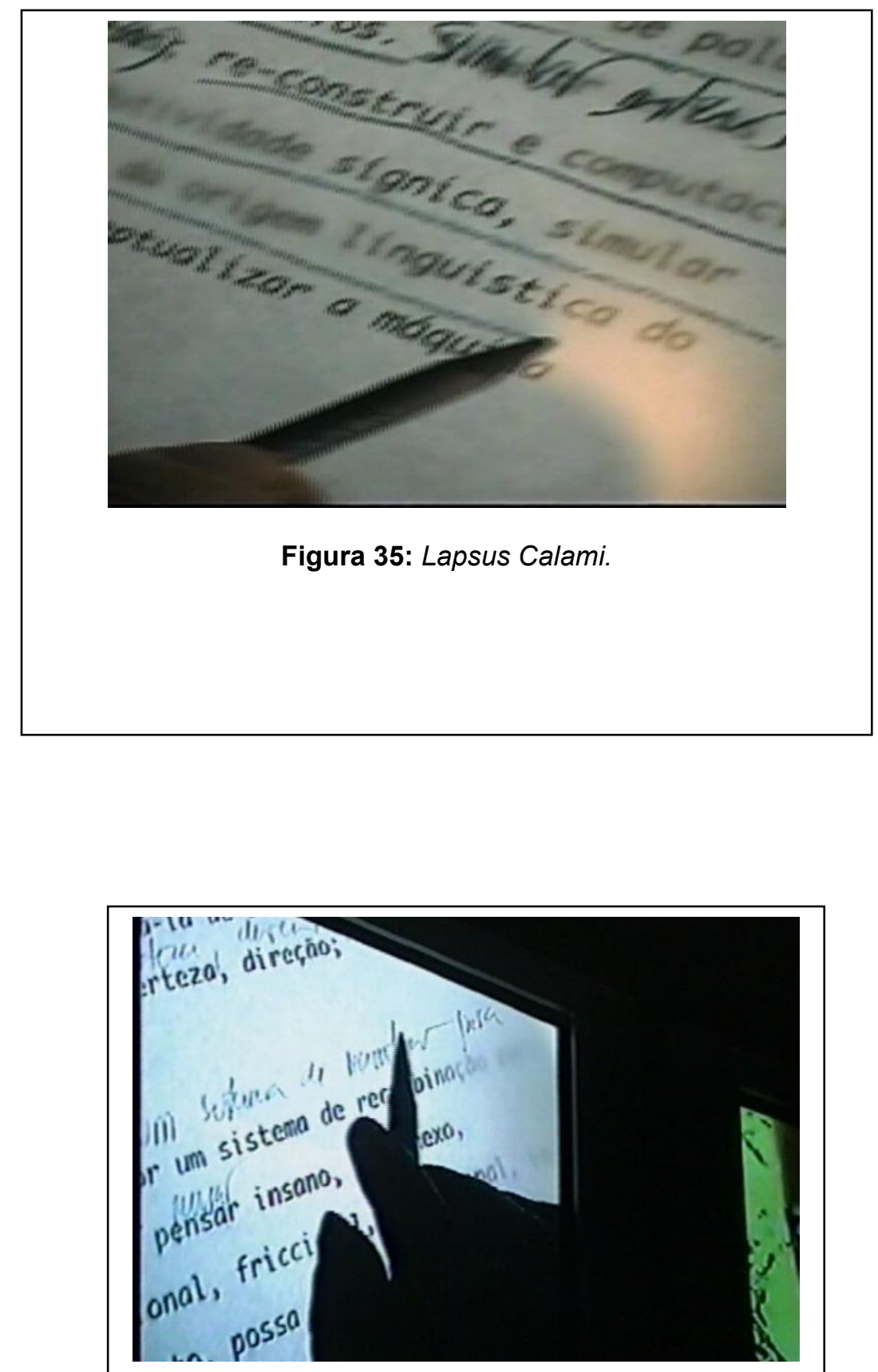

Figura 36: Lapsus Calami. 


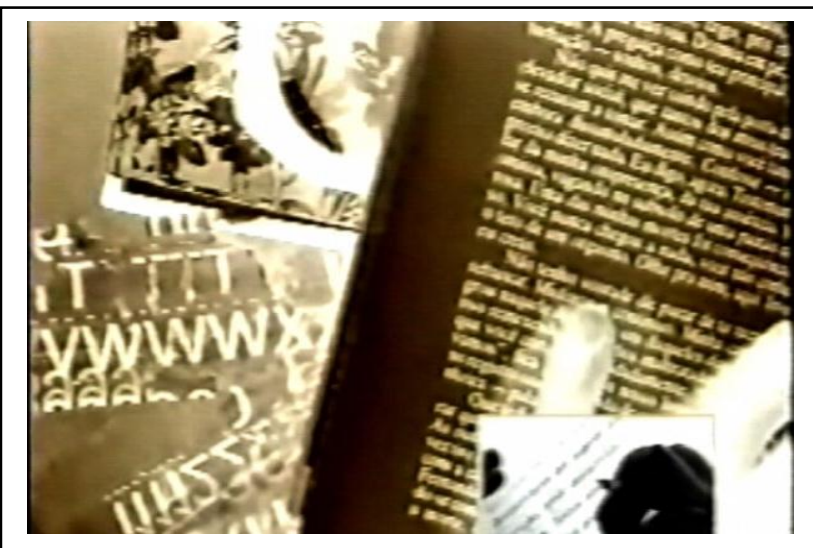

Figura 37: Lapsus Calami.

\subsection{EVENTOS DE TELETRANSMISSÃO QUE OCORRERAM NO PERFORUM DESTERRO}

\section{Dia 23 de setembro de 1999:}

- Antes dos 500

As transmissões foram iniciadas com a proposta de formulação coletiva de uma narrativa interpretada por uma criança em forma de desenho e a pintura da retroprojeção da imagem que vinha de São Paulo sobre uma tela. A ocupação do espaço, assim como a utilização dos recursos, foram os grandes desafios, assim como manter uma narrativa interativa com as frequentes quedas da conexão.

- Participantes: Equipe Perforum São Paulo e Equipe Perforum Desterro; Entre UFSC - USP.

\section{Dia 21 de outubro de 1999}

- Antes dos 501

O roteiro incluiu diversos experimentos que exploraram os recursos plásticos como o espelho que duplicou e deformou a imagem, fragmentando simultaneamente os espaços dos dois terminais; a Videocriatura de Otávio Donasci que simulou o Beijo de Cristal Líquido à distância; os Mecanismos de Risco de Artur Matuck; as 
intervenções orais e performáticas de Alai Garcia Diniz e o diálogo étnico entre os dois caciques.

Logo se verificou que para haver legibilidade a um evento "jornalístico", as explorações plásticas deveriam ser minimizadas. Foi constatado também que representantes de culturas com forte tradição oral têm dificuldade de se expressarem sinteticamente. A gesticulação e a redundância do discurso fazem parte da linguagem desses povos, e que os recursos técnicos, por serem dispendiosos e exigirem a otimização da alocação da sala, acabam por inibir a comunicação.

- Convidados: Cacique Xavante Hiparidi Top'tiro, Cacique Sr. Sebastião da Penha da Comunidade Cafuza em Santa Catarina, Alai Garcia Diniz - Profa. Dra. de Literatura Hispano Americana, Fábio Brügemmann - Poeta e Editor da Letras Contemporâneas;

Participação: Rodrigo Tramonte;

- Mecanismos de Risco de Artur Matuck;

- O Beijo do Cristal Líquido de Otávio Donasci;

Entre UFSC - USP.

\section{Dia 25 de novembro de 1999}

- Fórum Temático na Internet: A Comunicação como Ritual Telestésico.

Participaram do Fórum pela Internet alguns alunos da UDESC no Laboratório de Informática, participantes da Equipe do Perforum São Paulo e Desterro em seus domicílios e o artista Patrick Lichty, nos Estados Unidos.

Entre UFSC - USP - UDESC.

\section{Dia 17 de dezembro de 1999}

- A Economia do Amor: a questão da negra e da mulher gorda.

As duas convidadas, Elisabete Pinto e Fernanda Magalhães, focaram a questão do padrão de beleza vigente que coloca as mulheres negras e as gordas na ponta da pirâmide da solidão. A Economia do Amor através de Elisabete Pinto equiparou as mulheres em geral às prostitutas, por negociarem interesses na escolha de seus parceiros sexuais e de "contratos sociais" como o casamento e demais acasalamentos. 
Fernanda Magalhães expôs através de suas fotos a classificação dos médicos endócrinos das mulheres sob duas formas: a das peras e a das maçãs junto ao desenvolvimento do conceito de volume em Naum Gabo. Para Fernanda, a linguagem legítima da videoconferência foi a Performance, assim ela decidiu abandonar a representação da Mulher Gorda para apresentá-la. Ainda segundo Fernanda, o termo transmissão não foi adequado, pois ambos os pólos desencadearam sentidos e influenciaram o direcionamento de resposta do outro.

- Mecanismos de Risco - Artur Matuck

- Convidados: Elisabete Pinto do FALA PRÊTA, Fernanda Magalhães, fotógrafa e performer e Verceles Amâncio.

Entre TELESC - USP.

\section{Dia 18 de abril de 2000}

- Descobrimentos - concepção Equipe Desterro, Laurette Pasternack e Grupo Fome;

- Convidados: Laurette Pasternack e Grupo Fome;

- Olhos Teleativos de Tereza Labarèrre;

Entre UNIVALI - USP.

\section{Dia 19 de abril de 2000}

- Descobrimentos: Redescobrimentos - performance de Celso Fonseca.

Câmera: Artur Matuck.

Historiadoras Convidadas: Beatriz Mamigonian e Denise de Moura.

Entre UNIVALI - USP.

\section{Dia 29 de maio de 2000}

- O Fantasma da Tela de Daniel Izidoro;

Atores/interatores Convidados: Francisco Capracio, Celso Fonseca;

- Pintura Mural, Pintura Rupestre de Teresa Labarrère e Fernanda Luz;

Participação: Leonardo Romão;

Entre UNIVALI - Sala SONY SP. 


\section{Dia 26 de junho de 2000}

- Teleróides de Artur Matuck.

Por problemas técnicos, foi desenvolvido apenas os Mecanismos de Risco de Artur Matuck. Essa foi a primeira experiência de aula à Distância para os alunos da disciplina de Teoria do Conhecimento da UNIVALI. O Perforum Desterro ofereceu uma aula presencial sobre os equipamentos e sua utilização como recurso plástico nas transmissões, completada telepresencialmente por Artur Matuck que, junto à Performance dos Mecanismos de Risco, desenvolveu o tema sobre Arte e Tecnologia.

Entre UNIVALI - Universidade ANHEMBI-MORUMBI.

\section{Dia 15 de setembro de 2000}

- O Corpo da Letra de Yara Guasque.

Participação: Janaí Pereira, Leonardo Romão, Lucila Vilela, Ana Paula Alves de Souza, Laurette Emilie Pasternak, Marion de Martino, Letícia de Brito Cardoso e Yara Guasque.

Interação em São Paulo Olfabetos e Anabetos: Artur Matuck, Natan Labarrère Mendes, Teresa Labarrère e Brenda Novak.

Explorando a imbricação de uma escrita inserida no corpo, na relação das partes desse com anagramas, e a escrita do tempo nas linhas e traços do corpo.

Entre UNIVALI e Universidade ANHEMBI-MORUMBI.

\section{Dia 31 de outubro de 2000}

- O Corpo no Ciberespaço: Ciborg e Bruxas - organização em São Paulo: Edson Oliveira.

Participação: Lúcia Santaella, coordenadora do Centro de Investigação de Mídias Digitais CIMID, Ivani Santanna, Artur Matuck, Rejane Cantoni.

Sonoplastia: Sistema de Escuta e Deconstrução: Januíbe Tejeira.

Animação: Leonardo Romão.

Produção: Janaí Pereira.

Participação: Cynthia Pimenta, Samara e Yara Guasque.

Entre UNIVALI e PUC/ Oficina de Eventos da USP. 

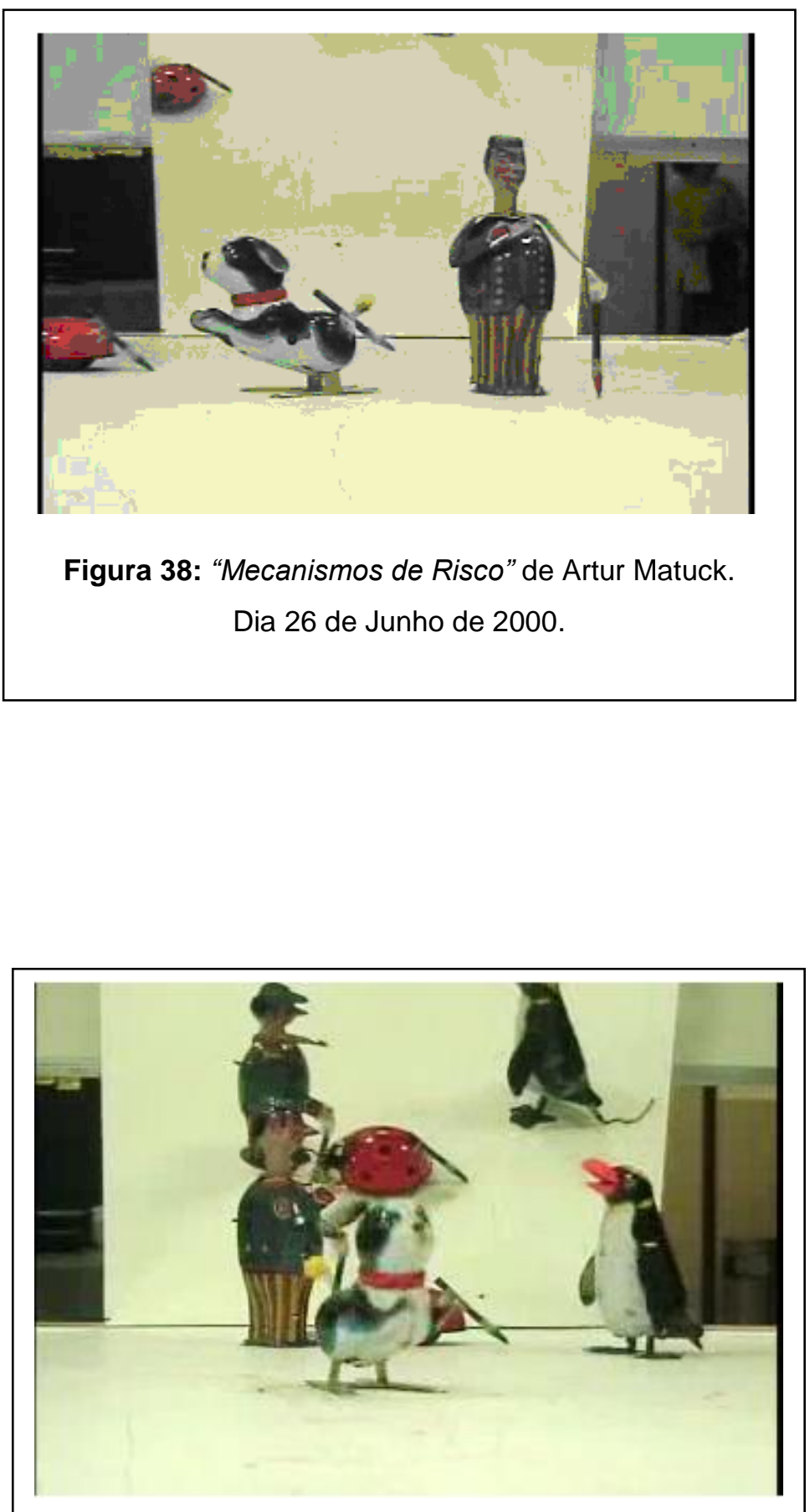

Figura 39: "Mecanismos de Risco" de Artur Matuck. Dia 26 de Junho de 2000. 


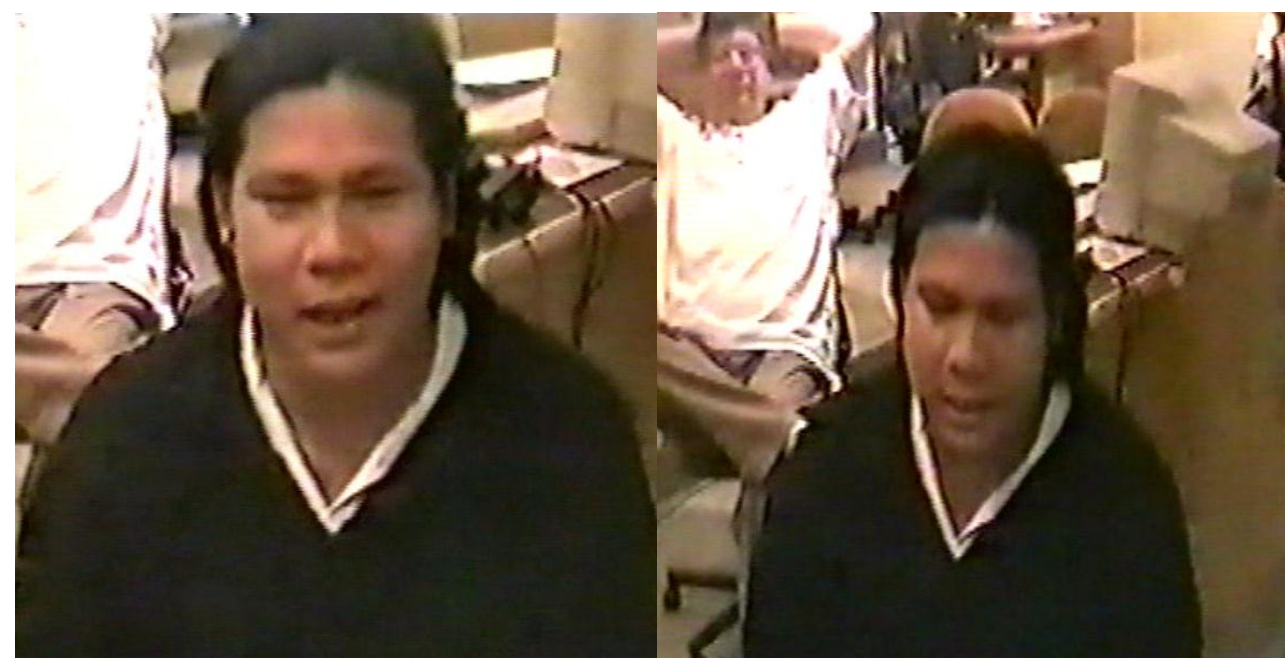

Figuras 40 e 41: Índio xavante Hiparidi Top'tiro participando de uma das teleconferências do Perforum Desterro.

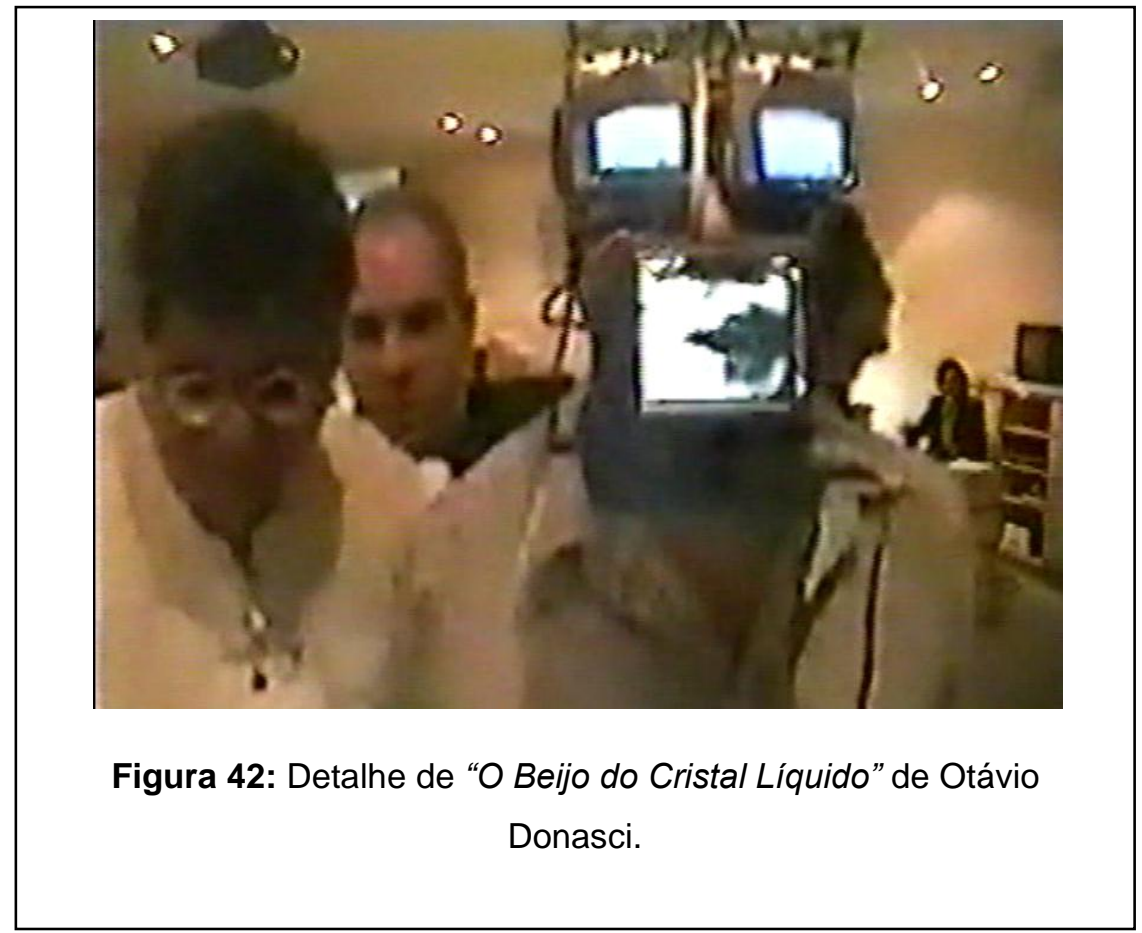




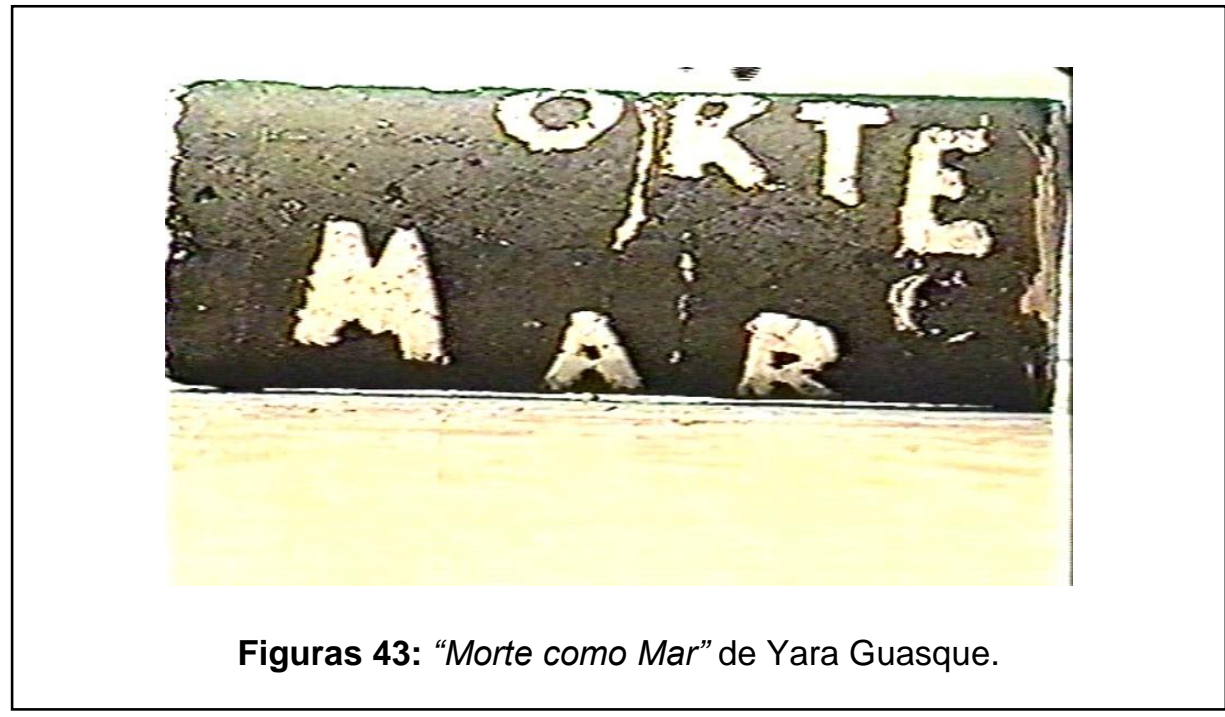

Como desdobramento do Perforum Desterro, Yara Guasque continuou suas pesquisas em telepresença, na Universidade Estadual de Santa Catarina (UDESC).

O grupo Interações Telemáticas nasceu em 2004 como projeto de pesquisa do Centro de Artes da UDESC - Florianópolis. Nossa pesquisa se concentrou no resgate das Teleperformances realizadas pelos grupos Perforum Desterro e Perforum São Paulo nos anos de 1999 e 2001 e na compreensão dos elementos poéticos e técnicos envolvidos em seus trabalhos de Teleperformance (...). ${ }^{56}$

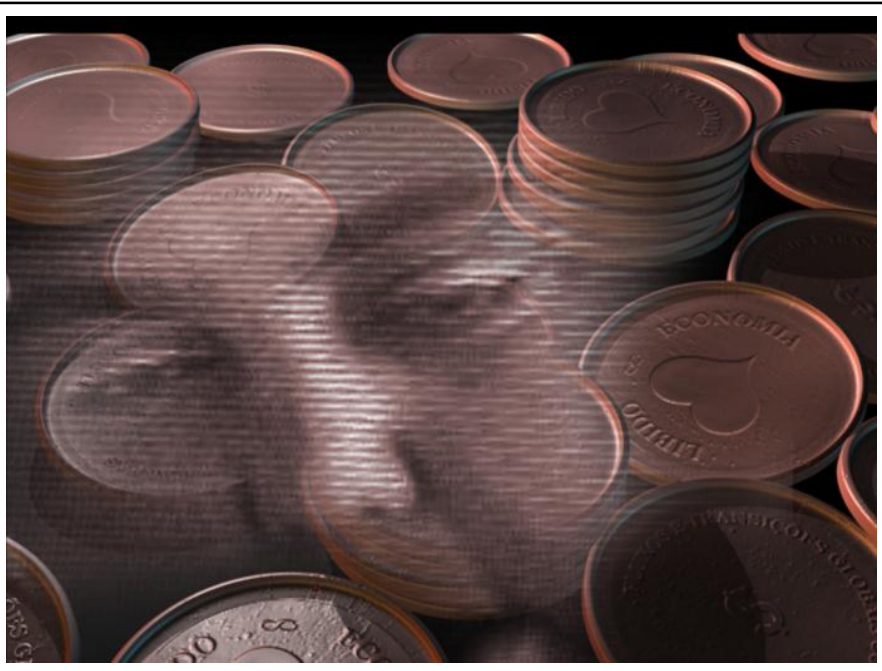

Figura 44: Metáfora LIBIDOECONOMIA, do grupo INTERAÇÕES TELEMÁTICAS (UDESC).

${ }^{56}$ Texto de apresentação da página virtual do grupo Interações Telemáticas, coordenado por Yara Guasque. Disponível em: http://webceart.udesc.br/perforum/. Acesso em 25 de Setembro de 2013. 
6.

\title{
A QUESTÃO DA DOCUMENTAÇÃO E
} PRESERVAÇÃO DA ARTE TELEMÁTICA

\begin{abstract}
A questão do restauro digital é tão complicada quanto a polêmica com o restauro da Santa Ceia de Leonardo da Vinci. O material usado por ele para fazer as cores, tipo de tinta, não era usual da época, e não existe mais. Então como é que, no restauro, você vai reproduzir ou repor as mesmas cores que Da Vinci usou? Obviamente que a Santa Ceia restaurada tem uma probabilidade mínima de ser a mesma Santa Ceia de Da Vinci ${ }^{57}$
\end{abstract}

57 Ismail Xavier - Entrevistas, por Eugênio Pupo e Arthur Autran, IN: A montagem no cinema. São Paulo: Centro Cultural Banco do Brasil, 2012, p. 38. 
No século passado, a arte passou por inúmeras transformações, dentre as quais o fato de não mais imitar a realidade, ou seja, quando deixa de existir o mimetismo na arte, os problemas relacionados à sua preservação aumentam.

Isso ocorreu no início do século XX, quando as vanguardas trouxeram novos questionamentos e buscaram outros suportes, que não eram comuns nas artes, estabelecendo com estes novas relações.

No inicio dos anos setenta já existia por parte de alguns artistas a vontade e a intenção de utilizar meios e procedimentos instantâneos de comunicação e suportes "imateriais". Não se desejava mais trabalhar com o lento processo de comunicação postal, era preciso fazer depressa e diretamente, passar do assíncrono ao sincrônico. $O$ desejo de instantaneidade, de transmissão em direto, as questões de ubiquidade e de tempo real já estavam presente nessa época (...). Nesse período, começava a se estabelecer e a se desenvolver as bases de uma relação entre arte e telecomunicações, com artistas que desenvolviam projetos de ordem global. Nesse período, experiências em arte e telecomunicações proliferaram, utilizando satélites, SSTV, redes de computadores pessoais, telefone, fax e outras formas de reprodução e de distribuição utilizando as telecomunicações e a eletrônica. (PRADO, 1997) ${ }^{58}$.

Partindo desta abordagem acerca dos procedimentos e transformações na condição material da arte, somos levados a pensar sobre as formas mais apropriadas de preservar e documentar uma produção artística tão variada.

Um fator muito relevante na preservação de obras de arte contemporâneas, em particular no caso da Arte Telemática, é a obsolescência dos suportes e dos aparatos tecnológicos necessários para sua produção e reprodução.

$\mathrm{Na}$ Arte Telemática, as escolhas dos instrumentos tecnológicos eram feitas mais pela sua capacidade de comunicação, do que em função da durabilidade dos registros. Assim, problemas com relação à preservação e documentação tornaramse inevitáveis.

58 PRADO, Gilbertto. Cronologia de experiências artísticas nas redes de telecomunicações, in: Revista Trilhas n. 6, v. 1, Campinas: Unicamp, 1997. 
Segundo Laurentiz (2004):

Nos anos 70 e 80 as experiências em arte e telecomunicações se proliferaram, utilizando satélites, SlowScan TV (televisão de varredura lenta), telefone, fax e outras formas de reprodução e de distribuição de informação. Somados posteriormente à eletrônica passamos à utilização de suportes imateriais, altas velocidades, simultaneidade, interatividade, etc. (LAURENTIZ, 2004) ${ }^{59}$.

\subsection{A DOCUMENTAÇÃO E A PRESERVAÇÃO DO CONTEXTO TECNOLÓGICO}

Preservar objetos artísticos significa defender, resguardar, proteger 0 patrimônio para que ele não se deteriore, mas sem intervir no objeto. Ou seja, reter significados de modo a que se possa recriar a forma original ou a função do objeto para assegurar sua autenticidade e acessibilidade.

Mas como estabelecer critérios e metodologias para a preservação da arte contemporânea imaterial, especialmente a Arte Telemática? - Afinal essa arte está intimamente vinculada à performance - e com alto grau de imprevisibilidade e uma permanência efêmera.

As estratégias vão desde a criação de museus tecnológicos, passando por emuladores de equipamentos antigos e migração/ conversão/ transdução de arquivos de equipamentos e softwares para outros meios.

Talvez a mais simples das estratégias seja a conservação do contexto tecnológico utilizado originalmente na concepção dos eventos e/ou registros. Esta estratégia seria, essencialmente, a conservação e manutenção do hardware e software necessários à correta apresentação dos eventos/situações registradas.

59 LAURENTIZ, Silvia. Imagem e (I)materialidade. Texto apresentado no XIII encontro anual da COMPÓS e publicado eletronicamente no CD-ROM dos anais do evento, São Paulo, 2004. 


\subsection{CRITÉRIOS DE PRESERVAÇÃO}

Dentre os critérios para a preservação e documentação de objetos artísticos na contemporaneidade, destacam-se:

- Uma documentação adequada do evento através de fotografias, vídeos, áudios, textos, ilustrações, entre outros;

- A identificação dos diferentes materiais/mídias que compõem o evento em si e sua transmissão;

- O registro do contexto social, do tecnológico, dos processos de criação, de acesso aos materiais, tecnologias e técnicas;

- Deve-se ainda ser estabelecido um limite entre preservação e História da Arte. O papel do preservador é de conservar e resguardar;

- A preservação integral (se possível) dos roteiros utilizados, esboços realizados e das gravações dos ensaios;

- A realização de uma entrevista com o artista. $\mathrm{Na}$ falta dele, deve-se entrevistar o curador, os técnicos ou outros possíveis participantes do evento.

Os critérios de preservação são muito importantes, pois uma obra ou evento quando preservado adquire um status privilegiado e passa a demandar um espaço e uma atenção da critica e do historiador da arte.

O gesto de preservar tem implicações e por esta razão, os critérios devem ser investigados, criticados e atualizados, preferencialmente por uma equipe de profissionais especializados, como restauradores, conservadores, historiadores da arte e artistas, resultando num trabalho interdisciplinar. 


\subsection{DESAFIOS E PROPOSTAS PARA A PRESERVAÇÃo DA ARTE TELEMÁTICA}

A documentação de aspectos tangíveis e, principalmente, intangíveis das poéticas contemporâneas é um dos grandes desafios enfrentados pelos profissionais da preservação.

Luis Fernando Sayão, ao falar sobre a preservação digital, aponta:

O dilema que se instala é que a tecnologia digital coloca a humanidade sob o risco de uma amnésia digital, que já está em curso, ao mesmo tempo em que abre oportunidades extraordinárias em todos os campos - da ciência à arte, do trabalho ao lazer. (SAYÃO, 2005, p.115) ${ }^{60}$.

No caso especifico da Arte Telemática, pode-se apontar uma série de obstáculos que se apresentam:

- Falta de recursos financeiros e ausência de uma atitude governamental séria diante de temas como a preservação e a documentação deste tipo de arte no Brasil;

- Problemas no armazenamento, pois não existem locais apropriados, nem previsão de que instituições ou museus deste tipo estejam sendo planejadas;

- Dificuldade em se assegurar cópias de exibição, além das de arquivos, considerando-se o desgaste dos suportes e registros;

- Constante obsolescência dos equipamentos tecnológicos, dos computadores, dos softwares e dos formatos, exigindo contínuo processo de recuperação através da recopiagem e da migração digital;

Pode-se pensar uma série de soluções possíveis para superação dos obstáculos aqui apresentados. Por exemplo:

60 SAYÃO, Luis Fernando. Preservação digital no contexto das bibliotecas digitais: uma breve introdução.In: MARCONDES, Carlos Henrique et. Al. (Orgs.) Bibliotecas digitais: saberes e práticas. Salvador, BA: EDUFBA; Brasília: IBICT, 2005. Pág.115 
- Uso de fichas documentais mais completas, com descrições técnicas das novas mídias, não para registrar apenas as características físicas e técnicas, mas também o ambiente que o artista quis ressaltar ou criar para suas obras. Assim como acrescentar registros visuais, capazes de salvaguardar a dimensão de espaço e tempo que as constituem;

- Elaborar um desenho (esquema) das instalações físicas de cada evento, o que ajuda a recuperar o aspecto da ambientação projetado pelo artista;

- Incluir descrições de cada material e estrutura, bem como métodos, empresas que os fabriquem ou fabricavam (localização), tipo, marca do equipamento, referência das tintas para impressão, documentação e literatura sobre o projeto (caso exista);

- A documentação em vídeo pode complementar as técnicas de documentação existentes na forma textual. O som e o tempo podem trazer aspectos próprios, que não seriam percebidos em textos, fotos ou desenhos. Até mesmo uma atmosfera residual importante pode aparecer no vídeo;

- Registrar as conversas e, principalmente, as entrevistas com os artistas em áudio, vídeo e fotografias;

- Elaborar um questionário (roteiro) para as entrevistas, dê preferência com o auxílio dos artistas que trabalharam com Arte Telemática, pois estes podem sugerir questionamentos elucidativos, pois partirão de seus próprios problemas;

- Reunir o maior leque documental possível, dentre os quais: documentação iconográfica, tridimensional e textual;

- Identificar o significado do equipamento escolhido para determinado evento e, ao mesmo tempo, monitorar e estudar o comportamento destes equipamentos e mídias ao longo de várias interações e com o passar do tempo. 


\subsection{ESPECIFICIDADES NA PRESERVAÇÃO DA ARTE TELEMÁTICA}

Dentre as características específicas do processo de preservação em Arte Telemática, pode-se dizer que no caso das poéticas da Arte Telemática, verifica-se que os processos de aquisição, documentação, exibição e preservação, não acontecem de modo linear, mas estão interligados, podendo ocorrer de modo simultâneo. Por exemplo, um evento performático telemático ocorre no mesmo momento de sua transmissão e recepção.

Além disso, os eventos telemáticos são bilocalizados e muitas vezes também multilocalizados, o que implicaria na necessidade de documentação em mais de um local e, em consequência, na coordenação e organização prévia entre profissionais das várias localidades envolvidas na teletransmissão.

Muitas vezes, no entanto, os eventos carecem de uma estrutura profissional e resultam do impulso mais imediatista de equipes ou mesmo de artistas isolados que se aventuram na realização de eventos telemáticos, sem muito planejamento prévio.

Disso resulta a extrema importância dos próprios artistas na preservação da Arte Telemática. Torna-se o papel dos artistas, que assumem as funções de preservadores, curadores e por vezes críticos de suas próprias criações.

Eles também podem explicar aspectos relacionados aos materiais usados e ao processo de produção, indicando questões e soluções no tocante à conservação e auxiliando na mesma

\subsection{A IMPORTÂNCIA DE PRESERVAR E DOCUMENTAR OS EVENTOS DE TELEARTE}

Reside na sobrevivência dos objetos (obras ou eventos), através dos tempos, de seus conceitos, ideologias, ideias, representações da história ou da sociedade, experimentações, materiais, técnicas, entre outras.

É a garantia da permanência não só da obra (material), mas do intangível que está relacionado a ela, por exemplo, a interatividade ou a simultaneidade presente em muitas obras contemporâneas.

Através da conservação e da documentação a Arte Telemática, esta passa a ter a sua memória preservada, e seria sem dúvida através dos museus que estes 
procedimentos poderiam ocorrer de modo mais acessível ao público, ou seja, com maior abrangência. Ter acesso ao acervo do artista Artur Matuck significa estar em contato com parte significativa da produção artística contemporânea de São Paulo.

Conservar, restaurar, documentar e divulgar este Acervo, sob diversas formas, significa manter viva a memória da Arte Telemática, preservando-a e respeitando a sua historicidade.

Museus e instituições são capazes, através da divulgação, das exposições e do investimento e abertura para pesquisas científicas, de ativar este patrimônio artístico, que deve ser visto, fruído, interpretado, compreendido e apreciado, caso contrário a conservação das obras perde seu valor primordial.

Os eventos artísticos e seus registros devem ser analisados à luz do seu contexto histórico. Deste modo, eles passam a ser vistos como elementos herdados do passado (patrimônio), capazes de estabelecer este acesso à memória, intrínseco à preservação.

Importante ressaltar que todos os registros são documentos históricos capazes de trazer à tona, através do processo de preservação, uma melhor compreensão acerca dos modos de produção e da prática artística, evidenciando o conhecimento adquirido pelo impulso criativo do ser humano.

No âmbito do patrimônio cultural insere-se a arte contemporânea, especialmente a Arte Telemática, que deveria receber incentivos para sua preservação, haja vista a especificidade, efemeridade e variabilidade de materiais. Deste modo, há necessidade de uma política especifica para a proteção destes acervos, assim como ações efetivas de restauração dos bens que se encontrarem em estado de conservação ruim ou inadequado.

\subsection{COMO PRESERVAR UM EVENTO COMO O PROJETO PERFORUM?}

Nesse trabalho as maiores dificuldades encontradas no tratamento do acervo do Projeto Perforum foram:

- A descentralização entre os participantes pode ser muito interessante para o

evento de modo geral, pois o enriquece, mas no tocante à preservação, isso atrapalha bastante, pois cada participante faz um registro diferente dos eventos, sem 
seguir um critério único, o que dificulta demais o recolhimento e a junção de todo este material, bem como uma análise adequada do conjunto;

- Ausência de uma discussão prévia a respeito da documentação dos eventos e a indicação de um ou mais responsáveis para os registros (fotografias e vídeos, por exemplo);

- A grande dificuldade ao se encontrar os materiais, principalmente pela descentralização destes entre diversas pessoas, que na maioria das vezes encontram-se geograficamente distantes;

- A mudança constante de computadores, algo bastante comum atualmente. As pessoas geralmente mudam de PC com bastante frequência, (diante da rápida obsolescência), e esquecem de armazenar ou de repassar o que estava no PC antigo para o novo. Diante disso, muitos arquivos importantes são perdidos. Como aconteceu com alguns arquivos do Projeto Perforum (como as descrições dos eventos e as fotografias digitalizadas);

- Não transferência de fitas de vídeo antigas (VHS) para dvds ou para arquivos que possam ser lidos em computadores. Deste modo, muitas das fitas perderam-se ou estão prestes a isso. Houve uma tentativa de recuperar parte delas, e estas foram analisadas neste trabalho. Embora a grande parte tenha sido danificada, sem possibilidade de aproveitamento;

- Ausência de fotografias para serem analisadas. Um pequeno número de fotos foi encontrado. Grande parte das imagens foram retiradas dos vídeos;

Acreditamos que antes de haver qualquer evento de Arte, especialmente Telemática, deve ser realizada uma reunião, na qual os temas documentação e preservação fossem abordados. Desta maneira, seriam designadas pessoas responsáveis pela fotografia, filmagem e organização de todos os papéis, desenhos e arquivos criados para definirem o evento, inclusive esboços, rascunhos e e-mails trocados pelos participantes (e estes últimos deveriam ser impressos). Assim, haveria uma definição no modo de registrar e armazenar todas as informações, que seriam alocadas num PC central, com criação de cópias de segurança.

Quando os artistas contemporâneos passarem a se preocupar com o registro e a preservação de suas produções artísticas, poder-se-á garantir que elas permaneçam por mais tempo, a fim de que possam ser analisadas e apreciadas pelas gerações futuras. 


\section{CONSIDERAÇÕES FINAIS}

A partir de uma proposta inovadora de meta-autoria considerando que 0 Projeto Perforum fez um bom uso das novas tecnologias telemáticas que chegavam ao Brasil no final do século XX.

Embora eixos telemáticos como o da "interculturalidade", em oposição ao "choque de civilizações" não tiveram o desdobramento previsto em toda a sua potencialidade - mesmo assim, foram realizados contatos interessantes com os índios xavante e a participação de Elisabete Pinto da ONG Fala Preta - uma entidade dedicada ao desenvolvimento humano sustentável que busca a eliminação de todas as formas de discriminação e violência.

Com os devidos recursos e apoio oficial, o Projeto Perforum seguramente teria sido mais amplo - proporcionando um maior intercâmbio de ideias e valorização do outro. O núcleo temático "travessias oceânicas", por exemplo, ficou prejudicado por falta de apoio aos contatos com Portugal e África.

Mas se o projeto perdeu em abrangência, centrando-se em teleconferências com Santa Catarina (Perforum Desterro) - podemos dizer que esses contatos foram bastante intensos, funcionando como uma verdadeira oficina de experimentação com a telepresença.

Se por um lado o Projeto Perforum materializava conceitos teóricos iniciados por Ascott, por outro o evento motivou a reflexão que deu origem a trabalhos teóricos como a tese de doutoramento de Yara Guasque intitulada "Telepresença: interação e interfaces".

Podemos dizer que mesmo esse nosso trabalho é um desdobramento do Projeto Perforum - servindo como momento de reflexão sobre a recuperação da memória dos eventos realizados em meios digitais. A conclusão a que chegamos é que a profusão de imagens e a facilidade de transmissão são enganosamente permanentes - se levarmos em conta a obsolescência dos meios de registrar a capacidade de armazenamento.

Portanto, esperamos que esse trabalho sirva de alerta para os realizadores e artistas da efêmera arte digital para que se assegurem de formatos mais estáveis, caso desejem que seus trabalhos possam também ser apreciados pelas gerações futuras. 


\section{REFERÊNCIAS}

ARANTES, Priscila. Arte e Mídia no Brasil: perspectivas da estética digital. ARS (USP), v. 3, p. 52-66, 2005. BAIRON, Sérgio. Multimídia. São Paulo: Ed. Global 1995.

ARAÚJO, Yara Rondon Guasque. Telepresença: interação e interfaces. São Paulo: Educ/FAPESP, 2005.

\begin{tabular}{ll} 
& \multicolumn{2}{c}{ TELE-EVENTO-PENSAMENTO: a imagem } \\
\hline mediada na videoconferência e na telepresença. & Em \\
http://pages.udesc.br/ c2yrga/9yara.htm - aceso em 31 de Agosto de 2013.
\end{tabular}

http://pages.udesc.br/ c2yrga/9yara.htm - aceso em 31 de Agosto de 2013.

Perforum Desterro e Perforum São Paulo:

Reconsiderando a colaboração entre a periferia e os centros. Em http://webartes.dominiotemporario.com/performancecorpopolitica/ - acesso em 31 de Agosto de 2013.

ARRIGHI, Giovanni. O Longo Século XX. São Paulo: UNESP, 1996.

ASCOTT, R. Art and Telematics: towardsa network consciousness. In: UNDMANN,H. (Ed.) Art+telecommunication. Viena: Shakespeare Co., 1984.

Telematic Embrace: visionary theories of art, technology, and consciousness. Los Angeles: University of California Pree, 2003.

BARTHES, Roland. The Pleasure of the Text. New York: Hill \& Wang, 1975.

BIOCCA, Frank e Mark R. Levy. Communication in the age of virtual reality. UK: Lawrence Erlbaum Associates, 1995.

CAMÕES, Luís de. Os Lusíadas, Canto I, 1-2.

CARVALHO, Karin Magnavira de. Arte Telemática no Brasil: panorama dos eventos de arte-comunicação nas décadas de 80 e 90. Dissertação (mestrado) Universidade de São Paulo. SP: 2012.

CASTELLS, Manuel. The Rise of network Society. OUP: NY, 2000.

CERVO, Amado e BUENO, Clodoaldo. História da Política Exterior do Brasil. Brasília: Ed. UNB, 2002.

COELHO, Teixeira. Dicionário Crítico de Política Cultural. São Paulo: Ed. lluminuras, 2004.

COUCHOT, Edmond. Dialogues sur l'art et La technologie. Universidade de Paris 8, 1998. 
DOMINGUES, Diana (org.). A Arte no Século XXI. São Paulo: UNESP, 1997.

Experimento, 2002.

Criação e Interatividadena Ciberarte. São Paulo:

DUPAS, Gilberto. Atores e Poderes na Nova Ordem Global: assimetrias, instabilidades e imperativos de legitimação. São Paulo: Ed. Unesp, 2005.

ELLIOTT, J.H. Imperial Spain; 1469-1716. London: Pengoin Books, 1990.

FERREIRA, Edemar Cid. "Arte Barroca" - Catálogo da Mostra do Redescobrimento - Brasil + 500 anos, Artes Visuais, 2000.

FONTCUBERTA, Mar de \& MOMPART, Joseph, L. Gomes. Alternativas de Comunicacíon. Barcelona, Miltre, 1983.

GONÇALVES, Lisbeth. Entre Cenografias - 0 Museu e a Exposição de Arte no Século XX. São Paulo: Edusp, 2004.

GUIMARÃES, Samuel Pinheiro. Quinhentos Anos de Periferia: uma contribuição ao estudo da política internacional. In: Desafios Brasileiros na Era dos Gigantes, Rio de Janeiro: Contraponto, 2005.

HAASS, Richard N. The Age of Nonpolarity - what will follow US dominance? Em http://www.foreignaffairs.com/articles/63397/richard-n-haass/the-age-ofnonpolarity - Acesso em 27 de Abril de 2013.

HALL, Stuart. A identidade cultural na pós-modernidade. Rio de Janeiro: DP\&A, 2006.

HOBSBAWN, Eric. The Age of Extremes. New York: Vintage Books, 1994.

HUNTINGTON, Samuel. O Choque de Civilizações e a Recompensa da Ordem Mundial. Rio de Janeiro: Ed. Objetiva, 1997.

IKENBERRY, G. John. Liberal Order \& Imperial Ambition. Cambrigde: Polity, 2006.

INSTITUTO Sócio Ambiental. Povos Indígenas no Brasil - 1996/2000. São Paulo: ISA, 2000.

JAMESON, Frederic (1991:1996). Vídeo. IN: Pós-modernismo, a lógica cultural do capitalismo tardio. Tradução de Maria Elisa Cevasco. São Paulo: Ática, pp. 91118.

KAC, Eduardo. A Arte da Telepresença na Internet. In: DOMINGUES, Diana. A Arte do Século XXI. São Paulo, UNESP. Disponível em www.ecac.org/kac2.html. Acesso em 16 de junho de 2013.

KEOHANE, Robert O. After Hegemony. Princeton: Princeton University Press, 1984. 
KRAUTHAMMER, Charles. The Unipolar Moment. ForeignAffairs, 70.

KRENAK, Ailton. WAMRÊMÉ ZA'RA. Mito e História do Povo Xavante: Nossa Palavra. São Paulo. Editora Senac, 1998.

LAURENTIZ, Silvia. Imagem e (I)materialidade. Texto apresentado no XIII encontro anual da COMPÓs e publicado eletronicamente no CD-ROM dos anais do evento, São Paulo, 2004.

LEEUWENBERG, Frans; SALIMON, Mário. Para Sempre A'uwẽ: os Xavante na balança das civilizações. Brasília DF, 1999.

LEÃO, Lucia. O Labirinto da Hipermídia. São Paulo: Iluminuras, 1999.

LEVY, Pierre. Cibercultura. São Paulo: Editora 34, 1999.

LINHARES, Marra Yedda (org). História Geral do Brasil. Rio de Janeiro: Elsevier, 2000.

MATUCK, Artur. O Potencial Dialógico da Televisão - Comunicação e arte na perspectiva do receptor. São Paulo, Anna Blume e Eca-USP, 1996.

"Telesthesia - The Aesthetic of Scalar Communication". in: Art Reseaux. Coord. Karen O'Rourke, Editions DUCERAP, Centre D'Études et de Recherches en Arts Plastiques, Université de Paris I, Pantheon - Sorbonne, Paris, 1992.

Memorial de Artur Matuck. Memorial apresentado à Escola de Comunicações e Artes da Universidade de São Paulo como requerimento parcial para concurso de Livre-doscência. São Paulo 2006.

MATUCK, Artur e Reis, Hiliana. Perforum Descobrimentos: Telearteciência São Paulo/Barcelona. IN: Educação para a Ciência: curso para treinamento em centros e museus de Ciências. Coord. Crestana Silverio. São Paulo: Editora Livraria da Física, 2001.

MATUCK, Artur e ANTONIO, Jorge Luis (org). Artemídia e Cultura Digital. São Paulo: Musa editora, 2008.

MELLO, Christine. Extremidades do Vídeo. São Paulo: Editora Senac. São Paulo, 2008.

NOVAES, Adauto (org). A Outra Margem do Ocidente. São Paulo: Companhia das Letras, 1999.

NYE, Joseph S. O Paradoxo do Poder Americano. São Paulo: Ed. UNESP, 2002.

PALUMBO, Maria Luisa. Lucinda Byatt (trad.). New Wombs. Electronic bodies and architectural disorders. Basel, Birkhäuser, 2000. 
PRADO, Gilbertto. Cronologia de Experiências Artísticas nas Redes de Telecomunicações, in: Revista Trilhas n. 6,v. 1, Campinas: Unicamp, 1997

. "Experimentações Artísticas em Redes Telemáticas e Web". IN: Interlab: labirintos do pensamento contemporâneo. Coord. Lucia Leão. Editora lluminuras, São Paulo, 2002, p.115-125.

Arte Telemática: dos intercâmbios pontuais aos ambientes virtuais multiusuário. Itaú Cultural, São Paulo, 2003.

PREZIA, Benedito e HOORNAERT, Eduardo. Brasil Indígena - 500 anos de Resistência. São Paulo - FTD, 2000.

QUAGLIATO, Adriana Novaes. Mostra do Redescobrimento: Arte Barroca e Espetacularização. Dissertação (mestrado) - Universidade Estadual de Campinas, Instituto de Artes. Campinas, SP: 2007.

RAMINELLI, Ronald. Viagens Ultramarinas: Monarcas, vassalos e governo a distância. SP, Editora Alameda, 2008.

RURI'Õ, Lucas/BIASI, Helena Stilene de. A História da Aldeia Abelhinha. São Paulo: Master Book, 2000.

SANTAELLA, Lucia. Cultura das Mídias. São Paulo: Experimento, 1996.

Culturas e Artes do Pós-humano: da cultura das mídias à cibercultura. São Paulo: Paulus, 2003.

Paulus, 2004.

. Corpo e Comunicação: sintonia da cultura. São Paulo: Paulo: Paulus, 2004.

Navegar no Ciberspaço: o perfil do leitor imersivo. São

SANTOS, Milton e outros (Orgs). Fim do Século e Globalização. São Paulo: HUCITEC/ANPUR, 1993

SANTOS , Milton - Por uma outra Globalização: do pensamento único à consciência universal, Rio de Janeiro, Record, 2009.

SAYÃO, Luis Fernando. Preservação digital no contexto das bibliotecas digitais: uma breve introdução. In: MARCONDES, Carlos Henrique et. Al. (Orgs.) Bibliotecas Digitais: saberes e práticas. Salvador, BA: EDUFBA; Brasília: IBICT, 2005.

SEHN, Magali Melleu. A Preservação de Instalações de Arte com ênfase no contexto brasileiro: discussões teóricas e metodológicas. 2010. Tese (Doutorado em Artes) -Escola de Comunicações e Artes -USP. 
SILVA, Aracy Lopes da. Nomes e Amigos da prática xavante a uma reflexão sobre os Jê. São Paulo, FFLCH/USP, 1986.

SILVA, Francisco Carlos Teixeira da. Brasil, em direção ao século XXI. In: LINHARES, Maria Yedda. (Coord.). História Geral do Brasil. 9. ed. Rio de Janeiro: Elsevier, 2000.

SEREBURÃ/HIPRU/RUPAWÊ/SEREZABDI/SEREÑIMIRÃMI. Wamrêmê za'ra, Nossa Palavra: Mito e História do Povo Xavante. São Paulo: Senac, 1998).

SILVA, Kelly Cristiane da. A Nação Cordial: uma nálise dos rituais e das ideologias oficiais de "comemoração dos $\mathbf{5 0 0}$ anos do Brasil". Rev. Bras. Ci. Soc. vol.18 no.51 São Paulo Feb. 2003. Disponível em http://www.scielo.br/scielo.php?pid=S010269092003000100010\&script=sci arttext\#backast - acesso em 31 de Agosto de 2013.

THOMÁS, Luís Filipe. De Ceuta a Timor. Lisboa: Difel, 1994.

VISENTINI, Paulo G. Fagundes. História do Mundo Contemporâneo. Petrópolis: Ed. Vozes, 2008.

YANOMAMI KOPENAWA, Davi. Descobrindo os brancos. In: NOVAES, Adauto, A outra margem do Ocidente. São Paulo: Minc-FUNARTE/Companhia das Letras, 1999, p. 15-21.

WALLERSTEIN, Immanuel. Após o Liberalismo. Petrópolis: Ed. Vozes, 2002.

WELLAUSEN, Saly da Silva. Terrorismo e os Atentados de 11 de setembro. Tempo Social; Rev. Sociol. USP, S. Paulo, 14(2): 83-112, outubro de 2002. Acesso em 17 de abril de 2011 - http://www.scielo.br/pdf/ts/v14n2/v14n2a05.pdf.

ZANINI, Walter. A arte de comunicação telemática - a interatividade no ciberespaço. In: ARS - Revista do departamento de Artes Plásticas ECA/USP Ano1, $n^{\circ}$ 1. São Paulo, ECA/USP, 2003. p. 11-34. 
ANEXOS 


\section{Projeto Perforum: Desenhando Fluxos de Informação e Conectando Culturas}

Prof. Dr. Artur Matuck

Escola de Comunicações e Artes

Universidade de São Paulo

Junho 2000

1 Introdução

2 Escrituras mediáticas

3 Projeto Perforum: um metatexto

3.1 Conceituação

3.2 Estrutura

3.3 Objetivos 


\section{Introdução}

O Projeto Perforum foi concebido e apresentado por Artur Matuck e equipe Perforum São Paulo, da Escola de Comunicações e Artes da Universidade de São Paulo, em colaboração com Yara Guasque e equipe Perforum Desterro, do Departamento de Artes Plásticas do Centro de Artes da Universidade Estadual de Santa Catarina, Florianópolis, Santa Catarina. Perforum foi aprovado pela PróReitoria de Cultura e Extensão Universitária para participar oficialmente nas comemorações na USP dos 500 anos do Brasil e pela Secretaria do Estado da Cultura do Estado de São Paulo, merecendo a chancela da Comissão Paulista dos 500 anos.

\section{Escrituras mediáticas}

A fundamentação teórica do Projeto Perforum segue um conceito de autoria em criação mediática desenvolvido em obras contemporâneas de arte e tecnologia.

Este conceito desdobra o processo de criação em estágios distintos e sucessivos: o primeiro estágio, chamado meta-texto (ou pré-texto), atua como gerador, determinador do segundo, o texto propriamente dito, que enuncia o metatexto. No terceiro estágio, o pós-texto, o texto enunciado é editado, re-escrito, comentado e preparado para divulgação e publicação.

Propõe-se, assim, uma metodologia de criação e produção mediática. No primeiro nível, estabelece-se um metadiscurso, uma espécie de partitura mediática, que determina, planeja e direciona as interfaces operacionais entre o criador, seus processos escriturais, seus instrumentos, programas e eventuais colaboradores.

Segundo este protocolo, os trabalhos a serem realizados seguirão diretrizes pré-determinadas de ordem processual, conceitual, tecnológica e computacional, que constituem o metatexto. O metatexto tem portanto a função de orientar atos performáticos de expressão estética, procedimentos de organização de informações, processos generativos de sequências significantes ou sistemas de produção coautorada. 
Esta conceituação do processo criativo busca evidenciar um estágio implícito do pensamento, o esquema estruturador de uma obra, tornando-o explícito. Ao mesmo tempo, o metatexto constitui-se num texto autônomo com linguagem, estilo, grafia e estética próprias e deste modo poderá ser considerado como um elemento do discurso em sua totalidade, podendo ou não ser incluído na versão final editada, conceituada como o pós-texto.

Neste processo autoral, o criador atua inicialmente como meta-autor, concebendo e escrevendo o metatexto em sua forma definitiva. Posteriormente, como artista procedimental, o mesmo autor ou os co-autores produzem o trabalho, isto é, escrevem o texto, segundo o projeto metatextual. As diretrizes deste projeto, no entanto, não devem impor restrições imperativas: cada procedimento sugere, propõe, desenha as estratégias processuais que orientam ou modificam os fluxos criativos, mas que apenas parcialmente pré-determinam conteúdos.

É provável, no entanto, que durante o processo de se produzir o trabalho, de se atualizar as diretrizes previstas no metatexto, a prática atue reflexivamente, provocando uma possível reelaboração do metatexto. Neste caso ocorre um processo de realimentação que enriquece e aprimora o processo.

Além disso, pode-se identificar diversos níveis meta-textos, textos, e póstextos, que se desdobram em níveis hierárquicos. São escrituras que determinam novas escrituras, planejamentos que orientam planejamentos mais detalhados, processos que sugerem procedimentos de criação individual ou coletiva, que são ao final editados, revisados, preparados para serem divulgados seja em conferências, em publicações impressas ou em sítios computacionais.

Esta tem sido a experiência de se atualizar o Projeto Perforum. Dada a abrangência do metatexto original, a textualização do Perforum, tem exigido um trabalho contínuo de planejamento, produção e roteirização realizado interativamente entre os terminais participantes nas transmissões.

Este tem sido um processo inédito e mesmo imprevisível. O planejamento interativo de eventos de teletransmissão não tem ainda um cânone estabelecido de regras e procedimentos. Portanto a experiência do Perforum, neste campo abre perspectivas para o estabelecimento desta linguagem metatextual interativa na qual dois grupos distantes conduzem, previamente às teletransmissões, reuniões presenciais ou telepresenciais preparatórias, visando ao planejamento e roteirização das conexões. Neste sentido, a documentação resultante da experiência do Projeto 
Perforum, revelará também a emergência desta linguagem metatextual interativa, os traços desta experiência, deste desafio de se planejar interativamente.

\section{Projeto Perforum: um metatexto}

\subsection{Conceituação}

O Projeto Perforum visa integrar telecomunicação, design, educação, artes plásticas e performance, na realização de um evento telemático intercultural de longa duração congregando indivíduos, artistas, escritores, teóricos e humanistas brasileiros, índios, europeus, africanos, e americanos.

Seu conceito fundamental é o da interação dialógica entre criadores, indivíduos, intelectuais, representantes de países, regiões, etnias e culturas distantes que participaram do movimento das Navegações, da Constituição Étnica e Cultural das Américas e especialmente do Brasil.

Perforum propõe que a reflexão construtiva e estética acerca do entrechoque cultural da Conquista se manifeste, na atualidade, também no descobrimento do ciberespaço. A celebração do processo histórico das Navegações se dará, portanto, no presente, através da interação cultural, marcada pela telecomunicação, pela telepresença, pela arte interativa, pelos processos de autoria coletiva.

Deste modo, os indivíduos criadores serão convidados não apenas a refletirem sobre a história da Conquista das Américas no século XVI, mas também sobre a civilização emergente do século vindouro, sobre as possibilidades do ser humano diante da revolução tecnológica.

Estes indivíduos serão portanto desafiados a pensarem a interação entre o homem e a máquina, entre a expressão individual e a co-produção humana-digital, entre a escala individual e planetária, a refletirem acerca da emergência do multi- e o inter-linguístico nos processos telemáticos, a iniciarem uma outra colonização, a invenção do ciberespaço.

Perforum projeta assim uma navegação seminal pesquisando as consequências do virtual sobre o atual, do possível sobre o real, desenhando uma nova cartografia do contemporâneo. 


\subsection{Estrutura}

Perforum se estrutura a partir de ações virtuais, pedagógicas, telemáticas, combinadas entre si, visando integrar processos digitais com eventos localizados no contexto físico e geográfico.

Perforum Virtual instaura-se a partir de um sítio computacional que implanta, organiza e divulga o Projeto em sua totalidade. O sítio conterá uma descrição do Projeto, uma documentação dos eventos realizados, um informativo atualizado, além de um espaço interativo, com um fórum de debates, um banco de proposições estéticas sugeridas, e um mapa das conexões atuantes.

Perforum Pedagógico instaura-se a partir de um projeto de ensino presencial, virtual e telemático que busca oferecer oficinas, instrução programada, encontros e eventos para comunidades e indivíduos interessados em vivenciar a telearte e motivados a reescrever a história do Brasil a partir de uma perspectiva contemporânea. Estas oficinas visam fornecer tanto uma formação histórica e teórica em arte contemporânea, telecomunicação e ciberespaço, como uma prática artística experimental através de teleperformances, videoconferências e telecomunicação digital.

Perforum Telemático projeta uma série de contatos videotelemáticos possibilitando o intercâmbio de textos, imagens, conferências, performances e outras manifestações. Para a realização destes eventos será formada uma rede internacional de artistas e instituições. Estações de teletransmissão especialmente equipadas serão utilizadas nestes projetos e eventos. Perforum Telemático prevê três modalidades de utilização criativa dos sistemas de videocomunicação: $\underline{\text { videoconferências, }}$ teleperformances e eventos de telepresença.

Perforum Documental prevê ainda a documentação destes eventos e obras, a reflexão e avaliação, e posteriormente, a edição de um catálogo, num sítio computacional, em CD-Rom e em mídia impressa.

\subsection{Objetivos}

Refletir acerca do movimento das Navegações do Século XVI, de maneira crítica e inovadora, enfatizando a criação artística colaborativa, através do ciberespaço. 
Valorizar o ser humano como criador e transmissor de ideias, informação e manifestações teóricas e artísticas, integrando-o na rede internacional de telecomunicação.

Criar elos/conexões entre indivíduos, artistas, escritores, teóricos e humanistas de várias partes do mundo, buscando valorizar a colaboração, a interação e a co-criação.

Proporcionar intercâmbio de ideias, conceitos e posicionamentos, buscando a difusão cultural, o conhecimento mútuo, e a valorização do Outro.

Manifestar linguagens da arte que investigam a interação dinâmica entre agentes humanos, processos computacionais e tecnologias de telecomunicação. 
Entrevista realizada em 04 de Abril de 2013 no CRP-ECA com o auxilio de Renata Wrobleski (responsável pela gravação, que foi concedida pelo Departamento de Relações Públicas, Propaganda e Turismo da ECA-USP).

Duração: 01:32:16

\section{Transcrição da entrevista com Artur Matuck e Edson de Oliveira}

Thaís: Como e quando surgiu o Perforum e quem criou esse nome?

Prof. Artur Matuck: Pois é, o nome Perforum fui eu mesmo que inventei. E a primeira ideia para o evento Perforum surgiu quando eu estava em Tallahassee, que é uma cidade da Flórida, numa universidade da Flórida... não lembro o nome agora... eu acho que é "the south of Florida". Cidade da Flórida do Sul, eu estava com minha ex-esposa chamada Maria Aparecida a Silva. Era assim 91, 92 e ela veio assim "adivinha o que aconteceu?!" e eu falei: "não sei não sei”. Daí ela falou assim: "adivinha! A coisa mais incrível do mundo! Nós fomos convidados para a Bienal em Veneza. Daí eu falei: Uau! Que incrível, não é? $E$ naquela época eu estava super envolvido com telecomunicação e arte, uma oficina de telecomunicação e arte. Isso foi logo depois do Projeto Refluxo, e durante o Projeto Refluxo, quando eu morava em Pittsburgh e eu trabalhava junto com a Maria Aparecida da Silva, e a gente fez o Projeto Refluxo praticamente juntos, eu e ela, na Carnegie Mellon University, e o Projeto Refluxo teve muita repercussão, assim, envolveu 100 artistas do mundo inteiro. Então, eu fiquei conhecido como um artista de telecomunicação e arte. E daí, esse professor da Universidade da Flórida em Tallahassee, ele entrou em contato comigo por email, e eu falei para ele quando eu estava na Carnegie Mellon, eu falei que eu estava voltando para o Brasil, porque o meu estágio na Carnegie Mellon tinha terminado e ele participou um pouco do Projeto Refluxo, mas daí eu fui convidado por ele para ir à Flórida dar esse Workshop de telearte, e naquela época telearte era uma coisa... parecia muito de vanguarda, porque era antes da internet, tipo no inicio da década de 90 . Daí veio esse convite para a gente fazer um trabalho em Veneza. E daí eu fiquei estimulado, assim pensando... o trabalho nunca aconteceu, eles falaram: "ah, não está dando certo", mas a palavra Perforum saiu daí e a primeira ideia para o Perforum era mais ou menos o seguinte, a ideia tinha 
uma relação com o lugar público de Londres, onde num tipo de um púlpito, numa praça em Londres, que eu não vou saber exatamente qual é, existe um púlpito, que dizem que é o púlpito da livre expressa. Que qualquer pessoa pode subir naquele púlpito e falar o que eles quiserem, entendeu? Eu penso assim, que isso é uma fachada da Inglaterra, a Inglaterra quer aparecer como um pais livre, de livre expressão, o que eu acho que na verdade não é, mas é o que eles querem aparecer como, é um tipo de um trabalho de Relações Públicas. E a minha ideia do Projeto Perforum dessa época, como ele foi concebido era fazer um tipo de um púlpito virtual em Veneza, em que pessoas que quisessem se manifestar, falar politicamente especialmente, elas mandariam suas mensagens ou falariam a distancia e essas mensagens seriam veiculadas na Bienal de Veneza, vindas de vários países, de várias localidades, de várias pessoas. Então, eu acho que por ai eu pensei na palavra fórum e daí por uma livre associação eu imaginei que esse trabalho poderia se chamar Perforum e daí que surgiu essa terminologia, que eu acho essa palavra extremamente sonora, muito positiva e eu acho que a palavra em si teve um efeito no desenvolvimento do Perforum, mesmo que aconteceu em 99, 2000 aqui na USP.

Thaís: E quais eram os participantes inicialmente?

Prof. Artur Matuck: Pois é, não sei. Tiveram inúmeros participantes. O Projeto Perforum como ele realmente aconteceu, ele surgiu num curso de arte telemática que eu ministrei aqui na ECA, e eu lembro que uma das alunas foi a Yara Guasque. E ela logo se entusiasmou com o Projeto Perforum, e naquela época para a gente viabilizar o Projeto Perforum a gente procurou sistemas de vídeo-conferência. Então para mim, na minha história pessoal e nos trabalhos de telearte que eu já tinha feito. Eu fiz primeiro Intercities, com televisão de varredura lenta e depois nos EUA eu fiz outros com televisão de varredura lenta, slow scan television. E, 91,92 eu tive acesso ao videofone na Bienal de São Paulo, uma pessoa que eu conheci em Toronto, quando ele soube que eu ia participar da bienal de São Paulo em 91. Ele me emprestou um vídeo fone. Ele se encontrou comigo no aeroporto de Toronto, e o meu voo para São Paulo de Pitsburg passava por Toronto, assim que eram os voos mais baratos que vinham do Canadá para São Paulo. E a gente combinou e a gente se encontrou no aeroporto e ele me deu o aparelho e eu trouxe para São Paulo para participar da bienal de São Paulo. Então eu tinha feito experiência de arte a distância 
com televisão de varredura lenta e depois no Projeto Refluxo eu usei o videofone. Então, o meu objetivo era usar a videoconferência. E daí a gente começou a pesquisar como era possível usar a vídeo conferência e tudo o mais, e a gente descobriu que na USP mesmo tinha sistema de vídeo conferência e um mais acessível para nós que eu não vou lembrar exatamente, mas que se tornou acessível para a gente era uma sala de vídeo conferências na faculdade de Economia e Administração. Eu lembro que a gente conseguiu acesso, e a bibliotecária, eu teria que pesquisar para lembrar o nome dela exatamente, mas ela ficou muito entusiasmada e a gente explicou que o nosso objetivo era fazer conexões entre as culturas que não estariam participando das comemorações dos 500 anos da descoberta do Brasil, que seriam os índios e os negros brasileiros basicamente. Então ela franqueou o uso para a gente e começamos a realizar uma série de vídeo conferências e conforme as pessoas foram se agrupando e realmente realizando as vídeo conferências, o nosso principal parceiro ficava em Florianópolis e a pessoa da Yara Guasque, da UDESC - Universidade de Santa Catarina se não me engano, ela era e imagino que ainda é professora lá no departamento de artes e ela aceitou participar, fez um grupo de pesquisa e criou digamos, uma estação terminal que ela colocou o nome de Perforum Desterro. Então, o Perforum no final ele gostaria de ter sido mais amplo, não é, por exemplo, eu tentei contatos com Portugal. Eu queria discutir essa questão do negro e do índio, dos 500 anos do Brasil, supostos 500 anos do Brasil segundo os portugueses e a versão oficial da estória do Brasil enxerga que são os 500 anos do Brasil, eu queria discutir essa questão com artistas e intelectuais portugueses, e eu lembro que um professor de literatura portuguesa da USP que é um senhor português que eu fiz amizade com ele, chama Ernesto de Melo e Castro, ele chegou a ir para Portugal e eu não lembro se eu dei uma cópia do projeto e ele disse que falou com pessoas em Portugal e disse que ninguém estava interessado em participar de um projeto dessa natureza, porque idealmente teria sido interessante para o Projeto Perforum se tivesse havido vídeo conferências com Portugal, mas isso nunca foi possível. Bom, além da Yara em Florianópolis eu lembro que eu procurei lideranças indígenas daqui de São Paulo. Então eu fui numa palestra do Hiparidi, que é um xavante, que na época surgiu assim como uma liderança em São Paulo e eu fui conhecê-lo, eu soube que ele ia dar uma palestra ou ia ter uma participação numa mesa, eu fui conhecer no Palas Athena, que é um instituto que dá oportunidade de várias culturas se 
manifestarem, um instituto de filosofia, que ficava na rua Leôncio de Carvalho se não me engano, próximo da Avenida Paulista, do Itaú Cultural, e lá eu encontrei uma senhora chamada Edméia Jafet, o Edson estava participando comigo, e ai através da Edméia eu fui apresentado para o Hiparidi, líder xavante e expliquei para ele pessoalmente o projeto e ele me deu os telefones dele e daí a gente começou a fazer contato e foi um contato bem frutífero. E na época quem mais participava? Você participava, não é? Da organização.

Edson: Sim, e a Teresa...

Prof. Artur Matuck: A Teresa Labarrére. Ela não foi minha orientanda, mas ela se tornou minha amiga, acho que ela chegou a ser minha aluna da pós- graduação nesses cursos. Ela colaborou bastante. Quer dizer, quem dirigia aqui em São Paulo era eu, a Teresa, você... quem mais? Não lembro quem mais...

Edson: O Donasci participou bastante também.

Prof. Artur Matuck: O Otávio Donasci participou.

Edson: Das performances, das transmissões ele participou.

Prof. Artur Matuck: Ele participou de uma mesa redonda que teve que foi bem legal, que se chamava O Ciborg e o Indígena, esse daí eu tenho o título pelo menos. Foi uma mesa redonda que aconteceu na USP e eu lembro que o Otávio, como ele é muito capacitado para criar sistemas midiáticos, que eu chamo de mídia tectura, eu lembro que ele tinha uma ideia para misturar a linguagem da vídeo conferência com a linguagem do fax, isso a gente pode depois explicar, mas era assim como se dois espaços estariam conectados por vídeo conferência, por vídeo e áudio e ao mesmo tempo também por fax, assim você estaria vendo um fax entrar através da imagem da vídeo conferência e de repente entrar na máquina do fax e de repente você via aquele mesmo fax chegando no seu espaço, que eu acho que seria um evento bem legal de ter acontecido, mas nunca foi realizado. Além disso, depois tiveram as próprias vídeo conferências, na maioria das vezes, todas as vezes acho em Florianópolis, em vários locais em Florianópolis, em São Paulo na USP e também na 
Anhembi Morumbi, a gente fez uma conferência em que participou eu, você e a Teresa com aqueles bonequinhos de corda. Esse eu tenho, esse vídeo.

Edson: E também tem aquela integração no sitio da Paula.

Prof. Artur Matuck: No sitio da Paula e depois no sitio da Edméia. Antes no sito da Edméia. Então, uma das ideias que a gente teve, foi de ter contato, valorizar, conhecer a cultura indígena brasileira através desse líder xavante chamado Hiparidi. Qual é o nome inteiro do Hiparidi?

Edson: Hiparidi, Top'tiro.

Prof. Artur Matuck: Top'tiro?

Edson: Sim.

Prof. Artur Matuck: Então, ele se tornou uma pessoa assim, companheiro, acessível e a Edméia Jafet já tinha um trabalho com ele, não sei se ela é antropóloga ou... não sei exatamente, e a gente teve a ideia de fazer oficinas de cultura indígena brasileira. Então ele deu uma oficina no sitio da Edméia, que sei lá ele teria que recuperar o nome exato da cidade onde foi isso.

Edson: Jaguariúna.

Prof. Artur Matuck: Jaguariúna. E lá eu lembro que a gente fazia uma fogueira e se reunia em volta da fogueira, ele assava carne na fogueira e também batata, e tinha uma maneira e ai ele contava, e daí nesse dia ele falou: "agora eu vou fazer massagens em vocês, massagem do estilo xavante". E isso gerou toda uma questão, do toque, da relação homem- mulher, eu poderia falar sobre isso também, eu escrevi um texto sobre isso. Você leu?

Thaís: Eu li.

Prof. Artur Matuck: Namoro em xavante que eu dei o nome. 
Edson: Tem a questão do sonho, que é importante também não é? Que toda essa ambientação era para a pessoa sonhar e no dia seguinte contar o sonho. Lembra disso? (pausa 05:32)

Edson: Estávamos falando sobre o sonho xavante. O xavante tem essa coisa do sonho performático, em que as pessoas teriam o sonho e tentariam interpretar esse sonho de uma forma performática, bem dentro da proposta do Projeto Perforum.

Prof. Artur Matuck: Por que? Por causa das performances?

Edson : Por causa das performances e pela recuperação da memória também, não é?

Thaís: Isso foi uma proposta do Hiparidi, do sonho?

Edson: É. Na verdade é uma tradição xavante. Que o sonho tem muito valor para eles.

Prof. Artur Matuck: Isso surgiu durante a oficina.

Thaís: Entendi.

Prof. Artur Matuck: A gente fez um primeiro encontro no sitio da Edméia Jafet, e dai... eu não sei se esse encontro foi iniciativa do Perforum ou foi uma iniciativa da Edméia que a gente foi convidada a participar, isso eu já não lembro.

Edson: É, o que foi realmente iniciativa do Perforum foi o Workshop que aconteceu no sítio da Paula.

Prof. Artur Matuck: Isso. A Paula Perissinoto, depois que a gente participou dessa oficina, desse encontro no sitio da Edméia, e que a gente sei lá, as pessoas se conheceram, formou um tipo de um grupo de pessoas interessadas em conhecer a cultura xavante através do Hiparidi, a gente conversou com a Paula e com outras 
pessoas, que a gente queria fazer uma oficina do Perforum sobre a cultura xavante e que a gente iria gravar, documentar, e iria ter uma série de trabalhos e a Paula ofereceu o sitio dela, que agora também não vou lembrar o nome da cidade, isso da para recuperar com a Paula, e esse foi um fim de semana mais intenso, acho que foi duas noites, sexta, sábado e domingo, e tiveram vários carros. Eu lembro que uma pessoa que participou nesse sitio da Paula foi o Cesar.

Edson: O Cesar, também o Coutinho do Mac.

Prof. Artur Matuck: O Silvio Coutinho, Teresa Labarrére, Beatriz Bianco e a Paula Perissinoto e o marido dela que chama Ramiro. Eles também estavam. E eu lembro assim que teve cenas assim, teve uma fogueira, teve danças em volta da fogueira, teve também uma questão de namoro interativo entre homens e mulheres, ficavam os homens de um lado as mulheres do outro e era uma brincadeira que ele sugeria das pessoas se aproximarem e mexerem nos cabelos. Era uma coisa assim bem poética, bem legal, interessante.

Edson: A ideia era a gente aprender um pouco da cultura deles. Trocar cultura, não era isso? Aprender um pouco da cultura deles, enquanto eles aprendiam a nossa. Teve também a pintura corporal, não sei se tem fotos sobre isso.

Prof. Artur Matuck: Não lembro. Teve pintura corporal? No rosto e no corpo?

Edson: Teve sim. Quem ensinou não foi o Hipa, foi aquele sobrinho dele Uahú.

Prof. Artur Matuck: Então, o Uhaú era um artista, ele fazia estórias em quadrinhos e o Edson está lembrando, que o Uahú que ensinou a pintura corporal. Então para nós não foi vídeo conferência a distancia, mas foi encontro de culturas numa ocasião planejada para isso, num sitio no interior de São Paulo e acho que foram umas 20 pessoas. Foi bem interessante, foi uma iniciativa bem rica. Só que no final, surgiu um certo conflito também, que eu expressei nesse texto Namoro Xavante, e o que esse conflito me ensinou de algum modo, eu acho assim que toda concepção do Projeto Perforum era uma concepção idealista e esse encontro de culturas ia resultar assim em algo utópico, que as pessoas iam se amar, se encontrar, e se 
entender, que a nossa cultura iria se entender perfeitamente com a cultura indígena brasileira, acho que tinha na minha mente, que eu tentava trazer, vamos fazer esse evento, vamos congregar pessoas, era essa utopia do encontro e na verdade essa utopia não se realizou ou se realizou parcialmente, porque teve essa coisa, eu lembro que eu estava namorando com a Cristina, a gente estava começando poucos anos de namoro e eu lembro de ver a Cristina mexendo no cabelo do Ramiro. Podemos passar para outra pergunta, mas depois temos que voltar um pouco a essa questão.

Thaís: Vocês tentaram algum tipo de financiamento na época, para o evento?

Prof. Artur Matuck: A gente sempre tenta financiamento. Eu acho que não teve financiamento nenhum. Eu acho que teve colaboração, apoio assim, por exemplo, da Biblioteca da Faculdade de Economia e Administração da USP, da FEA, que franqueou o uso da sala de vídeo conferência. Eu acho que a gente nunca teve apoio financeiro, a gente nunca recebeu nada. Só teve assim, colaboração, assim, a Yara conseguiu na UDESC, a Paula Perissinoto que ofereceu o sitio, a FEA que ofereceu a sala de vídeo conferência.

Thaís: $E$ dos eventos realizados, quais vocês acham que foram os mais bem sucedidos?

Prof. Artur Matuck: Eu acho que esse encontro, até numa área meio rural assim, eu acho que foi muito bem sucedido e agora que eu estou lembrando, com a participação do Edson aqui, está me reavivando a memória, eu acho que foi bem sucedido, apesar de ter vivenciado essa questão do conflito, eu cheguei à conclusão que o conflito faz parte da comunicação. Entendeu? Achei que o meu idealismo era exagerado, que eu acho que na comunicação natural entre as pessoas, as culturas, o conflito para mim é um fenômeno natural, assim, difícil de ser evitado e através dele a gente pode aprender. Seria um aprendizado.

Edson: Mas se houvesse um apoio financeiro mesmo, poderia ter ido mais longe. Esses seus planos de atingir Portugal, atingir a África, eu acho que num sentido foi comprometido por falta de financiamento. 
Prof. Artur Matuck: É. Eu acho que por falta de financiamento, por falta de uma tecnologia mais acessível, não é? Como hoje tem o Skype, na época não tinha. E eu não lembrava, a gente procurou contato com a África também, não é?

Edson: Isso. Até teve algumas participações, não é?

Prof. Artur Matuck: Teve?

Thaís: Na Europa teve?

Prof. Artur Matuck: Teve uma participação bem legal, de uma negra que trabalha na prefeitura, chamada Elisabete. Acho que ela chama Elisabete Pinto. E ela é uma líder, não sei se ela é a criadora ou fundadora ou ela participa de uma ONG, não sei como é o nome da ONG. Mas era uma ONG que eu achei extremamente interessante o trabalho dela, recuperação de meninas jovens, na cidade de São Paulo, para que as meninas não seguissem o caminho da prostituição, era um apoio para meninas jovens, meninas negras. Eu lembro que a Elizabete Pinto topou participar, ela como negra, como líder negra, e trouxe a experiências dela, e uma das conferencias que eu achei bem legal foi um... se eu bem me lembro, a gente teria que ver a documentação em vídeo, foi um diálogo entre a Elizabete e uma artista de Florianópolis convidada pela Yara, que era uma artista que trabalhava com a questão do obeso, da mulher gorda. Então elas trocaram experiências, imagens, o Perforum teve vários desses momentos de diálogos a distancia. Entre artistas ou entre indivíduos como a Elisabete não era uma artista, era mais uma líder, assim uma ativista, para a mulher negra, mas ela não era uma artista. Então o Perforum proporcionou esse tipo de diálogo entre artistas e indivíduos, entre lideres e artistas.

Edson: Eu lembro que houve também um índio de Santa Catarina... é isso?

Prof. Artur Matuck: Não era um cafuzo?

Edson: Isso. O cacique Cafuzo. 
Prof. Artur Matuck: O Cafuzo era um cacique que era a mistura do negro com índio. E esse senhor foi encontrado pela Yara, no interior de Florianópolis, no interior do estado de Santa Catarina, veio até Florianópolis para participar de uma conferência com o Hiparidi, e essa conferência aconteceu aqui na Faculdade de Economia e Administração. Eu vi um fragmento da documentação dessa conferência recentemente, e uma coisa que me chamou a atenção e que eu acho que era uma certa inocência que a gente tinha na época, a gente tinha essa ideia de inovar a linguagem, recriar a linguagem da vídeo conferência e tudo o mais, e a gente trabalhava por algum motivo que eu não vou lembrar exatamente qual, a gente trabalhava com uma série de espelhos, e assim tinha o Hiparidi falando, o Cafuzo falando e tinha pessoas da nossa equipe com os espelhos assim atrás. Então hoje eu acho uma coisa ingênua e deslocada e seria assim a construção de uma imagem que na verdade desvia a atenção daquilo que aquela pessoa esta falando que devia ser o foco. Então isso é até uma questão critica que a gente podia elaborar melhor vendo os vídeos. Mas eu lembro que uma das experiências que o Ricardo Barreto fez era justamente com espelhos. Ele fez uma tentativa de devolver a imagem que estava chegando. Então a imagem que estava chegando de Florianópolis para São Paulo era refletida num espelho, capturada por uma câmera e enviada para Florianópolis e se tornava tipo um jogo de espelhos assim. Era uma experiência formal da vídeo conferência, e essa experiência era uma coisa que tinha até sentido, uma coisa conceitual, formal. Agora, a experiência de criar umas variações de imagens com espelhos ao lado de personagens que estariam falando da experiência cultural deles, isso hoje em dia eu acho deslocado, meio estúpido. E eu lembro que no vídeo - conferência que a gente apresentou o Hiparidi para o cacique Cafuzo e eles conversaram, e eles se disseram: "tudo bem?" e a conversa não progredia. $\mathrm{Na}$ verdade assim, foi uma falta de planejamento nosso, eu acho. A gente conseguiu realizar o encontro, mas o encontro não se desdobrou em algo relevante, o que eu acho assim que era o reflexo da nossa falta de experiência em produzir encontros através de vídeo conferência. Você lembra-se desse encontro? Você estava lá, não?

Edson: Lembro. Eu acho que teve um desdobramento. Eu mesmo depois ainda fui visitar o Hiparidi lá na aldeia dele, acho que teve um desdobramento assim, inesperado. 
Prof. Artur Matuck: A gente podia ouvir mais da experiência do Edson, a gente já trabalhou juntos em vários projetos, a gente ficou amigo, intelectuais que trabalham juntos em várias coisas e o Edson sempre apoiou meus projetos, e através do Perforum o Edson conheceu o Hiparidi e desenvolveu uma amizade particular dele com o Hiparidi, e chegou a ir à aldeia. Você tem fotos, da aldeia?

Edson: Tenho.

Prof. Artur Matuck: Essas fotos seriam interessantes para o Projeto Perforum, o que está me ocorrendo agora, sei lá, eu nunca pensei completamente nisso.

Thaís: Desdobramentos pessoais. Que todos participantes talvez tivessem algum desdobramento diferente.

Edson: É. Mesmo a Paula, acho que transformou a vida dela, ela começou a fazer muitos trabalhos na área de tecnologia e agora eles fundaram o FILE. De juntar essas pessoas, juntou ela com o Ricardo, não é? Que hoje os dois são parceiros nesse FILE.

Prof. Artur Matuck: Eles já eram próximos. Eles vieram juntos participar do Perforum, fizeram o trabalho. Mas é interessante o que o Edson está falando que ele está chamando a atenção, assim, um trabalho que se propunha a ser um encontro através da tecnologia resultou também no encontro das pessoas ao nível presencial. O Edson foi pessoalmente visitar uma tribo xavante no Mato Grosso do Sul.

Edson: No Mato Grosso.

Prof. Artur Matuck: Para mim isso é uma coisa valiosa, eu fico contente, porque é uma coisa que eu não estava contando como parte do Projeto Perforum, mas eu acho que pode ser contado. E como foi assim? Você conheceu o Hiparidi dentro do Projeto Perforum, na casa da Paula, na casa da Edéia?

Edson: Sim, foi você que me apresentou o Hiparidi, não é? $E$ depois, nessa integração eu fui me aproximando, ele me convidou e na realidade ele convidou todo 
mundo para ir à aldeia, e você não sei por que acabou não indo, não é? Foi um grupo grande, não fui só eu, tinha uma professora antropóloga da PUC, Maria Helena foi também e a gente foi para conhecer justamente, e ele levou a sério essa coisa de mostrar a cultura dele, daí estivemos lá na aldeia, participamos de rituais, passeios na natureza mostrando as plantas que eles usam e também no dia a dia ali da aldeia, a gente ficou uma semana com ele. Isso foi nesse primeiro grupo. A Edméia também esteve, mas foi numa época diferente da minha, ela foi num outro grupo. Ela também foi lá, é a Aldeia de Sangradouro, inclusive acho que teve um pessoal aqui, não é? Olha ai. É essa mesma Aldeia de Sangradouro, o Sérgio Baio, depois você pode contar o que aconteceu, mas... foi um grupo grande que esteve aqui?

Renata: Pelo menos 10. Eu não tenho certeza da quantidade exata, mas eram quatro bororos e o resto eram todos xavantes.

Edson: Pois é, e nós estivemos lá nessa Aldeia de Sangradouro em Mato Grosso, e tomamos banho de rio, fizemos tudo o que eles fazem lá. Pintamos o corpo, à noite eles se reúnem sempre naquele... parecido com o que ele fez no sitio da Paula, onde se dança, tem jogos entre as pessoas e onde os velhos falam também, é interessante, é tipo uma assembleia da aldeia. Então, foi muito longe essa amizade que eu desenvolvi com eles. Eu voltei depois outras vezes lá, sozinho. Inclusive quem foi também lá na aldeia foi a Suzana, você está esquecendo a Suzana do CCE, não é?

Prof. Artur Matuck: CCE. Suzana de Moraes, ela participou bastante do Perforum. Ela sempre colaborou, não é?

Edson: Sim, sim. Ela dá um certo apoio...

Prof. Artur Matuck: Apoio técnico.

Edson: Ela esteve lá na aldeia também, inclusive estivemos eu e ela só, livre desse grupo maior. Aliás, esse grupo maior também teve atritos. 
Prof. Artur Matuck: É mesmo.

Edson: É igual você fala mesmo, os atritos fazem parte.

Prof. Artur Matuck: É, a conclusão a que eu cheguei é que essa ideia utópica das diferentes culturas se integrar e tudo maravilhoso e a redescoberta de um Brasil e de repente, não é assim, que as pessoas tem conflitos, as pessoas tem ímpetos, tem...

Edson: É isso mesmo.

Prof. Artur Matuck: O que eu estava lembrando, o Edson fez amizade com o Hiparidi e a Cristina minha esposa, fez uma amizade com o Uahú.

Edson: É verdade.

Prof. Artur Matuck: Que ela gosta muito de artes plásticas e o Uahú era um excelente desenhista, um artista, ele fazia estórias em quadrinhos das narrativas da tribo e contavam estórias da tribo para a gente. Uma história que eu fiquei assim muito entusiasmado, maravilhado é a história da Aldeia Abelhinha. Isso eu acho que valia muito a pena incluir no trabalho, porque eu acho que é uma estória muito fantástica. Porque é o seguinte, o Hiparidi e outros líderes viviam numa aldeia, que estava sofrendo uma influencia muito grande.

Edson: Essa é a Aldeia de Sangradouro, tem todos esses problemas que vocês acho que documentaram ai, de alcoolismo e aquelas coisas, que é uma aldeia muito grande, então, começa a ter problemas, e o pai dele na realidade, que é um grande líder, curandeiro também, ele falou: "não, não vamos ficar mais aqui". Ele reuniu a família e foi fundar outra aldeia.

Prof. Artur Matuck: Que chamou Abelhinha.

Edson: Isso.

Prof. Artur Matuck: Então, daí eu achei interessante isso, porque assim, no século 
$X X I$ ou foi fundada no final do século $X X$, não lembro agora, isso precisaria pesquisar, mas eu sei assim, os lideres xavantes se reuniram e falaram assim: "Nós vamos criar uma outra aldeia. Nós vamos fundar uma aldeia." E foram e fundaram segundo Hiparidi me disse, dentro da tradição xavante. É ao lado de um rio, que é uma fonte de água e tem todo um desenho da aldeia e tudo e realmente fundaram, para se separar e evitar a influencia do homem branco, do ocidental, entendeu? Então, eu achei uma coisa assim, uma narrativa épica. É uma questão assim, bem interessante.

Edson: É, também, porque Sangradouro, essa aldeia apesar e ter problemas de alcoolismo, ela é ligada à igreja, aos salesianos.

Prof. Artur Matuck: Exatamente. E que parece que eles não queriam que os xavantes falassem a própria língua deles.

Edson: Não sei se é exatamente isso, mas vai perdendo a tradição...

Prof. Artur Matuck: Identidade própria.

Edson: Porque eles foram educados pelos salesianos. O próprio Hiparidi foi, frequentou a escola dos salesianos, Mas ai eles queriam se distanciar de toda essa cultura, não é? Desse peso cultural. Não que houvesse pressão por parte dos salesianos, tanto que eles tiveram toda liberdade de fundar outra aldeia, porque a terra indígena é grande a terra que eles vivem lá, é em Mato Grosso e é uma terra bastante grande. E estava muito concentrado numa única aldeia.

Prof. Artur Matuck: Ah, então tinha também uma coisa geopolítica.

Edson: É.

Prof. Artur Matuck: Eu lembro que uma vez a gente recebeu um telefonema, do Hiparidi, da família dele, dos amigos dele, e falando assim: "olha, hoje à noite a gente queria que vocês viessem aqui" era na Rua Fábio, na Lapa, "que é o aniversário do Hiparidi e a gente queria que vocês viessem visitar a gente tudo, não 
é?" E daí eu e a Cristina fomos, e daí chegou lá "Parabéns Hiparidi, não sei o quê", e ele falou assim: "não é meu aniversário". "Não é aniversário do Hiparidi. É que a gente sabe que se a gente chama vocês para discutir questões políticas, sociais, vocês normalmente não percebem, mas se a gente fala que é um aniversário vocês se sentem obrigados a vir, então a gente falou que era aniversário para você ver o que está acontecendo na aldeia, que é uma coisa importante" Daí abriram uma fotografia aérea e falou assim: "essa é a área da aldeia, e está sendo invadida pelos plantadores de soja". Então, o verdadeiro motivo da reunião era: "olha, a gente precisa que vocês colaborem na nossa luta pela nossa terra, pela nossa autonomia como tribo, mas por isso que a gente convidou vocês aqui não foi por causa do aniversário." Aliás, os xavantes nem comemoram aniversário.

Thaís: E teve algum evento que você gostaria de ter realizado, mas que não deu certo por algum motivo?

Prof. Artur Matuck: Bom, teve esses que a gente citou não é? De ter contato com... Thaís: Com os outros países.

Prof. Artur Matuck: Países da África, alguns de língua portuguesa pelo que eu lembro e também com Portugal, a gente não conseguiu realizar nenhum desses contatos, e nem mesmo com indivíduos portugueses ou africanos. Teve um trabalho que eu achei excepcional de perfomance, do Celso Fonseca, que na época eu acho que ele já era meu orientando ou era meu aluno da pós-graduação e ele é um artista negro e ele fez um trabalho que eu acho excepcional e eu espero que ainda tenha essa gravação, em que ele escreveu uma carta, não é? Mas ele escreveu uma carta assim, num papel muito grande, de uma dimensão muito grande. Então, que ele entrava na carta, ele pisava na carta enquanto ele escrevia. Tinha uma escala maior do que uma folha de papel. Uma escala de uma sala. Então, esse trabalho eu fiquei muito contente dele ter realizado esse trabalho. Eu acho que tem uma relação. Isso precisaria até entrevistá-lo, incluir o vídeo, documentar o vídeo. Outra pessoa que poderia ser entrevistada é o próprio Hiparidi, ou pessoalmente ou através do skype, não sei, acho que ele mora em Brasília, não é?

Edson: Ele está na aldeia agora, mas ele pode... está no Facebook também, agora 
a Naira também participou, não?

Prof. Artur Matuck: A Naira Ciotti, não sei. Ela sempre participa dos projetos, mas não lembro se participou não...

Edson: E aquela Madalena, que era cantora?

Prof. Artur Matuck: Madalena Bernardes?

Edson: Eu acho que também ela fez alguma coisa.

Prof. Artur Matuck: Não lembro. Agora, a Yara, todos os projetos que a gente tinha em São Paulo, a gente se comunicava com a Yara, a Yara chegou a reunir muitas pessoas, artistas e estudantes de arte da UDESC, e fizeram muitas performances. Eu lembro a ocasião e depois, montaram verdadeiros espetáculos, de dança, circo, canto, artes plásticas, eram assim verdadeiros espetáculos, e a nossa proposta, que hoje eu também acho que era uma proposta ingênua, é essa proposta da interatividade. Então, tinha que ter interatividade, isso eu acho uma questão um pouco ingênua hoje.

Edson: É a tele presença, não era isso?

Prof. Artur Matuck: Era telepresença com interatividade, e tinha toda uma ideia de que "nós vamos mandar alguma coisa para vocês e vocês respondem a nossa proposta e depois vocês mandam alguma coisa para nós e nós respondemos". Então, em alguns momentos essa necessidade de interatividade acabou gerando conflito também, e eu vi esses dias, há uma semana o vídeo de uma vídeo conferência, basicamente eu em São Paulo com mais uma ou duas pessoas, não lembro quem eram exatamente e a Yara com outras pessoas, mas era basicamente eu e a Yara. E a minha proposta era assim: "eu vou ler e escrever um texto", e eu acho que tinha imagens bonitas assim, eu até estava vendo as imagens e eu fiquei bem interessado nas imagens, que é um texto que eu imprimi o texto e daí eu pus o papel vegetal em cima do texto, e eu me propunha a ler e escrever em cima do texto, escrever num papel manteiga ou papel vegetal. Então, a pressão do lápis faz 
o texto de baixo aparecer e desaparecer, porque quando a pressão do lápis desaparece o papel vegetal sobre e o texto desaparece, mas quando ele vai ser escrito ele recupera, a imagem de baixo é recuperada. Então, a proposta desse evento... se não me engano o nome desse evento era: "Lapsus Calami", que é uma palavra que eu descobri num texto do Derrida. Que é o lapso da escrita, porque o lapso da fala é uma coisa mais conhecida, mas existiria o lapso da escrita. Então, eu li há alguns anos atrás sobre um trabalho de vídeo de um artista inglês que ele divida a tela de televisão no meio e que de um lado ele lê um texto e do outro lado ele escreve um outro texto. E ele tenta ler um texto enquanto ele esta escrevendo um outro texto. Então, isso seria uma sobrecarga de informação para o cérebro e faria com que ele errasse. Ele escreveria errado ou leria errado. E daí eu tentei fazer uma obra similar, e eu me propus a ler e escrever um texto que eu tinha escrito, enquanto a Yara iria conversar comigo, interagir comigo e iria verificar se eu iria errar em algum momento. Então, a gente começou esse trabalho, eu comecei lendo e depois de duas frases a Yara me interrompe e fala assim: "eu acho que não esta dando certo. A gente devia mudar as regras, devia fazer um outro trabalho, um pouco diferente". Mas não sei se por teimosia minha, daí eu falei não. Eu vou pegar esse texto, foi o combinado que eu iria ler esse texto, e eu vou ler até o fim. Mas foi extremamente difícil eu continuar a leitura, a toda hora ela falava assim: "Não. Eu acho que não está funcionando, você não está ouvindo o que eu digo". Então, assim, foi um conflito bem... e esse conflito está gravado. E ele pode ser estudado e presenciado.

Edson: Um tele conflito!

Prof. Artur Matuck: É. Um teleconflito. Eu acho que daí já não é um conflito entre o branco e o índio, entre o ocidental e o indígena, eu acho que é um conflito entre o homem e a mulher, eu acho que existe esse conflito, é um conflito entre dois artistas, entre dois criadores, entre dois escritores. Então... eu lembro que ela falou uma frase: "você quer manter o controle, o seu psiquismo não permite que você erre, que você ouça o que eu estou dizendo." Então, assim, tinha toda uma questão assim de... a busca da interatividade mas que entrava em conflito, por exemplo, com eu vou ler um texto. Então, esse você não estava, não é? Teve um também que não sei se a gente vai achar, uma vídeo conferência que foi muitíssimo interessante eu 
acho, que foi com a Tereza Labarrére. A Tereza Labarrére estava entrando na pós graduação da USP, então, ela veio me procurar por indicação do Arlindo Machado, e a gente ficou amigo mas eu nunca fui orientador dela, ela foi orientada pelo Arlindo Machado, se não me engano ela terminou o mestrado dela assim. Mas na época que a gente se aproximou eu convidei ela a participar do Projeto Perforum e ela aceitou e teve um dia que a gente marcou uma vídeo conferência com a Yara, e essa vídeo conferência iria acontecer na Anhembi Morumbi, que foi franqueado por nós o equipamento deles, pela Carmem.

Edson: Carmem Maia.

Prof. Artur Matuck: Carmem Maia. Que se não me engano era filha de um dos donos da Anhembi Morumbi, e ela falou "não pode usar nosso equipamento", e a gente foi lá no Brás, na unidade deles no Brás, e daí eu passei na casa da Teresa e falei: "vamos para a vídeo conferência" e ela falou: "eu não vou poder ir", "mas porque" e ela falou "eu não tenho com quem deixar o Natan", que era o filho dela, que na época acho que tinha uns 5 anos. Daí eu falei, não, trás o menino. $\mathrm{E}$ o menino adorou. E ele participou do começo ao fim. Eu não sei e a gente tem essa gravação ou não, ai eu já acho assim, que entrou um elemento do não planejado, do inusitado, que assim em nenhum momento a gente imaginou: "vamos colocar uma criança numa vídeo conferência?" Mas ele foi o que mais aproveitou. Ele conversou, discutiu, falou e foi novamente com a Yara. E nesse dia também teve um novo conflito com a Yara. Que foi um conflito que eu acho assim... que assim, assumiu proporções mais graves ainda, porque nesse do Lapsus Calami, foi uma discussão constante sobre as regras do evento, "devemos mudar as regras, não devemos", e eu falava não vou ler o texto até o fim, alguma coisa assim, foi uma discussão, mas nesse não, nesse houve um ressentimento, uma briga, e um dos motivos da briga é assim, a Yara mandou um trabalho e ela queria uma resposta nossa e o sistema começou a falhar. Quer dizer, o sistema falhou a transmissão. A gente não conseguia transmitir nada para eles. A gente conseguia ouvir o que eles diziam, mas a gente não conseguia transmitir nada para eles. $E$ depois de um tempo que o sistema voltou a funcionar, a Yara estava extremamente nervosa. Estava assim agredida, perturbada, digamos ofendida. E eu não entendia o porquê de tudo, e eu não sei se naquele momento ou depois ela entendeu que a nossa resposta à 
proposta dela era não responder nada. Era não mandar nada e ficar em absoluto silêncio. Não mandar nenhuma imagem e ficar quieto. Que era o que a gente estava fazendo, mas não de propósito, o sistema falhou. Mas ela encarou o que estava acontecendo que era uma interrupção do sistema como a nossa intenção, a nossa resposta era não fazer nada e isso causou um ressentimento bem grande. Então, eu acho interessante isso também, porque assim, a comunicação a distancia com a tecnologia ela tem falhas, e como essas falhas são interpretadas. Como uma gravação de vídeo acho que tem falhas, não é? Vamos pegar uma garrafa d'água e tem um som, não é? Pode-se pensar "não, ele fez de propósito", pode ser interpretada de mil maneiras. Então, como a falha tecnológica é interpretada eu acho bem interessante.

Edson: O Donasci, que fez umas coisas interessantes também, não é? Consegue lembrar alguma coisa? Eu lembro que ele queria colocar essa imagem na vídeocriatura.

Prof. Artur Matuck: Na video criatura. Na verdade ele fez isso no Intercities, mas eu acho que no Perforum ele acabou não participando. Eu não lembro. Eu não sei se o Otávio participou de alguma das vídeo conferências.

Edson: Eu lembro dele aqui na FEA, agora não lembro exatamente o que ele fez. Acho que tem eu buscar na documentação eu lembro dele na FEA.

Prof. Artur Matuck: Uma pessoa que podia ser entrevistada é o Cesar. É uma pessoa que se não me engano na época era meu orientando de pós- graduação, na área de Artes Plásticas.

Edson: O Donasci, se não me engano, eu acho que ele fez o trabalho com você acho que foi sobre os brinquedos. Lembra os brinquedos? De lata?

Prof. Artur Matuck: Olha, os brinquedos de lata a gente fez uma experiência lá na Anhembi Morumbi, e eu lembro que estava eu e você, mas acho que o Otávio não estava. Isso tem o vídeo, com certeza eu tenho essa gravação. Que na verdade assim, não teve muita interatividade, mas foram esses brinquedos de corda, de lata, 
que a gente dava corda nos brinquedos e amarrava umas canetas coloridas e eles saiam desenhando. E na época eu estava simplesmente maravilhado com a possibilidade dos brinquedos de lata fazerem arte por si mesmos. E a gente colocou um espelho inclinado e eles vinham se aproximando e a imagem deles se refletia e a gente transmitiu esses trabalhos se não me engano para Florianópolis, todas as transmissões foram para Florianópolis.

Edson: É, não tinha outro ponto de interatividade. Foi realmente o único.

Thaís: E havia uma preocupação com a documentação dos eventos?

Prof. Artur Matuck: Na verdade havia uma grande preocupação, isso era constante e tinha o propósito de troca de fitas entre São Paulo e Florianópolis, entre o Perforum São Paulo e o Perforum Desterro, que chegou a acontecer uma ou outra vez. E na verdade tinha um planejamento de documentação que tornava as coisas extremamente complexas, tornava a tarefa de documentar extremamente complexa, porque a gente imaginava o seguinte, a gente tinha que gravar o som e a imagem que estivessem chegando em São Paulo, por exemplo, ai já seria uma fita, e eram fitas VHS, o som e a imagem que estivesse vindo de Florianópolis para São Paulo iria ser uma fita, a outra fita seria o som e a imagem que nós estávamos emitindo de São Paulo para Florianópolis, seria uma segunda fita, e esses eventos duravam assim, duas horas, que era o tamanho da fita, era basicamente era mais ou menos isso. $\mathrm{E}$ tinha uma terceira fita, que ficava numa câmera com um câmera man ao vivo no espaço que a vídeo conferência estava acontecendo. Então, tinha uma terceira fita, que seria a documentação do que estava acontecendo no espaço. Então, eram três fitas de cada lado. Em São Paulo que estava gerando três fitas e o mesmo esquema de documentação estaria acontecendo em Florianópolis mais três fitas. Eu acho que na verdade nem todas as vídeo conferência geraram seis fitas. A nossa ideia era fazer as fitas São Paulo chegarem a Florianópolis e as de Florianópolis chegarem em São Paulo e isso também não aconteceu, e eu tinha contato com a Yara, você vai mandar a fita ou não vai mandar a fita, um pouco do conflito humano surgia e interferia nesse processo, existia se bem me lembro: " mas você vai mandar as suas? Se você não mandar a sua não vou mandar a minha", tinha umas questões assim. Na verdade o que sobrou foram poucas documentações, eu acho que a 
maioria das documentações são de câmeras do espaço, as fitas que documentariam o que chegou e o que ia, não sei, não existiram.

Thaís: Comparando com outras comemorações realizadas no ano 2000, qual é a principal diferença do Perforum?

Prof. Artur Matuck: Viu? Acho que a ideia era contestar os próprios 500 anos. Essa noção mítica de que Portugal descobriu o Brasil. De que o Brasil só existe por causa de Portugal. É como o beijo que o príncipe dá para a princesa, não é? Eu acho isso interessante, essa estória de que nos contos de fadas a mulher só começa a existir quando o homem surge. De outro modo, a mulher esta num sono eterno, ela não tem identidade, não tem existência, é o homem que faz o toque mágico e a mulher começa a existir. Então, não sei, existe uma mitologia de que o Brasil existe por causa de Portugal. De que Portugal descobriu o Brasil, não é? Então acho que tinha essa ideia, que era uma ideia utópica também, de autonomia do Brasil, e recentemente eu li sobre essa questão, do Oswald de Andrade, não é? Ele vai refundar o Brasil através da deglutição do Bispo Sardinha, não é? Eu acho uma coisa interessantíssima o que ele faz, ele funda um movimento artístico cultural, intelectual, nacionalista, chamado Antropofagia, ele fala que o Brasil na verdade se inicia quando os índios Caetés deglutem um bispo português, e recentemente eu estava estudando isso e eu descobri que essa estória pode ser simplesmente uma farsa, que existem depoimentos que dizem que quem matou o bispo sardinha foram os próprios portugueses, e eles alem de matar o bispo português, eles resolveram culpar os índios brasileiros, que não tinham nada a ver com a estória, porque culpando os índios brasileiros, os chamados Caetés do Ceará, poderia haver uma razão para que os portugueses tomassem conta da terra dos índios Caetés. Porque eles seriam considerados como índios assassinos, antropófagos. Então, haveria uma razão para que eles fossem destituídos de sua propriedade. Isso daí assim, não sei o que o Oswald de Andrade pensaria disso, não é? Que a deglutição do Bispo Sardinha seria uma farsa. Mas acho que mantém esse sentido simbólico, aliás, não sei porquê a gente não usou isso no Projeto Perforum , a gente podia fazer a ultima pergunta do novo Perforum acho que devia incluir isso, a não deglutição do Bispo Sardinha pelos índios Caetés. Agora, eu não sei, acho que a principal diferença seria essa de alar: "vamos ouvir o índio, vamos ouvir o negro e não só o branco. A nação 
brasileira tem essa s três etnias que se cruzam e que constrói o Brasil que a gente conhece, e porque os 500 anos da descoberta do Brasil pelos portugueses? Porque não a descoberta do Brasil pelos índios, pelos negros? Então essa era a ideia, e essa era a principal diferença. Não sei, o que você acha Edson?

Edson: É, eu acho que se confirmou, não é? Porque as comemorações oficiais foram um fracasso. Teve aquele conflito que houve em Porto Seguro, com os índios que queriam se manifestar ai fecharam a cidade, os índios não conseguiam chegar e houve conflito na estrada. Quer dizer, se confirmou essa discriminação, quer dizer, não chamaram para a festa os índios, no caso, não é?

Prof. Artur Matuck: Eu acho que esse evento faz parte do Projeto Perforum, de uma maneira mágica, conceitual, e ousada.

Edson: É um contra evento.

Prof. Artur Matuck: É, é um contra evento. Eu acho que ele faz parte da estória do Projeto Perforum, e devia ser incorporado na memória do Projeto Perforum.

Edson: Sim, porque você fala que muitas coisas não deram certo no Perforum, teve conflito, mas no evento deles também teve vários conflitos, teve aquela questão da caravela também, que eles pensavam fazer uma caravela que eu não sei se vinha de Portugal para cá ou se ia daqui para lá, mas no fim os engenheiros não conseguiram fazer a caravela navegar.

Prof. Artur Matuck: Quer dizer... 500 anos atrás era possível?

Edson: E ai você vê, era um conflito. Essas pessoas ficaram bem mal, não é?

Prof. Artur Matuck: Para quem está numa escola de comunicação, no departamento de relações públicas, são estórias fantásticas. Que eu acho que nessa questão, o que a federação, o Brasil, o que eles tentam comemorar? Porque é importante a comemoração dos 500 anos do Brasil? De que maneira e o que essa comemoração quer mostrar? 
Edson: É, eu acho que é importante porque agora já está se falando da comemoração de 22, não é?

Prof. Artur Matuck: Isso.

Edson: Então, é bom que se incorpore esses erros, essas experiências que houve agora, para não se repetir. Porque em 22, em 1922 houve coisas fantásticas como a semana de 22, quer dizer, espero que não seja outro fracasso.

Thaís: $\mathrm{E}$ as ideias futuras, quais foram os principais desdobramentos do Projeto Perforum?

Prof. Artur Matuck: Pois é, a gente falou dos desdobramentos hoje, em outras questões, não é? Quais foram os desdobramentos.

Thaís: Em outros projetos talvez?

Edson: Deu uma tese, não é? A Yara escreveu uma tese sobre telepresença.

Prof. Artur Matuck: A Yara se envolveu bastante e desenvolveu uma tese de doutorado sobre tele arte, e ela se aprofundou bastante no tema e lançou um livro. E esse foi um desdobramento.

Edson: E o outro desdobramento é a dissertação da Thaís.

Prof. Artur Matuck: É, outro desdobramento foram essas relações humanas que surgiram, a gente lembro do Edson com o Hiparidi, a Edméia e a Cristina Jansen com o Uahú, que desenvolveram uma amizade assim até bem bonita. A estória do Uahú também é muito interessante. Se a gente pudesse localizá-lo, porque os xavantes eles vem, muitos deles e o Edson pode falar depois um pouco disso, eles vem da aldeia para São Paulo, para defender a aldeia, para trazer a cultura xavante, para fortificar a cultura xavante, só que alguns deles, se desligam da cultura xavante. Como o Uahú ele acabou se casando com uma ocidental, uma branca. E isso foi criticado pelo tio dele, que é o Hiparidi, não sei se pó outros lideres também. 
Edson: Mas eles conseguiram recuperá-lo.

Prof. Artur Matuck: Conseguiram?

Edson: Conseguiram. Ele voltou para a aldeia. Casou na aldeia, tem filhos. Uahú.

Prof. Artur Matuck: É?

Edson: Mas abandonou a arte. Abandonou. É professor eu acho, na aldeia.

Prof. Artur Matuck: Mas não de arte?

Edson: Não.

Prof. Artur Matuck: Então, esse movimento eu acho interessante também, assim essa questão da preservação da cultura em contato com o que eles vem fazer aqui, que é muitas vezes uma questão política, não é? Eles querem que a gente se aproxime da cultura xavante. Eu fiquei bem impressionado quando eu fui a casa dele, que ele mostrou a aerofotogrametria da área que eles ocupam, e tinha outros professores da USP da área de geografia...

Edson: Professor Umbelino.

Prof. Artur Matuck: Umbelino?

Edson: Da FFLCH.

Renata: Thais, veja quais perguntas você tem para fazer se vale a pena interferir, porque está um caos isso aqui agora.

Thaís: Só mais uma, fora a ultima, tem mais alguma ideia de pergunta?

Prof. Artur Matuck: então vamos pedir um pouco de silêncio. 
Renata: Eu posso tentar de novo agora, mas acho que não vai fazer diferença.

Prof. Artur Matuck: Então faz a pergunta.

Thaís: Se fosse realizar uma nova edição do Projeto Perforum hoje, como seria?

Prof. Artur Matuck: Uma sugestão seria planejar alguma coisa para 2022. E a gente estava falando da deglutição do Bispo Sardinha, que talvez tenha sido uma farsa, uma estória criada e que foi acreditada e durante anos e anos foi história oficial, que os índios brasileiros eram ferozes antropófagos e que tinham deglutido ferozmente um bispo, não sei se cru ou cozido, não é? Então, eu estava pensando assim, eu acabei de ler sobre essa questão da farsa, que talvez seja uma farsa, e é uma farsa cruel, uma farsa criada para acusar os índios de assassinato para que eles possam ser prejudicados e destituídos de suas terras e também de uma identidade. Então, o artigo que eu escrevi que é sobre a desescritura, que espero dê tudo certo, vai ser publicado nos EUA, ele começa descrevendo a desescritura, que foi um processo textual que eu criei nos EUA em 94, 95, e daí eu vou falando assim, para mim durante muitos anos esse seria um projeto meramente técnico que é uma questão de criar a escrita digital, mas conforme os anos foram passando e eu me lembrando, o que me influenciava e tudo, eu percebi que não é uma questão meramente técnica, é uma questão pessoal, eu tenho interesse em desestruturar a língua inglesa, ou desestruturar as línguas em si mesmas, tinha toda uma persona artística que eu queria assumir, que era essa persona que resistia à cultura estrangeira, que resistia, eu estou aprendendo na língua inglesa, eu vou me expressar na língua inglesa, mas eu contesto esse absolutismo da língua inglesa, o projeto da desescritura é um projeto de destruição da língua inglesa através do computador, através da tecnologia, de desestruturar as palavras. De recriar palavras através de uma programação computacional. Então esse nome desescritura, e daí eu fui falando da questão ideológica e eu cheguei no manifesto antropológico do Oswald de Andrade, que coloca a refundação do Brasil e tudo o mais. E daí conforme eu fui pesquisando esse movimento antropofágico eu me deparei com isso texto que fala que talvez tenha sido uma farsa. Então, tem autores que falam que isso foi uma farsa, não foi verdade, não foram os índios que deglutiram o Bispo 
Sardinha. Durante algumas semanas eu ficava procurando a finalização desse artigo, e agora que eu acho que eu cheguei na finalização desse artigo, eu criei um termo que é a deistorização, quer dizer o que criou um paralelo com a desescritura. Então para mim não basta transformar a língua é preciso transformar a história. A história oficial, entendeu? Então a investigação histórica, ela pode partir desse princípio que eu acho que tem tudo a ver com Perforum, que é ouvir as vozes minoritárias, as etnias sem poder, as culturas que foram deslocadas, que foram destruídas ou que houve uma tentativa, e elas eventualmente poderiam ressurgir. Então, na verdade eu acho assim, um novo Projeto Perforum seria essa ideia de utilizar as tecnologias mais recentes para esses propósitos de deistorização, de reescrever a história, de resisitir à história dominante. Porque eu acho que era um projeto do Perforum de usar as tecnologias mais atuais e de uma maneira que resistisse ao poder da comunicação, que é um poder de comunicação exercido pelas tecnologias, quer dizer era uma subversão do uso das tecnologias, eu acho assim a sugestão do Edson, que eu acho que partiu dele até, de realizar um novo projeto em 2022 ou antes, não é? Pode começar antes, seria ótimo.

Edson: Fazer igual o aniversário do Hiparidi, faz de conta que já é 22, não é?

Prof. Artur Matuck: Essa é uma boa ideia também, fazer como no aniversário do Hiparidi.

Edson: A gente não sabe se vai estar vivo em 2022, já faz agora a comemoração.

Prof. Artur Matuck: Subverte as datas, não é?

Edson: Eu acho que tem a ver, porque eu acho que o Milton Santos, que a Thaís está estudando para a tese dela, para a dissertação dela, vai virar uma tese no fim das contas, é que não basta uma nova tecnologia, precisa uma nova filosofia.

Thais: Por uma outra globalização.

Edson: Por uma outra globalização falando isso, que tem que haver uma nova filosofia. 
Prof. Artur Matuck: E você que esta se interessando cada vez mais por psicologia e psicanálise, eu acho que toda essa história cultural das etnias tem muito haver com psicanálise e psicologia. Com a questão da identidade, da pessoa que constrói uma identidade numa cultura, entendeu? Como eu, por exemplo, eu passei por um processo de exílio, eu me propus a aprender a língua inglesa, enquanto eu morava no Brasil, ai eu viajei para os EUA aprendi mais o inglês, e daí comecei a escrever em inglês, e mais recentemente eu já tentei também escrever em Frances e eu estou nesse processo de refletir sobre o meu próprio processo criativo passando por outras línguas, porque eu me interesso por outras línguas? Porque eu me interessei pelo esperanto? E eu estou lendo agora esse livro que se chama: Pensar entre línguas, que é uma biografia do Vilém Flusser. E o Vilém Flusser, um filósofo um dos principais dos últimos tempos, das ultimas décadas que nasceu na república tcheca, na ex Tchecoslováquia e morou durante 20 anos em São Paulo e quando ele chegou em São Paulo ele aprendeu o português e começou a escrever em português e desenvolveu um método de criação filosófica, da auto-tradução, ele escrevia numa língua traduzia para outras várias línguas e depois voltava a tradução para a língua original. Isso na tentativa do pensamento dele florescer de um modo inusitado. Eu acho fantástico essa questão da identidade cultural e como esse processo se reflete na identidade individual. $E$ no Brasil eu acho que isso é importantíssimo. Porque o Brasil é um pais colonizado. E quando o Brasil vai construir uma cultura com uma identidade própria, entendeu? Não sei se isso já esta acontecendo ou não. Mas o próprio Milton santos já é um exemplo excepcional. Um negro que se transformou num geógrafo, sei lá acho que tem toda essa questão, uma identidade negra, um ser humano negro que é capaz de se apropriar de um território, que é a questão da geografia, que através da palavra ele exerce uma influencia na cultura geográfica. Isso eu acho excepcional

Edson: Ele foi dar aulas em Paris. Ele fala que deu aula na Sorbonne, eu falei a do Fernando Henrique?

Prof. Artur Matuck: Na terra era bem importante.

Edson: Na periferia, não é? Periferia de Paris, mas é periferia. 
Prof. Artur Matuck: Bom, tem mais algumas perguntas?

Thaís: Essa foi a ultima pergunta. Você tem alguma pergunta Edson?

Edson: Não, acho que está bom.

Prof. Artur Matuck: Você! Faz uma pergunta para a gente.

Edson: Acho que ela podia falar dessa vivencia que ela teve com os xavantes.

Renata: Off câmera? Não sei exatamente o que você quer que eu fale.

Edson: Eles vieram de sangradouro para fazer uma gravação aqui?

Renata: Eles fizeram a gravação lá, eles escolhem a temática, eles organizam o que eles querem apresentar, discutir, documentar, eles trazem esse material para cá, eles já começaram a edição lá, eles trouxeram para cá para continuar essa edição, eles não são só xavantes eles são xavantes e bororo, e nisso saíram cinco vídeos que ainda estão em fase final mesmo, finalização total, um sobre alcoolismo, outro sobre diabete, um outro sobre um espaço bororo que chama Jarudori, que era um espaço que inicialmente foi demarcado em 39, 100 mil hectares no Mato Grosso para esses bororos e ai até 60 e alguma coisa reduziu a quantidade de terra para 4 mil hectares e mais recentemente para 10 hectares e eles estão tentando retomar os 4 mil.

Edson: É porque eles dividem essa reserve indígena que o Hiparidi é originário, eles dividem com os bororo. Só que o xavante é um povo guerreiro e o bororos foram se encolhendo.

Renata: E nômade. E os bororo não. O xavante é nômade e os bororo não. $E$ parte dos rituais deles e dos espaços deles tem a ver com essa área. Essa área enfim, foi tomada e até eles estão falando sobre, e até encontrei até artigos sobre isso, como essa área foi doada ou está sob posse de um cunhado de um representante da 
FUNAI local, e é um cara que trabalha com soja. Nessa área agora. O que você estava dizendo com a língua aconteceu a mesma coisa com os bororos.

Edson: E a questão do alcoolismo, o que foi levantado?

Renata: Não eles estão colocando como um problema pra ser discutido dentro da aldeia. 
Tratado de Amizade, Cooperação e Consulta entre a

República Federativa do Brasil e a República Portuguesa

Presidência da República

Casa Civil

Subchefia para Assuntos Jurídicos

\title{
DECRETO N 3.927, DE 19 DE SETEMBRO DE 2001.
}

\begin{abstract}
Promulga o Tratado de Amizade, Cooperação e Consulta, entre a República Federativa do Brasil e a República Portuguesa, celebrado em Porto Seguro em 22 de abril de 2000.
\end{abstract}

O PRESIDENTE DA REPÚBLICA, no uso da atribuição que the confere o art. 84, inciso VIII, da Constituição,

Considerando que os Governos da República Federativa do Brasil e da República Portuguesa celebraram, em Porto Seguro, em 22 de abril de 2000, Tratado de Amizade, Cooperação e Consulta;

Considerando que o Congresso Nacional aprovou esse Acordo por meio do Decreto Legislativo no 165 , de 30 de maio de 2001;

Considerando que o Tratado entrou em vigor em 5 de setembro de 2001;

\section{DECRETA:}

Art. 1ㅇ $\mathrm{O}$ Tratado de Amizade, Cooperação e Consulta entre a República Federativa do Brasil e a República Portuguesa, celebrado em Porto Seguro, em 22 de abril de 2001, apenso por cópia ao presente Decreto, será executado e cumprido tão inteiramente como nele se contém.

Art. $2^{\circ}$ São sujeitos à aprovação do Congresso Nacional quaisquer atos que possam resultar em revisão do referido Tratado, bem como quaisquer ajustes complementares que, nos termos do art. 49, inciso I, da Constituição Federal, acarretem encargos ou compromissos gravosos ao patrimônio nacional.

Art. $3^{\circ}$ Este Decreto entra em vigor na data de sua publicação.

Brasília, 19 de setembro de 2001; $180^{\circ}$ da Independência e $113^{\circ}$ da República.

FERNANDO HENRIQUE CARDOSO

Luiz Felipe de Seixas Corrêa 
Tratado de Amizade, Cooperação e Consulta entre a República Federativa do Brasil e a República Portuguesa.

O Governo da República Federativa do Brasil

e

O Governo da República Portuguesa

(adiante denominados "Partes Contratantes"),

Representados pelo Ministro de Estado das Relações Exteriores do Brasil e pelo Ministro dos Negócios Estrangeiros de Portugal, reunidos em Porto Seguro, em 22 de abril de 2000;

Considerando que nesse dia se comemora o quinto centenário do fato histórico do descobrimento do Brasil;

Conscientes do amplo campo de convergência de objetivos e da necessidade de reafirmar, consolidar e desenvolver os particulares e fortes laços que unem os dois povos, fruto de uma história partilhada por mais de três séculos e que exprimem uma profunda comunidade de interesses morais, políticos, culturais, sociais e econômicos;

Reconhecendo a importância de instrumentos similares que precederam o presente Tratado,

Acordam o seguinte:

Título I

Princípios Fundamentais

1. Fundamentos e Objetivos do Tratado

Artigo $1^{\circ}$

As Partes Contratantes, tendo em mente a secular amizade que existe entre os dois países, concordam em que suas relações terão por base os seguintes princípios e objetivos:

1. o desenvolvimento econômico, social e cultural alicerçado no respeito os direitos e liberdades fundamentais, enunciados na Declaração Universal dos Direitos do Homem, no princípio da organização democrática da Sociedade e do Estado, e na busca de uma maior e mais ampla justiça social;

2. o estreitamento dos vínculos entre os dois povos com vistas à garantia da paz e do progresso nas relações internacionais, à luz dos objetivos e princípios consagrados na Carta das Nações Unidas;

3. a consolidação da Comunidade dos Países de Língua Portuguesa, em que Brasil e Portugal se integram, instrumento fundamental na prossecução de interesses comuns; 
4. a participação do Brasil e de Portugal em processos de integração regional, como a União Européia e o Mercosul, almejando permitir a aproximação entre a Europa e a América Latina para a intensificação das suas relações.

Artigo $2^{\circ}$

1. O presente Tratado de Amizade, Cooperação e Consulta define os princípios gerais que hão de reger as relações entre os dois países, à luz dos princípios e objetivos atrás enunciados.

2. No quadro por ele traçado, outros instrumentos jurídicos bilaterais, já concluídos ou a concluir, são ou poderão ser chamados a desenvolver ou regulamentar áreas setoriais determinadas.

2. Cooperação Política e Estruturas Básicas de

Consulta e Cooperação

Artigo $3^{\circ}$

Em ordem a consolidar os laços de amizade e de cooperação entre as Partes Contratantes, serão intensificadas a consulta e a cooperação política sobre questões bilaterais e multilaterais de interesse comum.

Artigo $4^{\circ}$

A consulta e a cooperação política entre as Partes Contratantes terão como instrumentos:

a) visitas regulares dos Presidentes dos dois países;

b) cimeiras anuais dos dois Governos, presididas pelos chefes dos respectivos Executivos;

c) reuniões dos responsáveis pela política externa de ambos os países, a realizar, em cada ano, alternadamente, no Brasil e em Portugal, bem como, sempre que recomendável, no quadro de organizações internacionais, de caráter universal ou regional, em que os dois Estados participem;

d) visitas recíprocas dos membros dos poderes constituídos de ambos os países, para além das referidas nas alíneas anteriores, com especial incidência naquelas que contribuam para o reforço da cooperação interparlamentar;

e) reuniões de consulta política entre altos funcionários do Ministério das Relações Exteriores do Brasil e do Ministério dos Negócios Estrangeiros de Portugal;

f) reuniões da Comissão Permanente criada por este Tratado ao abrigo do Artigo 69. 
Artigo $5^{\circ}$

A consulta e a cooperação nos domínios cultural e científico, econômico e financeiro e em outros domínios específicos processar-se-ão através dos mecanismos para tanto previstos no presente Tratado e nos acordos setoriais relativos a essas áreas.

Título II

Dos Brasileiros em Portugal e dos Portugueses no Brasil Brasil

1. Entrada e Permanência de Brasileiros em Portugal e de Portugueses no

Artigo $6^{\circ}$

Os titulares de passaportes diplomáticos, especiais, oficiais ou de serviço válidos do Brasil ou de Portugal poderão entrar no território da outra Parte Contratante ou dela sair sem necessidade de qualquer visto.

Artigo $7^{\circ}$

1. Os titulares de passaportes comuns válidos do Brasil ou de Portugal que desejem entrar no território da outra Parte Contratante para fins culturais, empresariais, jornalísticos ou turísticos por período de até 90 (noventa) dias são isentos de visto.

2. O prazo referido no parágrafo $1^{\circ}$ poderá ser prorrogado segundo a legislação imigratória de cada um dos países, por um período máximo de 90 (noventa) dias.

Artigo $8^{\circ}$

A isenção de vistos estabelecida no Artigo anterior não exime os seus beneficiários da observância das leis e regulamentos em vigor, concernentes à entrada e permanência de estrangeiros no país de ingresso.

Artigo $9^{\circ}$

É vedado aos beneficiários do regime de isenção de vistos estabelecido no Artigo 6o o exercício de atividades profissionais cuja remuneração provenha de fonte pagadora situada no país de ingresso.

Artigo 10

As Partes Contratantes trocarão exemplares dos seus passaportes em caso de mudança dos referidos modelos.

Artigo 11 
Em regime de reciprocidade, são isentos de toda e qualquer taxa de residência os nacionais de uma das Partes Contratantes residentes no território da outra Parte Contratante.

2. Estatuto de Igualdade entre Brasileiros e Portugueses

Artigo 12

Os brasileiros em Portugal e os portugueses no Brasil, beneficiários do estatuto de igualdade, gozarão dos mesmos direitos e estarão sujeitos aos mesmos deveres dos nacionais desses Estados, nos termos e condições dos Artigos seguintes.

Artigo 13

1. A titularidade do estatuto de igualdade por brasileiros em Portugal e por portugueses no Brasil não implicará em perda das respectivas nacionalidades.

2. Com a ressalva do disposto no parágrafo $3^{\circ}$ do Artigo 17 , os brasileiros e portugueses referidos no parágrafo $1^{\circ}$ continuarão no exercício de todos os direitos e deveres inerentes às respectivas nacionalidades, salvo aqueles que ofenderem a soberania nacional e a ordem pública do Estado de residência.

Artigo 14

Excetuam-se do regime de equiparação previsto no Artigo 12 os direitos expressamente reservados pela Constituição de cada uma das Partes Contratantes aos seus nacionais.

Artigo 15

O estatuto de igualdade será atribuído mediante decisão do Ministério da Justiça, no Brasil, e do Ministério da Administração Interna, em Portugal, aos brasileiros e portugueses que 0 requeiram, desde que civilmente capazes e com residência habitual no país em que ele é requerido.

Artigo 16

O estatuto de igualdade extinguir-se-á com a perda, pelo beneficiário, da sua nacionalidade ou com a cessação da autorização de permanência no território do Estado de residência.

Artigo 17

1. O gozo de direitos políticos por brasileiros em Portugal e por portugueses no Brasil só será reconhecido aos que tiverem três anos de residência habitual e depende de requerimento à autoridade competente.

2. A igualdade quanto aos direitos políticos não abrange as pessoas que, no Estado da nacionalidade, houverem sido privadas de direitos equivalentes. 
3. O gozo de direitos políticos no Estado de residência importa na suspensão do exercício dos mesmos direitos no Estado da nacionalidade.

\section{Artigo 18}

Os brasileiros e portugueses beneficiários do estatuto de igualdade ficam submetidos à lei penal do Estado de residência nas mesmas condições em que os respectivos nacionais e não estão sujeitos à extradição, salvo se requerida pelo Governo do Estado da nacionalidade.

\section{Artigo 19}

Não poderão prestar serviço militar no Estado de residência os brasileiros e portugueses nas condições do artigo 12. A lei interna de cada Estado regulará, para esse efeito, a situação dos respectivos nacionais.

Artigo 20

O brasileiro ou português, beneficiário do estatuto de igualdade, que se ausentar do território do Estado de residência terá direito à proteção diplomática apenas do Estado da nacionalidade.

Artigo 21

Os Governos do Brasil e de Portugal comunicarão reciprocamente, por via diplomática, a aquisição e perda do estatuto de igualdade regulado no presente Tratado.

Artigo 22

Aos brasileiros em Portugal e aos portugueses no Brasil, beneficiários do estatuto de igualdade, serão fornecidos, para uso interno, documentos de identidade de modelos iguais aos dos respectivos nacionais, com a menção da nacionalidade do portador e referência ao presente Tratado.

Título III

Cooperação Cultural, Científica e Tecnológica

1. Princípios Gerais

Artigo 23

1. Cada Parte Contratante favorecerá a criação e a manutenção, em seu território, de centros e institutos destinados ao estudo, pesquisa e difusão da cultura literária, artística, científica e da tecnologia da outra Parte.

2. Os centros e institutos referidos compreenderão, designadamente, bibliotecas, núcleos de bibliografia e documentação, cinematecas, videotecas e outros meios de informação. 
1. Cada Parte Contratante esforçar-se-á por promover no território da outra Parte o conhecimento do seu patrimônio cultural, nomeadamente através de livros, periódicos e outras publicações, meios audiovisuais e eletrônicos, conferências, concertos, exposições, exibições cinematográficas e teatrais e manifestações artísticas semelhantes, programas radiofônicos e de televisão.

2. À Parte promotora das atividades mencionadas no número ou parágrafo anterior caberá o encargo das despesas delas decorrentes, devendo a Parte em cujo território se realizem as manifestações assegurar toda a assistência e a concessão das facilidades ao seu alcance.

3. A todo o material que fizer parte das referidas manifestações será concedida, para efeito de desembaraço alfandegário, isenção de direitos e demais imposições.

Artigo 25

Com o fim de promover a realização de conferências, estágios, cursos ou pesquisas no território da outra Parte, cada Parte Contratante favorecerá e estimulará o intercâmbio de professores, estudantes, escritores, artistas, cientistas, pesquisadores, técnicos e demais representantes de outras atividades culturais.

Artigo 26

1. Cada Parte Contratante atribuirá anualmente bolsas de estudo a nacionais da outra Parte possuidores de diploma universitário, profissionais liberais, técnicos, cientistas, pesquisadores, escritores e artistas, a fim de aperfeiçoarem seus conhecimentos ou realizarem pesquisas no campo de suas especialidades.

2. As bolsas de estudo deverão ser utilizadas no território da Parte que as tiver concedido.

Artigo 27

1. Cada Parte Contratante promoverá, através de instituições públicas ou privadas, especialmente institutos científicos, sociedades de escritores e artistas, câmaras e institutos de livros, o envio regular de suas publicações e demais meios de difusão cultural com destino às instituições referidas no parágrafo $2^{\circ}$ do Artigo 23.

2. Cada Parte Contratante estimulará a edição, a co-edição e a importação das obras literárias, artísticas, científicas e técnicas de autores nacionais da outra Parte.

3. As Partes Contratantes estimularão entendimentos entre as instituições representativas da indústria do livro, com vista à realização de acordos sobre a tradução de obras estrangeiras para a língua portuguesa e sua edição.

4. As Partes Contratantes organizarão, através de seus serviços competentes, a distribuição coordenada das reedições de obras clássicas e das edições de obras 
originais feitas em seu território, em número suficiente para a divulgação regular das respectivas culturas entre instituições e pessoas interessadas da outra Parte.

Artigo 28

1. As Partes Contratantes comprometem-se a estimular a cooperação nos campos da ciência e da tecnologia.

2. Essa cooperação poderá assumir, nomeadamente, a forma de intercâmbio de informações e de documentação científica, técnica e tecnológica; de intercâmbio de professores, estudantes, cientistas, pesquisadores, peritos e técnicos; de organização de visitas e viagens de estudo de delegações científicas e tecnológicas; de estudo, preparação e realização conjunta ou coordenada de programas ou projetos de pesquisa científica e de desenvolvimento tecnológico; de apoio à realização, no território de uma das Partes, de exposições de caráter científico, tecnológico e industrial, organizadas pela outra Parte Contratante.

Artigo 29

Os conhecimentos tecnológicos adquiridos em conjunto, em virtude da cooperação nos campos da ciência e da tecnologia, concretizados em produtos ou processos que representem invenções, serão considerados propriedade comum e poderão ser patenteados em qualquer das Partes Contratantes, conforme a legislação aplicável.

Artigo 30

As Partes Contratantes propõem-se levar a cabo a microfilmagem ou a inclusão em outros suportes eletrônicos de documentos de interesse para a memória nacional do Brasil e de Portugal existentes nos respectivos arquivos e examinarão em conjunto, quando solicitadas, a possibilidade de participação nesse projeto de países de tradição cultural comum.

Artigo 31

1. Cada Parte Contratante, com o objetivo de desenvolver o intercâmbio entre os dois países no domínio da cinematografia e outros meios audiovisuais, favorecerá a co-produção de filmes, vídeos e outros meios audiovisuais, nos termos dos parágrafos seguintes.

2. Os filmes cinematográficos de longa ou curta metragem realizados em regime de co-produção serão considerados nacionais pelas autoridades competentes dos dois países e gozarão dos benefícios e vantagens que a legislação de cada Parte Contratante assegurar às respectivas produções.

3. Serão definidas em acordo complementar as condições em que se considera co-produção, para os efeitos do parágrafo anterior, a produção conjunta de filmes cinematográficos, por organizações ou empresas dos dois países, bem como os procedimentos a observar na apresentação e realização dos respectivos projetos. 
4. Outras co-produções audiovisuais poderão ser consideradas nacionais pelas autoridades competentes dos dois países e gozar dos benefícios e vantagens que a legislação de cada Parte Contratante assegurar às respectivas produções, em termos a definir em acordo complementar.

2. Cooperação no Domínio da Língua Portuguesa

Artigo 32

As Partes Contratantes, reconhecendo o seu interesse comum na defesa, no enriquecimento e na difusão da língua portuguesa, promoverão, bilateral ou multilateralmente, em especial no quadro da Comunidade dos Países de Língua Portuguesa, a criação de centros conjuntos para a pesquisa da língua comum e colaborarão na sua divulgação internacional, e nesse sentido apoiarão as atividades do Instituto Internacional de Língua Portuguesa, bem como iniciativas privadas similares.

\section{Cooperação no Domínio do Ensino e da Pesquisa}

Artigo 33

As Partes Contratantes favorecerão e estimularão a cooperação entre as respectivas Universidades, instituições de ensino superior, museus, bibliotecas, arquivos, cinematecas, instituições científicas e tecnológicas e demais entidades culturais.

Artigo 34

Cada Parte Contratante promoverá a criação, nas respectivas Universidades, de cátedras dedicadas ao estudo da história, literatura e demais áreas culturais da outra Parte.

Artigo 35

Cada Parte Contratante promoverá a inclusão nos seus programas nacionais, nos vários graus e ramos de ensino, do estudo da literatura, da história, da geografia e das demais áreas culturais da outra Parte.

Artigo 36

As Partes Contratantes procurarão coordenar as atividades dos leitorados do Brasil e de Portugal em outros países.

Artigo 37

Nos termos a definir por acordo complementar, poderão os estudantes brasileiros ou portugueses, inscritos em uma Universidade de uma das Partes Contratantes, ser admitidos a realizar uma parte do seu currículo acadêmico em uma Universidade da outra Parte Contratante. 
Artigo 38

Também em acordo complementar será definido o regime de concessão de equivalência de estudos aos nacionais das Partes Contratantes que tenham tido aproveitamento escolar em estabelecimentos de um desses países, para o efeito de transferência e de prosseguimento de estudos nos estabelecimentos da outra Parte Contratante.

4. Reconhecimento de Graus e Títulos Acadêmicos e de Títulos de Especialização

Artigo 39

1. Os graus e títulos acadêmicos de ensino superior concedidos por estabelecimentos para tal habilitados por uma das Partes Contratantes em favor de nacionais de qualquer delas serão reconhecidos pela outra Parte Contratante, desde que certificados por documentos devidamente legalizados.

2. Para efeitos do disposto no Artigo anterior, consideram-se graus e títulos acadêmicos os que sancionam uma formação de nível pós-secundário com uma duração mínima de três anos.

Artigo 40

A competência para conceder o reconhecimento de um grau ou título acadêmico pertence, no Brasil às Universidades e em Portugal às Universidades e demais instituições de ensino superior, a quem couber atribuir o grau ou título acadêmico correspondente.

Artigo 41

O reconhecimento será sempre concedido, a menos que se demonstre, fundamentadamente, que há diferença substancial entre os conhecimentos e as aptidões atestados pelo grau ou título em questão, relativamente ao grau ou título correspondente no país em que o reconhecimento é requerido.

Artigo 42

1. Podem as Universidades no Brasil e as Universidades e demais instituições de ensino superior em Portugal celebrar convênios tendentes a assegurar o reconhecimento automático dos graus e títulos acadêmicos por elas emitidos em favor dos nacionais de uma e outra Parte Contratante, tendo em vista os currículos dos diferentes cursos por elas ministrados.

2. Tais convênios deverão ser homologados pelas autoridades competentes em cada uma das Partes Contratantes se a legislação local o exigir.

Artigo 43 
Sem prejuízo do que se achar eventualmente disposto quanto a numerus clausus, o acesso a cursos de pós-graduação em Universidades no Brasil e em Universidades e demais instituições de ensino superior em Portugal é facultado aos nacionais da outra Parte Contratante em condições idênticas às exigidas aos nacionais do país da instituição em causa.

Artigo 44

Com as adaptações necessárias, aplica-se por analogia, ao reconhecimento de títulos de especialização, o disposto nos Artigos 39 a 41.

Artigo 45

1. As Universidades no Brasil e as Universidades e demais instituições de ensino superior em Portugal, associações profissionais para tal legalmente habilitadas ou suas federações, bem como as entidades públicas para tanto competentes, de cada uma das Partes Contratantes, poderão celebrar convênios que assegurem o reconhecimento de títulos de especialização por elas emitidos, em favor de nacionais de uma e outra Parte.

2. Tais convênios deverão ser homologados pelas autoridades competentes de ambas as Partes Contratantes, se não tiverem sido por elas subscritos.

\section{Acesso a Profissões e seu Exercício}

\section{Artigo 46}

Os nacionais de uma das Partes Contratantes poderão aceder a uma profissão e exercê-la, no território da outra Parte Contratante, em condições idênticas às exigidas aos nacionais desta última.

\section{Artigo 47}

Se o acesso a uma profissão ou o seu exercício se acharem regulamentados no território de uma das Partes Contratantes por disposições decorrentes da participação desta em um processo de integração regional, poderão os nacionais da outra Parte Contratante aceder naquele território a essa profissão e exercê-la em condições idênticas às prescritas para os nacionais dos outros Estados participantes nesse processo de integração regional.

\section{Direitos de Autor e Direitos Conexos}

Artigo 48

1. Cada Parte Contratante, em harmonia com os compromissos internacionais a que tenham aderido, reconhece e assegura a proteção, no seu território, dos direitos de autor e direitos conexos dos nacionais da outra Parte. 
2. Nos mesmos termos e sempre que verificada a reciprocidade, serão reconhecidos e assegurados os direitos sobre bens informáticos.

3. Será estudada a melhor forma de conceder aos beneficiários do regime definido nos dois parágrafos ou números anteriores tratamento idêntico ao dos nacionais no que toca ao recebimento dos seus direitos.

Título IV

Cooperação Econômica e Financeira

1. Princípios Gerais

Artigo 49

As Partes Contratantes encorajarão e esforçar-se-ão por promover o desenvolvimento e a diversificação das suas relações econômicas e financeiras, mediante uma crescente cooperação, tendente a assegurar a dinamização e a modernização das respectivas economias, sem prejuízo dos compromissos internacionais por elas assumidos.

Artigo 50

Tendo em vista o disposto no Artigo anterior, as Partes Contratantes procurarão definir, relativamente aos diversos setores de atividade, regimes legais que permitam o acesso das pessoas físicas e jurídicas ou pessoas singulares e coletivas nacionais de cada uma delas a um tratamento tendencialmente unitário.

Artigo 51

Reconhecem as Partes que a realização dos objetivos referidos no Artigo 49 requer:

a) a difusão adequada, sistemática e atualizada de informações sobre a capacidade de oferta de bens e de serviços e de tecnologia, bem como de oportunidades de investimentos nos dois países;

b) o acréscimo de colaboração entre empresas brasileiras e portuguesas, através de acordos de cooperação, de associação e outros que concorram para o seu crescimento e progresso técnico e facilitem o aumento e a valorização do fluxo de trocas entre os dois países;

c) a promoção e realização de projetos comuns de investimentos, de coinvestimento e de transferência de tecnologia com vistas a desenvolver e modernizar as estruturas empresariais no Brasil e em Portugal e facilitar o acesso a novas atividades em termos competitivos no plano internacional.

Artigo 52 
Para alcançar os objetivos assinalados nos Artigos anteriores propõem-se as Partes, designadamente:

a) estimular a troca de informações e de experiências bem como a realização de estudos e projetos conjuntos de pesquisa e de planejamento ou planeamento entre instituições, empresas e suas organizações, de cada um dos países, em ordem a permitir a elaboração de estratégias de desenvolvimento comum, nos diferentes ramos de atividade econômica, a médio ou a longo prazo;

b) promover ou desenvolver ações conjuntas no domínio da formação científica, profissional e técnica dos intervenientes em atividades econômicas e financeiras nos dois países;

c) fomentar a cooperação entre empresas brasileiras e portuguesas na realização de projetos comuns de investimento tanto no Brasil e em Portugal como em terceiros mercados, designadamente através da constituição de "joint-ventures", privilegiando as áreas de integração econômica em que os dois países se enquadram;

d) estabelecer o intercâmbio sistemático de informações sobre concursos públicos ou concorrências públicas nacionais e internacionais e facilitar o acesso dos agentes econômicos brasileiros e portugueses a essas informações;

e) concertar as suas posições em instituições internacionais nas áreas econômicas e financeiras, nomeadamente no que respeita à disciplina dos mercados de matérias primas e estabilização de preços.

\section{Artigo 53}

Entre os domínios abertos à cooperação entre as duas Partes, nos termos e com os objetivos fixados nos artigos 49 a 52, figuram designadamente, agricultura, as pescas, energia, indústria, transportes, comunicações e turismo, em conformidade com acordos setoriais complementares.

\section{Cooperação no Domínio Comercial}

\section{Artigo 54}

As Partes Contratantes tomarão as medidas necessárias para promover o crescimento e a diversificação do intercâmbio comercial entre os dois países e, sem quebra dos compromissos internacionais a que ambas se encontram obrigadas, instituirão o melhor tratamento possível aos produtos comerciais com interesse no comércio luso-brasileiro.

\section{Artigo 55}

As Partes Contratantes concederão entre si todas as facilidades necessárias para a realização de exposições, feiras ou certames semelhantes, comerciais, industriais, agrícolas e artesanais, nomeadamente o benefício de importação temporária, a dispensa do pagamento dos direitos de importação para mostruários e 
material de propaganda e, de um modo geral, a simplificação das formalidades aduaneiras, nos termos e condições previstos nas respectivas legislações internas.

3. Cooperação no Domínio dos Investimentos

Artigo 56

1. Cada Parte Contratante promoverá a realização no seu território de investimentos de pessoas físicas e jurídicas ou pessoas singulares e coletivas da outra Parte Contratante.

2. Os investimentos serão autorizados pelas Partes Contratantes de acordo com sua lei interna.

Artigo 57

1. Cada Parte Contratante garantirá, em seu território, tratamento nãodiscriminatório, justo e eqüitativo aos investimentos realizados por pessoas físicas e jurídicas ou pessoas singulares e coletivas da outra Parte Contratante, bem como à livre transferência das importâncias com eles relacionadas.

2. O tratamento referido no parágrafo 1ํ deste Artigo não será menos favorável do que o outorgado por uma Parte Contratante aos investimentos realizados em seu território, em condições semelhantes, por investidores de um terceiro país, salvo aquele concedido em virtude de participação em processos de integração regional, de acordos para evitar a dupla tributação ou de qualquer outro ajuste em matéria tributária.

3. Cada Parte Contratante concederá aos investimentos de pessoas físicas e jurídicas ou pessoas singulares e coletivas da outra Parte tratamento não menos favorável que o dado aos investimentos de seus nacionais, exceto nos casos previstos pelas respectivas legislações nacionais.

\section{Cooperação no Domínio Financeiro e Fiscal}

\section{Artigo 58}

As Partes Contratantes poderão estimular as instituições e organizações financeiras sediadas nos seus territórios a concluírem acordos inter-bancários e concederem créditos preferenciais, tendo em conta a legislação vigente nos dois Países e os respectivos compromissos internacionais, com vista a facilitar a implementação de projetos de cooperação econômica bilateral.

Artigo 59

1. Cada Parte Contratante atuará com base no princípio da não- discriminação em matéria fiscal relativamente aos nacionais da outra Parte. 
2. As Partes Contratantes desenvolverão laços de cooperação no domínio fiscal, designadamente através da adoção de instrumentos adequados para evitar a dupla tributação e a evasão fiscais.

5. Propriedade Industrial e Concorrência Desleal

Artigo 60

Cada Parte Contratante, em harmonia com os compromissos internacionais a que tenha aderido, reconhece e assegura a proteção, no seu território, dos direitos de propriedade industrial dos nacionais da outra Parte, garantindo a estes os recursos aos meios de repressão da concorrência desleal.

Título V

Cooperação em Outras Áreas

1. Meio Ambiente e Ordenamento do Território

Artigo 61

As Partes Contratantes comprometem-se a cooperar no tratamento adequado dos problemas relacionados com a defesa do meio ambiente, no quadro do desenvolvimento sustentável de ambos os países, designadamente quanto ao planejamento ou planeamento e gestão de reservas e parques nacionais, bem como quanto à formação em matéria ambiental.

2. Seguridade Social ou Segurança Social

Artigo 62

As Partes Contratantes darão continuidade e desenvolverão a cooperação no domínio da seguridade social ou segurança social, a partir dos acordos setoriais vigentes.

3. Saúde

Artigo 63

As Partes Contratantes desenvolverão ações de cooperação, designadamente na organização dos cuidados de saúde primários e diferenciados e no controle de endemias e afirmam o seu interesse em uma crescente cooperação em organizações internacionais na área da saúde.

\section{Justiça}

Artigo 64 
1. As Partes Contratantes comprometem-se a prestar auxílio mútuo em matéria penal e a combater a produção e o tráfico ilícito de drogas e substâncias psicotrópicas.

2. Propõem-se também desenvolver a cooperação em matéria de extradição e definir um quadro normativo adequado que permita a transferência de pessoas condenadas para cumprimento de pena no país de origem, bem como alargar ações conjuntas no campo da administração da justiça.

\section{Forças Armadas}

\section{Artigo 65}

As Partes Contratantes desenvolverão a cooperação militar no domínio da defesa, designadamente através de troca de informações e experiências em temas de atualidade como, entre outros, as Operações de Paz das Nações Unidas.

\section{Administração Pública}

\section{Artigo 66}

Através dos organismos competentes e com recurso, se necessário, a instituições e técnicos especializados, as Partes Contratantes desenvolverão a cooperação no âmbito da reforma e modernização administrativa, em temas e áreas entre elas previamente definidos.

\section{Ação Consular}

\section{Artigo 67}

As Partes Contratantes favorecerão contatos ágeis e diretos entre as respectivas administrações na área consular.

\section{Artigo 68}

A partir dos acordos setoriais vigentes, as Partes Contratantes desenvolverão os mecanismos de cooperação baseados na complementaridade das redes consulares dos dois países, de modo a estender a proteção consular aos nacionais de cada uma delas, nos locais a serem previamente especificados entre ambas, onde não exista repartição consular brasileira ou posto consular português.

Título VI

Execução do Tratado

Artigo 69

Será criada uma Comissão Permanente luso-brasileira para acompanhar a execução do presente Tratado. 
Artigo 70

A Comissão Permanente será composta por altos funcionários designados pelo Ministro de Estado das Relações Exteriores do Brasil e pelo Ministro dos Negócios Estrangeiros de Portugal, em número não superior a cinco por cada Parte Contratante.

\section{Artigo 71}

A presidência da Comissão Permanente será assumida, em cada ano, alternadamente, pelo chefe da delegação do Brasil e pelo chefe da delegação de Portugal.

Artigo 72

A Comissão Permanente reunir-se-á obrigatoriamente, uma vez por ano, no país do presidente em exercício e poderá ser convocada por iniciativa deste ou a pedido do chefe da delegação da outra Parte, sempre que as circunstâncias o aconselharem.

Artigo 73

Compete à Comissão Permanente acompanhar a execução do presente Tratado, analisar as dificuldades ou divergências surgidas na sua interpretação ou aplicação, propor as medidas adequadas para a solução dessas dificuldades, bem como sugerir as modificações tendentes a aperfeiçoar a realização dos objetivos deste instrumento.

Artigo 74

1. A Comissão Permanente poderá funcionar em pleno ou em subcomissões para a análise de questões relativas a áreas específicas.

2. As propostas das subcomissões serão submetidas ao plenário da Comissão Permanente.

Artigo 75

As dificuldades ou divergências surgidas na interpretação ou aplicação do Tratado serão resolvidas através de consultas, por negociação direta ou por qualquer outro meio diplomático acordado por ambas as Partes.

Artigo 76

A composição das delegações que participam nas reuniões da Comissão Permanente, ou das suas subcomissões, bem como a data, local e respectiva ordem de trabalhos serão estabelecidos por via diplomática.

Título VII 


\section{Disposições Finais}

\section{Artigo 77}

1. O presente Tratado entrará em vigor trinta dias após a data da recepção da segunda das notas pelas quais as Partes comunicarem reciprocamente a aprovação do mesmo, em conformidade com os respectivos processos constitucionais.

2. O presente Tratado poderá, de comum acordo entre as Partes Contratantes, ser emendado. As emendas entrarão em vigor nos termos do parágrafo $1 \stackrel{0}{ }$.

3. Qualquer das Partes Contratantes poderá denunciar o presente Tratado, cessando os seus efeitos seis meses após o recebimento da notificação de denúncia.

Artigo 78 bilaterais:

O presente Tratado revoga ou ab-roga os seguintes instrumentos jurídicos

a) Acordo entre os Estados Unidos do Brasil e Portugal para a Supressão de Vistos em Passaportes Diplomáticos e Especiais, celebrado em Lisboa, aos 15 dias do mês de outubro de 1951, por troca de Notas;

b) Tratado de Amizade e Consulta entre o Brasil e Portugal, celebrado no Rio de Janeiro, aos 16 dias do mês de novembro de 1953;

c) Acordo sobre Vistos em Passaportes Comuns entre o Brasil e Portugal, concluído em Lisboa, por troca de Notas, aos 9 dias do mês de agosto de 1960;

d) Acordo Cultural entre o Brasil e Portugal, celebrado em Lisboa, aos 7 dias do mês de setembro de 1966;

e) Protocolo Adicional ao Acordo Cultural de 7 de setembro de 1966, celebrado em Lisboa, aos 22 dias do mês de abril de 1971;

f) Convenção sobre Igualdade de Direitos e Deveres entre Brasileiros e Portugueses, celebrada em Brasília, aos 7 dias do mês de setembro de 1971;

g) Acordo, por troca de Notas, entre o Brasil e Portugal, para a abolição do pagamento da taxa de residência pelos nacionais de cada um dos países residentes no território do outro, celebrado em Brasília, aos 17 dias do mês de julho de 1979;

h) Acordo Quadro de Cooperação entre o Governo da República Federativa do Brasil e o Governo da República Portuguesa, celebrado em Brasília, aos 7 dias do mês de maio de 1991;

i) Acordo entre o Governo da República Federativa do Brasil e o Governo da República Portuguesa relativo à Isenção de Vistos, celebrado em Brasília, aos 15 dias do mês de abril de 1996. 
Artigo 79

Os instrumentos jurídicos bilaterais não expressamente referidos no Artigo anterior permanecerão em vigor em tudo o que não for contrariado pelo presente Tratado.

Feito em Porto Seguro, aos 22 dias do mês de abril do ano 2000, em dois exemplares originais em língua portuguesa, sendo ambos igualmente autênticos.

\author{
Pelo Governo da República Federativa do Brasil \\ Luiz Felipe Lampreia \\ Ministro de Estado das Relações Exteriores \\ Pelo Governo da República Portuguesa \\ Jaime Gama \\ Ministro dos Negócios Estrangeiros
}

Fonte: http://www.planalto.gov.br/ccivil 03/decreto/2001/D3927.htm - acesso em 30 de abril de 2013. 